\title{
Aquatic invertebrates and waterbirds of wetlands and rivers of the southern Carnarvon Basin, Western Australia
}

\author{
S.A. Halse ${ }^{1}$, R.J. Shiel ${ }^{2}$, A.W. Storey ${ }^{3}$, D.H.D. Edward ${ }^{3}$, I. Lansbury ${ }^{4}$, D.J. Cale ${ }^{3}$ and M.S. Harvey ${ }^{5}$ \\ ${ }^{1}$ Department of Conservation and Land Management, Wildlife Research Centre, \\ PO Box 51, Wanneroo, Western Australia 6946, Australia \\ ${ }^{2} \mathrm{CRC}$ for Freshwater Ecology, Murray-Darling Freshwater Research Centre, \\ PO Box 921, Albury, New South Wales 2640, Australia \\ ${ }^{3}$ Department of Zoology, The University of Western Australia, \\ Nedlands, Western Australia 6907, Australia \\ ${ }^{4}$ Hope Entomological Collections, Oxford University Museum, Parks Road, \\ Oxford OX1 3PW, United Kingdom \\ ${ }^{5}$ Department of Terrestrial Invertebrates, Western Australian Museum, \\ Francis Street, Perth, Western Australia 6000, Australia
}

\begin{abstract}
Fifty-six sites, representing 53 wetlands, were surveyed in the southern Carnarvon Basin in 1994 and 1995 with the aim of documenting the waterbird and aquatic invertebrate fauna of the region. Most sites were surveyed in both winter and summer, although some contained water only one occasion. Altogether 57 waterbird species were recorded, with 29292 waterbirds of 25 species on Lake MacLeod in October 1994. River pools were shown to be relatively important for waterbirds, while many freshwater claypans were little used.

At least 492 species of aquatic invertebrate were collected. The invertebrate fauna was characterized by the low frequency with which taxa occurred: a third of the species were collected at a single site on only one occasion. Patterns of occurrence were not strongly seasonal. Many undescribed species were found and many range extensions were. recorded, reflecting lack of previous aquatic invertebrate work in the region. The level of regional endemicity could not be assessed adequately, although it is probably comparatively low. In terms of their invertebrate fauna, five types of wetlands were distinguished: river pools, rock pools and larger flowing streams; seeps, springs and smaller creeks; freshwater claypans; birridas; and Lake MacLeod. Environmental factors to which invertebrates appeared to respond were ratio of calcium/alkalinity, total dissolved solids, turbidity, colour, flow, longitude and nutrients, although some factors were inter-correlated.

Additional surveys should find extra species of waterbird and, more particularly, aquatic invertebrate using wetlands of the southern Carnarvon Basin. For many invertebrates, occurrences are too sparse for effective protection of species within a nature reserve system and other mechanisms will be required to ensure their conservation. Comparison of site classifications based on waterbird, aquatic invertebrate and plant data (Gibson et al., 2000) showed patterns among sites identified using one element of the biota did not reflect patterns shown by other elements. This suggests that, until further work has identified an element that reflects the whole wetland community, as many biotic elements as possible should be surveyed.
\end{abstract}

\section{INTRODUCTION}

The southern Carnarvon Basin is located on the mid-west coast of Western Australia, in an area with arid or semi-arid climate. The region contains few nature reserves or national parks, although Shark Bay, in the centre of the region, is a World Heritage area (Anonymous 1995). In 1994, Environment Australia commissioned a comprehensive biological survey of the Basin, including its vegetation, mammals, birds, amphibians, terrestrial arthropods and aquatic fauna (Burbidge et al., 2000).
Beginning with the extensive records of Tom Carter, many casual observations have been made of waterbirds in the southern Carnarvon Basin and a number of small surveys undertaken (Johnstone et al., 2000). Despite waterbirds probably being the most studied faunal group in the Basin, these historical data reveal only broad patterns of waterbird occurrence and some of the more important wetlands for waterbirds. They do not allow easy comparison of different wetlands. For aquatic invertebrates, even broad patterns of 


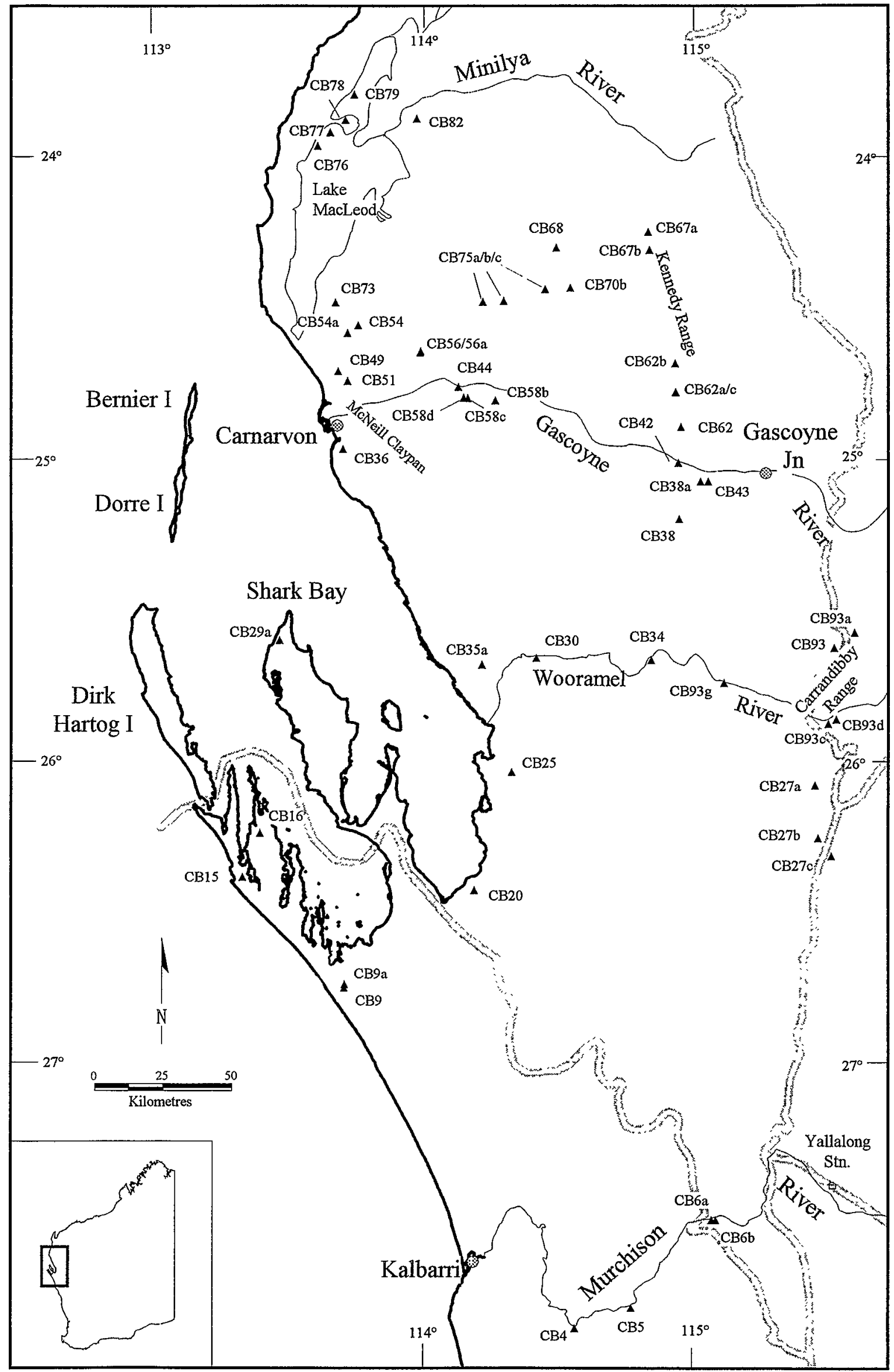

Figure 1 Map of the survey area and boundary of the southern Carnarvon Basin, showing the distribution of the aquatic sampling sites and places mentioned in text. See Appendix 1 for site codes. 
occurrence are unknown because studies have been restricted to a few collections of particular groups for taxonomic purposes (e.g. Lansbury, 1969; De Deckker, 1978).

This lack of biological data is hampering assessment of conservation priorities. Other than parts of Shark Bay, only two wetlands in the southern Carnarvon Basin were identified as nationally significant in a recent review, namely Lake MacLeod and McNeil Claypan (Lane et al., 1996) (Figure 1). Both are large claypans. Lake MacLeod receives marine groundwater, which upwells $20 \mathrm{~km}$ inland in sinkholes on the western side of the lake, as well as surface inflow via the Minilya River, smaller creeks and sheet flow from the Gascoyne River after very heavy rain. It has been shown to support very high numbers of waterbirds, especially migratory shorebirds (Smith and Johnstone, 1985; Jaensch and Vervest, 1990), as well as containing some of the few inland stands of mangroves in Western Australia. The values of McNeil Claypan are less well documented but it fills when the Gascoyne River floods and contains one of the more extensive Muehlenbaeckia/ Sesbania shrublands in north-western Australia, as well as supporting a diversity of waterbirds, including freshwater crakes, rails and shorebirds (Lane et al., 1996).

The southern Carnarvon Basin contains a much greater array of wetland types than are represented by Lake MacLeod and McNeil Claypan. The aims of this survey were (1) to inventory the waterbird and aquatic invertebrate fauna of the Basin, (2) to identify the major wetland types and faunal assemblages occurring in the region, (3) to relate the occurrences of these faunal assemblages to physical and chemical characteristics of waterbodies, and (4) to examine whether the biological community at each wetland may be characterized by surveying a single element of the biota. Fish, amphibians and tortoises were not included in the survey, although they occur commonly in the Basin.

Implications of the data collected, in terms of adequacy of existing nature reserves and formulation of a nature conservation strategy for the Carnarvon Basin, are dealt with by McKenzie et al. (2000).

\section{STUDY AREA AND METHODS}

\section{Study Area}

The area in which wetlands were surveyed extended from the Murchison River in the south to the Minilya River in the north and inland to Gascoyne Junction, covering all but the northern portion of the Carnarvon Basin (Figure 1). The physical environment is described by Wyrwoll et al. (2000). Essentially, the Basin contains low gradient alluvial plains that are traversed by the Murchison,
Table 1 Winter and summer rainfall $(\mathrm{mm})$ associated with sampling periods in the southern Carnarvon Basin (see Table 2 for sampling dates). Long-term median values are shown in parentheses (data from Bureau of Meteorology).

\begin{tabular}{lccc}
\hline & $\begin{array}{c}\text { Winter } \\
\mathbf{1 9 9 4}\end{array}$ & $\begin{array}{c}\text { Summer } \\
\mathbf{1 9 9 5}\end{array}$ & $\begin{array}{c}\text { Winter } \\
\mathbf{1 9 9 5}\end{array}$ \\
\hline Carnarvon & $73(82)$ & $56(11)$ & $123(82)$ \\
Gascoyne Junction & $39(47)$ & $109(29)$ & $56(47)$ \\
Kalbarri & $186(204)$ & $2(5)$ & $173(204)$ \\
\hline
\end{tabular}

Wooramel, Gascoyne and Minilya Rivers. The southernmost part of the Basin has a semi-arid climate with predominantly winter rainfall (Gentilli, 1972). North of Shark Bay, tropical systems influence rainfall patterns and result in significant summer precipitation in more inland areas, which are arid. Median annual rainfall is $379 \mathrm{~mm}$ at Kalbarri, $230 \mathrm{~mm}$ at Yallalong station, $206 \mathrm{~mm}$ at Carnarvon and $190 \mathrm{~mm}$ at Gascoyne Junction (data on rainfall preceding the sampling periods are given in Table 1 and Figure 2) (see Figure 1 for locations).

Major rivers in the Basin flow intermittently, with significant dry intervals being more common in the north. Although flow patterns had not been studied long (8-25 years), data collected prior to 1982 suggested there was significant flow in the Murchison River nearly every year (flood events > 90 per cent of years) (Anonymous 1984). In contrast, flood events occurred on the Minilya River less than every second year. Between flood events, riverbeds dry and surface water recedes to a few pools.

Many sections of river floodplain support extensive networks of intermittently flooded claypans, especially on the Gascoyne River. Intermittently flooded interdunal claypans, often with well-defined lunettes, occur throughout the Basin, although they are less common in the southeast. There are also claypan-like pools on poorly defined watercourses that, it appears, often fill from local rain but form part of the regional drainage system only after exceptional rainfall events. Examples include Coollilee Pool (CB49) and Tirigie Claypan (CB56) in the northern part of the study area (Figure 1). Close to the coast, birridas (evaporite pans) occur in interdunal depressions, especially around Shark Bay. Most of the birridas contain gypsum and, although they may dry intermittently, anecdotal information suggests their water levels show subdued response to oceanic tides. Lake MacLeod, which was open to the sea during the Last Interglacial, is an example of a very large birrida.

Surface water is scarce in the Carnarvon Basin, except after major rainfall events. Permanently 


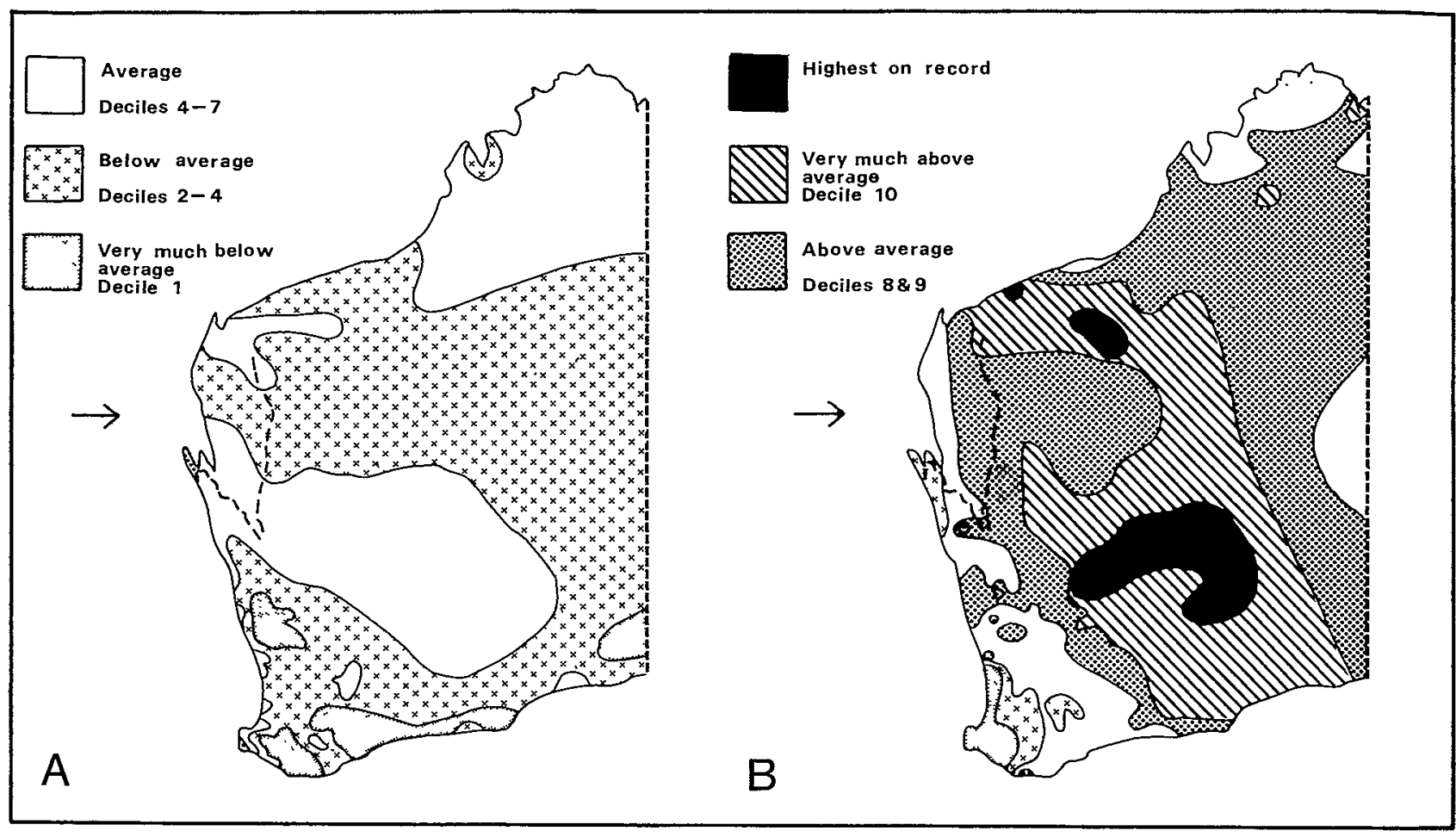

Figure 2 Rainfall deciles in Western Australia in winter 1994 and summer 1995. A. Winter 1994. B. Summer 1995. The arrow indicates the southern Carnarvon Basin. Data from Bureau of Meterology.

flowing water occurs only where there is groundwater discharge at seeps or springs, usually in the headwaters of small creeks associated with the Kennedy and Carrandibby Ranges in the eastern part of the study area. There are no naturally permanent freshwater swamps or claypans; the only sites with moderately deep permanent water are river pools, which are often formed by rocky amphitheatres. There are also a few uncapped artesian bores, which flow constantly, and have formed small artificial swamps. The bore feeding the swamp near Hamelin Station homestead (CB20), the example of this wetland type chosen for survey, was subsequently capped and the swamp has dried.

\section{Site Selection and Sampling}

A total of 56 sites were sampled across the study area, representing 53 wetlands. Lake MacLeod contained four sites (Figure 1). Fifty-three sites were sampled in winter, 37 in summer, and 36 in both winter and summer (Table 2, Appendix 1). Most of the sites were selected during reconnaissance in summer 1994 with the aims of (1) including representatives of all common wetland types in the region, (2) obtaining a geographic spread of wetlands, and (3) as far as possible, sampling wetlands that were in a natural condition. The swamp near Hamelin Station homestead (CB20) was included to examine conservation value of artificial wetlands.

Geographical coordinates of each site were determined using a handheld GPS. Most of the wetlands sampled were comparatively small claypans or swamps $(<5 \mathrm{ha})$, or were river pools, and the sampling area associated with the site effectively covered the whole wetland or river pool. When wetlands were large, the site constituted only a sampling point within the wetland. This was seen most clearly at Lake MacLeod, which has an area of 150,000 ha when fully flooded, and contained four sampling sites (CB76-79) (Figure 1).

On each visit to a site that contained water,

Table 2 Dates of reconnaissance and sampling of wetlands in the southern Carnarvon Basin. See Appendix 1 for explanation of site codes.

\begin{tabular}{llll}
\hline Sampling period & Season & No. of sites & Comments \\
\hline 24-30 April 1994 & reconnaissance & - & Most sites north of Gascoyne River not visited \\
17-30 August 1994 & winter & 47 & \\
11-13 October & winter & 2 & CB78, CB79 and aerial survey of Lake MacLeod \\
15-27 March 1995 & summer & 37 & CB27b, CB30, CB51, CB54a \\
25-27 July 1995 & winter & 4 & C. \\
\hline
\end{tabular}


information was collected about waterbirds, aquatic invertebrates and the wetland environment (mostly water chemistry). Vegetation data were collected separately (Gibson et al., 2000). Binoculars or a telescope were used to identify waterbird species. Where available, waterbird lists from the reconnaissance, as well as two sampling trips, were included in analyses to provide as much information as possible about waterbird use of sites. An aerial survey was made of Lake MacLeod on 12 October 1994 to document waterbird use of the whole lake during a time when palaearctic shorebirds were likely to be present.

Two aquatic invertebrate samples were collected at each site using D-framed pondnets with 250 and $50 \mu \mathrm{m}$ sized meshes. The $250 \mu \mathrm{m}$ sample was collected by $50 \mathrm{~m}$ of vigorous sweeping in all identifiable microhabitats $<1 \mathrm{~m}$ deep at the site, including benthic sediment, submerged and emergent macrophytes, coarse organic material and open water, over a distance of up to $200 \mathrm{~m}$. The 50 $\mu \mathrm{m}$ sample was collected with $50 \mathrm{~m}$ of less vigorous sweeping and included all habitats other than benthos. The $250 \mu \mathrm{m}$ sample was preserved in $70 \%$ alcohol; the $50 \mu \mathrm{m}$ sample was preserved in $1-2 \%$ formaldehyde. Samples were sorted in the laboratory under a dissecting microscope and representative specimens of each taxon were retained for identification. Most animals were identified to species or 'morphospecies' level but Nematoda were identified only to phylum and Polychaeta and some Crustacea with marine affinities were identified only to family. Protozoa were very much under-sampled, although they were identified when collected. Vouchers of most taxa have been retained at the Wildlife Research Centre (Department of Conservation and Land Management), Western Australian Museum or Murray-Darling Freshwater Research Centre. Names of Chironomidae follow Cranston (1994).

Maximum water depth at each site was estimated each sampling occasion and sites were assigned to a flow category (1, lentic; 2 , seasonal river, not flowing when sampled; 3 , spring-fed flowing or seeping water; 4 , flowing river fed by catchment run-off). At each site, water samples and measurements were taken within the area sampled for invertebrates. Conductivity and $\mathrm{pH}$ were measured $15 \mathrm{~cm}$ below the water surface using TPS Models LC81 and LC80A meters; dissolved oxygen was measured near the surface and at the bottom of the water column with a WTW OXI96 meter and the two readings were averaged. Water samples were collected about $15 \mathrm{~cm}$ below the surface for subsequent measurement of total dissolved solids (TDS), ionic composition (including silica in summer), total soluble persulphate nitrogen and phosphorus, chlorophyll, colour and turbidity in the laboratory using standard techniques (APHA,
1989). Samples for nutrient analyses were usually passed through a $0.45 \mu \mathrm{m}$ filter in the field and stored at ambient temperature unless water was very turbid, when they were frozen in the field without filtering and ultracentrifuged in the laboratory. Turbid samples for measurement of TDS were passed through a $0.2 \mu \mathrm{m}$ filter in the laboratory (rather than the standard $0.45 \mu \mathrm{m}$ ) prior to evaporation to minimize contamination by fine particulate matter. At least $200 \mathrm{ml}$ of water was passed through a glass fibre filter paper in the field to obtain a chlorophyll sample for analysis. $\mathrm{MgCO}_{3}$ was added to the algal residue to stabilize chlorophyll, which was frozen until amount of chlorophyll present was determined in the laboratory (APHA, 1989).

Data on ionic composition were converted to milliequivalents $\mathrm{L}^{-1}$ and, to characterize water chemically, ratios of calcium to bicarbonate and carbonate (termed calcium/alkalinity), calcium and magnesium to chloride, and calcium to sulphate were calculated. In total, 14 environmental variables in winter, and 15 in summer, were used in analyses (Appendix 2).

\section{Analyses}

\section{Waterbirds}

Sites were grouped according to similarity of their waterbird fauna using the PATN analysis package (Belbin, 1993) and presence/absence waterbird data. Czekanowski's coefficient was used to measure degree of association between sites after species with a single occurrence and sites with a single species were removed from the dataset. Under-estimated association values $(>0.9)$ were rerecalculated using the Shortest Path option in PATN and the 'Unweighted Pair-Group Mean Average' fusion method, with $\beta=-0.1$, was used to group sites (Sneath and Sokal, 1973). Waterbird species were classified into groups with similar patterns of occurrence using the Two-Step coefficient (Austin and Belbin, 1982) and UPGMA. The discreteness of wetland groups produced by the classifications were examined by ordination using 'Semi-Strong Hybrid Multidimensional Scaling' (Belbin, 1991).

\section{Environmental variables}

Sites were also grouped according to their environmental characteristics. This was done separately for sites sampled in winter and summer. All variables were range-standardized (each value of a variable was divided by the maximum value recorded for that variable) after those with strongly skewed distributions had been log-transformed. The Bray-Curtis association measure and UPGMA fusion method, with $\beta=-0.1$, were used after association measures $>0.95$ were recalculated. 
Differences in environmental characteristics of wetland groups identified using aquatic invertebrate data were examined by one-way ANOVA, using the SAS statistical package (SAS Institute, 1989), after variables with skewed distributions were log-transformed. StudentNewman-Keuls tests were used to identify the groups contributing to significant overall variation in environmental variables.

\section{Aquatic invertebrates}

Sites were grouped on the basis of their invertebrate fauna using presence/absence data and the same methods as for waterbirds. Separate classifications were derived for winter and summer. Association measures $>0.95$ were recalculated. The discreteness of wetland groups produced by the classifications were examined by ordination using SSH. Maximum linear correlations between transformed environmental variables and vectors in ordination space were calculated using the PCC option in PATN after a varimax rotation of the ordination axes (Belbin, 1993). Significance of correlations was determined by Monte Carlo testing (1000 randomisations).

Site classifications based on invertebrates and on environmental variables were compared using a modified Rand statistic (Hubert and Arabie, 1985) (sites $\mathrm{CB} 25$ and $\mathrm{CB} 62 \mathrm{c}$ were omitted from the winter comparison because of incomplete data). Site groupings based on winter and summer invertebrate datasets were also compared after datasets for each season were reduced to a common set of sites.

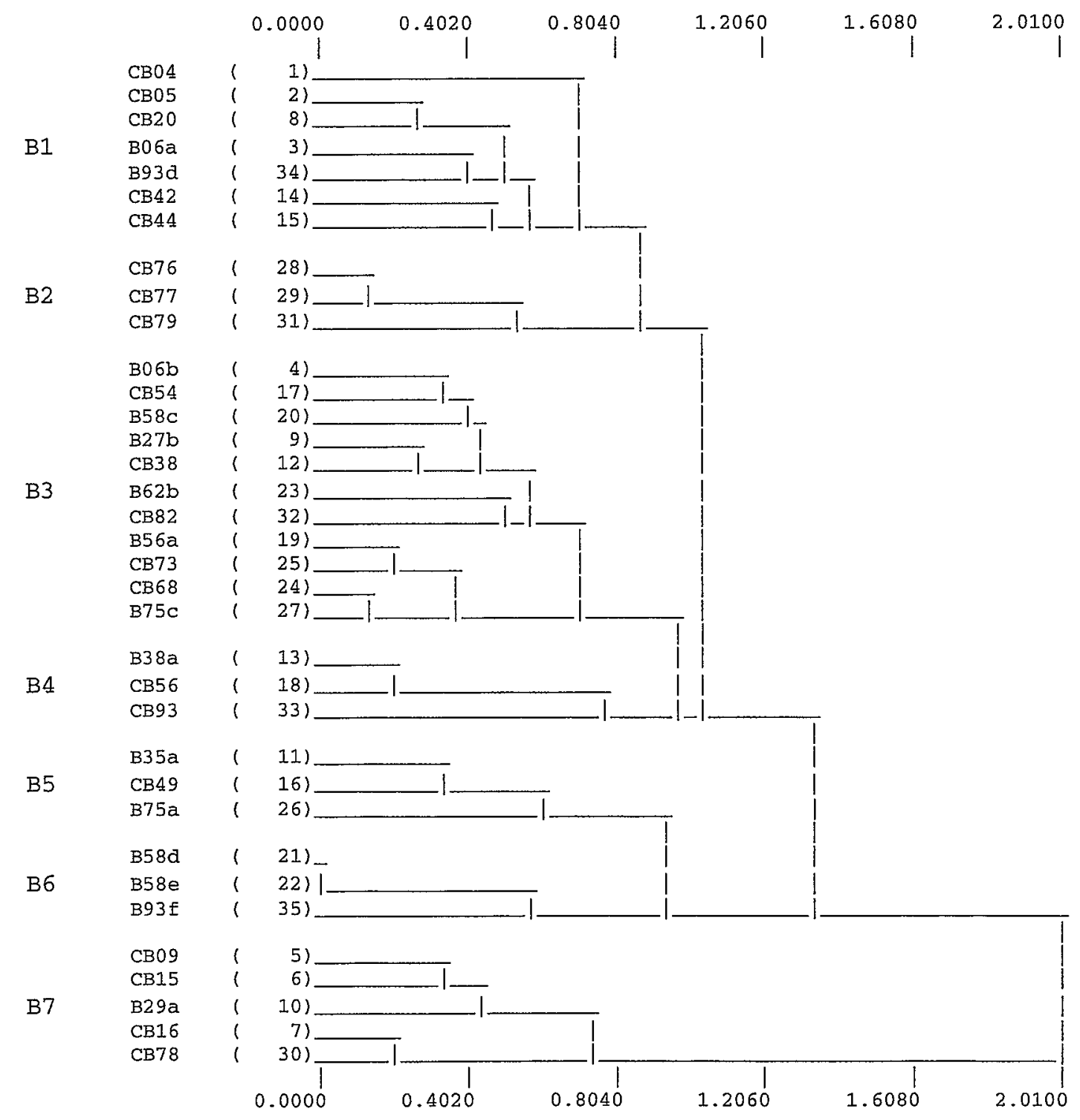

Figure 3 Classification of wetland sites in the southern Carnarvon Basin into seven groups (B1-7) based on waterbird use. See Appendix 1 for site codes. 


\section{RESULTS}

\section{Waterbirds}

A total of 57 species of waterbird were recorded during surveys with the most commonly occurring being White-faced Heron (28 records of one or more birds at a site on a sampling date), Grey Teal (27), White-necked Heron (16), Pacific Black Duck (14), Black Swan (12), Australian Wood Duck (12), Hoary-headed Grebe (12) and Black-fronted Dotterel (12) (Appendix 3). All species recorded are widespread outside the study area (Blakers et al., 1984).

Lake MacLeod (CB76-79) was clearly the wetland supporting greatest numbers of species and individuals during the surveys $(29292$ birds of 25 species in October 1994, including birds counted during an aerial survey of the whole lake). Moderate numbers of birds were recorded on all visits to the bore swamp on Hamelin Station (CB20) (100 birds of 8 species in March 1994; 95 of 12 in August 1994). Lake Julia (CB62b) had 87 birds of 10 species in March 1994. Minilya Pool (CB82) and Winnemia Pool (CB42) were the river pools with most birds ( 87 birds of 10 species and 42 birds of 12 species, respectively, in August 1994). The birrida north of Big Lagoon (CB29a) supported 1285 shorebirds of 4 species in August 1994, making it the birrida with highest waterbird numbers. Waterbirds were not recorded at 11 sites and at another 10 sites only one species occurred. These 21 sites were not included in multivariate analysis (Appendix 3).

Based on waterbird usage, seven groups of sites were identified (Figure 3). Only sites in groups B1 and 2 supported many species, with average species richness of $10.9 \pm 1.3$ and $18.3 \pm 4.9$, respectively. B3 sites showed a considerable range in species richness, with 12 and 10 species, respectively, at CB62b and CB82 but a mean of only $3.9 \pm 0.5$ at other sites. No site in groups B4-7 had more than four species (Appendix 3). In general terms, B1 sites were large river pools or vegetated swamps. B2 consisted of the three wetter Lake MacLeod sites, B3 sites were freshwater claypans, often with some emergent shrub or herbaceous vegetation, as well as the river pool site CB82. Groups B4-6 contained turbid freshwater claypans. B7 consisted of birridas and the driest Lake MacLeod site (CB78). Groups showed moderately clear separation in ordination space (Figure 4).

Seven groups of waterbirds were identified, based on their pattern of occurrence (Figure 5). Groups BIIII contained the more commonly occurring species. Species groups showed only loose relationships with site groupings but BI species occurred most consistently at river pools and vegetated swamps (B1 sites) and were absent from saline sites. Group BII species had the widest occurrence in the study area, occurring in all site groupings, although concentrated at sites of groups B1-3. Group BIII species occurred mostly at the more species-rich and deeper sites (B1 and 2). Group BIV consisted of the Banded Lapwing and Black-tailed Native-hen,

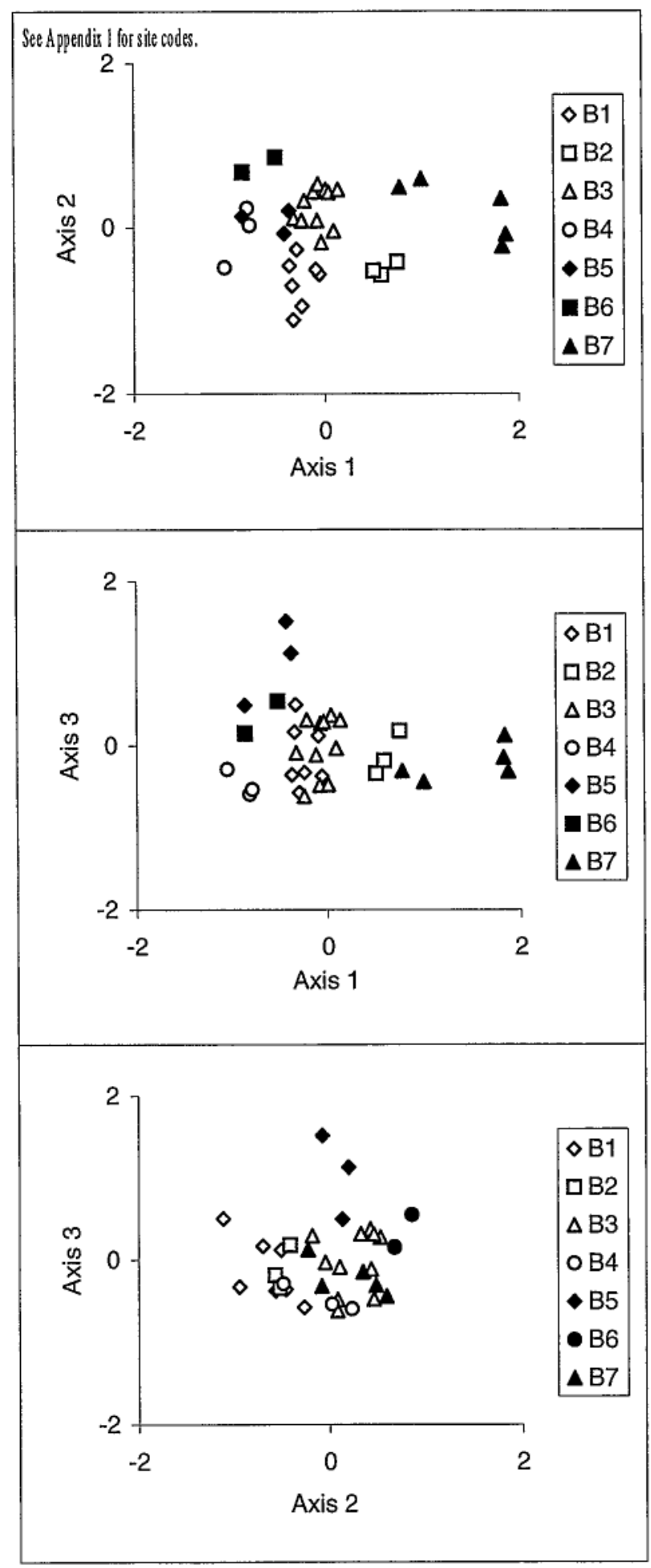

Figure 4 Ordination of wetland sites in the southern Carnarvon Basin based on waterbird use. Wetland groups from Figure 3 are superimposed on ordination (three dimensions, stress $=0.08$ ). 
two relatively terrestrial waterbirds with limited occurrence in the study area. Groups BV and VI consisted of shorebirds, with BV species being restricted to saline Lake MacLeod and birrida sites (B2 and 7), whereas some BVI species were restricted to freshwater and others occurred in fresh as well as salt water and were present in most site groupings. Group BVII contained a mixture of species that occurred at Lake MacLeod; some were roosting in mangroves, others occurred on the water and some were aerial.

\section{Aquatic invertebrate species richness}

At least 492 species of aquatic invertebrate were collected during the surveys (Appendix 4 contains 518 taxa but probably some of these result from the same species being identified at different levels of taxonomic resolution). Fifty per cent of species were microinvertebrates, with many other species (e.g. nematodes, oligochaetes, watermites) also being very small. The major components of fauna richness were rotifers ( $14 \%$ of species), dipterans $(14 \%$, of which well over half were chironomids), cladocerans $(14 \%)$, beetles $(11 \%)$, ostracods $(10 \%)$ and copepods $(9 \%)$. The most frequently recorded taxa were the chironomid species complex Procladius spp. CBT1 (62\% of samples), beetle Eretes australis $(43 \%)$ and chironomid Tanytarsus sp. CBC3 (41\%).

Of the 518 taxa in Appendix 4, 423 were collected during winter, 327 in summer and 232 were common to both seasons. The major cause of
Australasian Grebe Australian Shelduck Australian Wood Duck Black-fronted Dotterel Pacific Black Duck Eurasian coot Great Egret Straw-necked Ibis Yellow-billed Spoonbil1

Grey Teal White-faced Heron

BII Hoary-headed Grebe Pink-eared Duck White-necked Heron

Australian Pelican Darter

BIII Black Swan

Iittle Pied Cormorant Iittle Black Cormorant

BIV Banded Lapwing Black-tailed Native Hen

\section{Banded stilt}

BV Red-capped Plover Curlew sandpiper Red-necked stint

Common Greenshank

BVI Red-kneed Dotterel Common Sandpiper Red-necked Avocet

Black-winged stilt Little Egret Pied Cormorant

BVII Silver GulI Caspian Tern Great Crested Grebe Gull-billed Tern

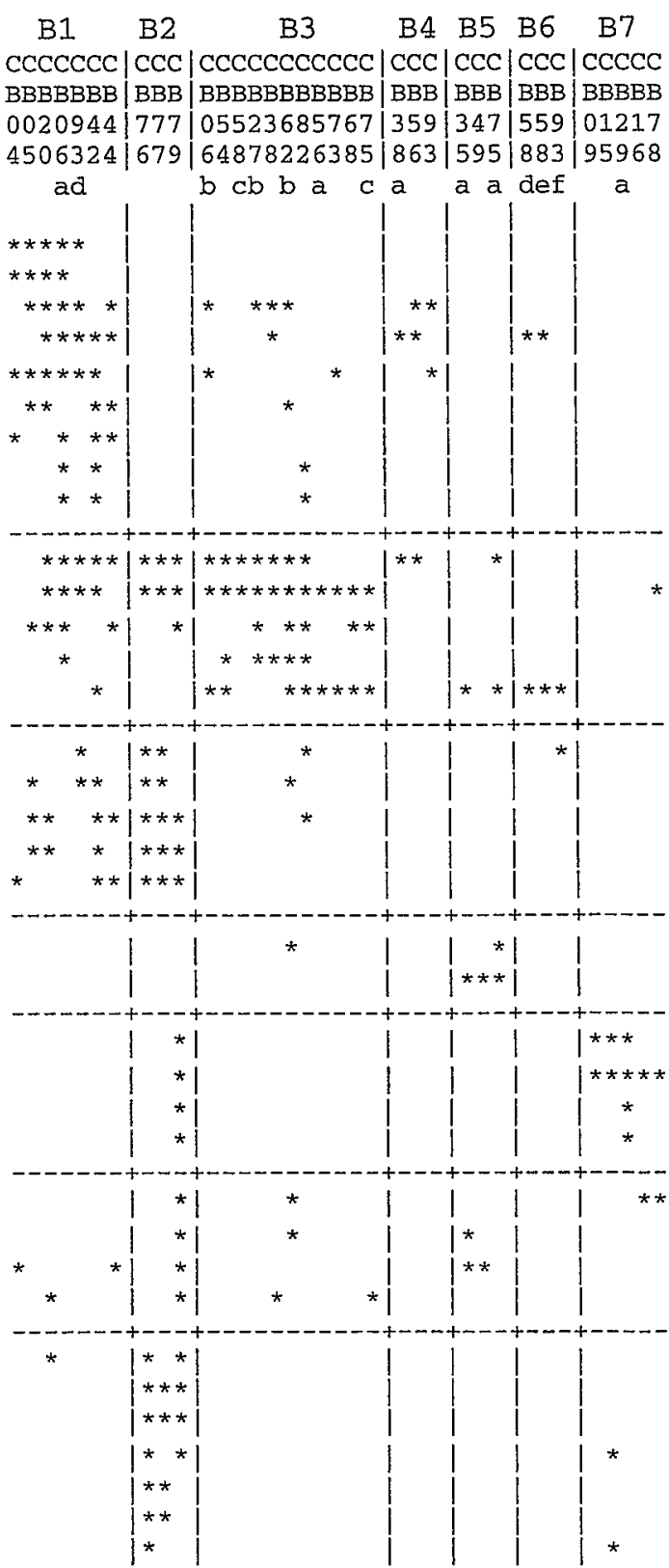

Figure 5 Two-way table of waterbird species groups and wetland site groups in the southern Carnarvon Basin. See Appendix 1 for site codes. 
Table 3 Frequency of occurrence of aquatic invertebrate species from the southern Carnarvon Basin in 90 samples from winter 1994 and summer 1995.

\begin{tabular}{ll}
$\begin{array}{l}\text { No. of samples in } \\
\text { which species occurred }\end{array}$ & No. of species \\
\hline 1 & 158 \\
$2-3$ & 120 \\
$4-6$ & 80 \\
$6-9$ & 44 \\
$10-18$ & 52 \\
$19-27$ & 22 \\
$>27$ & 10 \\
\hline
\end{tabular}

differences in species lists between seasons appeared to be the high proportion of taxa collected infrequently. A third of taxa were recorded only once (although many individuals may have been collected on that occasion) and only 10 species occurred in more than $30 \%$ of samples (Table 3 ). Seasonal preferences were sometimes evident among more common taxa but they did not prevent collection in both seasons; for example, the rotifer Keratella australis had a strong preference for winter (13 out of 14 occurrences) but was recorded once in summer (Appendix 4). The shield shrimp Triops australiensis australiensis showed the opposite pattern, being found at eight of 37 sites in summer and only two of 53 sites in winter. More taxa exhibited preference for winter than summer.

Many new species were collected during the study, including four rotifers, one anostracan, 14 cladocerans (including an undescribed genus), 10 ostracods (including an undescribed genus), four copepods, one hemipteran and two beetles (Table 4). Three named species were recorded in Australia for the first time. The rotifers Hexarthra brandorffi and Proales sigmoidea were previously known from the foothills of the Andes in South America (Koste, 1978) and from Europe and Canada (De Smet, 1996), respectively, and the harpacticoid copepod Robertsonia mourei had been collected only from the Brazilian type locality (Nogueira, 1961). The oligochaete Nais sp. CB1 probably also represents a new record for Australia of a cosmopolitan species (A.M. Pinder, pers. comm.) and collections of the ostracod Zonocypris sp. nov. 466 represent the first time this predominantly African genus has been found in Australia. Identification of the cladocerans Daphnia sp. nov. (aff. barbata) and D. sp. nov. (aff. gibba) requires DNA-typing but both are similar to described African species (C. Wilson, pers. comm.).

Large range extensions within Australia were recorded for many species. At least 27 rotifers previously known from eastern Australia (e.g. Shiel and Koste, 1979) or the Northern Territory (Koste and Shiel, 1983) were recorded in Western Australia for the first time. Several other rotifer taxa that were strongly contracted in preservative remain identified to genus only and the number of range extensions may increase after they have been examined in more detail. About 20 cladoceran species from eastern Australia or the Northern Territory (Smirnov and Timms, 1983; Timms, 1988; Frey, 1991) were recorded from Western Australia for the first time. In many cases the range extensions have considerable conservation significance; for example, Celsinotum hypsilophum was previously

Table 4 Undescribed species of aquatic invertebrate collected to date only from wetlands of the southern Carnarvon Basin in 1994 and 1995.

\section{Rotifera}

Keratella sp. nov. (aff. australis group)

Asplanchna sp. nov. (aff. sieboldi)

Euchlanis sp. nov.

Lecane sp. nov.

\section{Anostraca}

Branchinella sp. nov. (aff. lyrifera) $)^{1}$

\section{Cladocera}

Alonine gen. nov.

Alona spp. nov. A-E

Biapertura sp. nov.

Rak sp. nov.

Macrothrix sp. nov.

Neothrix sp. nov. (aff. superarmata)

Ilyocryptus sp. nov.

Daphnia sp. nov. (aff. barbata)

Daphnia sp. nov. (aff. gibba)

Daphnia sp. nov. (aff. projecta)

\section{Ostracoda}

Paralimnocytherid gen.nov. ${ }^{1}$

Ampullacypris sp. nov. 469

?Ampullacypris sp. nov. 498

Bennelongia sp. nov. $414^{1}$

Cypericercus sp. nov. 415

Cypericercus sp. nov. 422

Cypericercus sp. nov. 444

Heterocypris sp. nov. 489

Mytilocypris sp. nov. 426

Zonocypris sp. nov. $466^{2}$

\section{Calanoida}

Calamoecia halse ${ }^{3}$

Cyclopoida

Mesocyclops sp. nov.

Neocyclops petovskii ${ }^{4}$

\section{Harpacticoida}

Amondaria sp. nov.

\section{Hemiptera}

Plea sp. nov.

\section{Coleoptera}

Paroster sp. nov.

Tiporus sp. nov.

\footnotetext{
${ }^{1}$ Common in Basin

${ }^{2}$ First record of genus in Australia

${ }^{3}$ Described by Bayly (1998)

${ }^{4}$ Described by De Laurentiis et al. (1997)
} 
known only from the Paroo River region of New South Wales (Frey, 1991). Occurrence in the Carnarvon Basin of the calanoid copepod Eudiaptomus lumholtzi, common in northern Australia including the Kimberley (Timms and Morton, 1988), is a $1200 \mathrm{~km}$ southwards extension of the western range of the species. Similarly, records from the Carnarvon Basin extend the range of the anostracan Branchinella probiscida $2000 \mathrm{~km}$ south-westwards (see Geddes, 1981). Menke (1960) recorded the belostomatid hemipteran Lethocerus distictifemur as occurring only in eastern Australia and its collection in this study represents a large range extension.

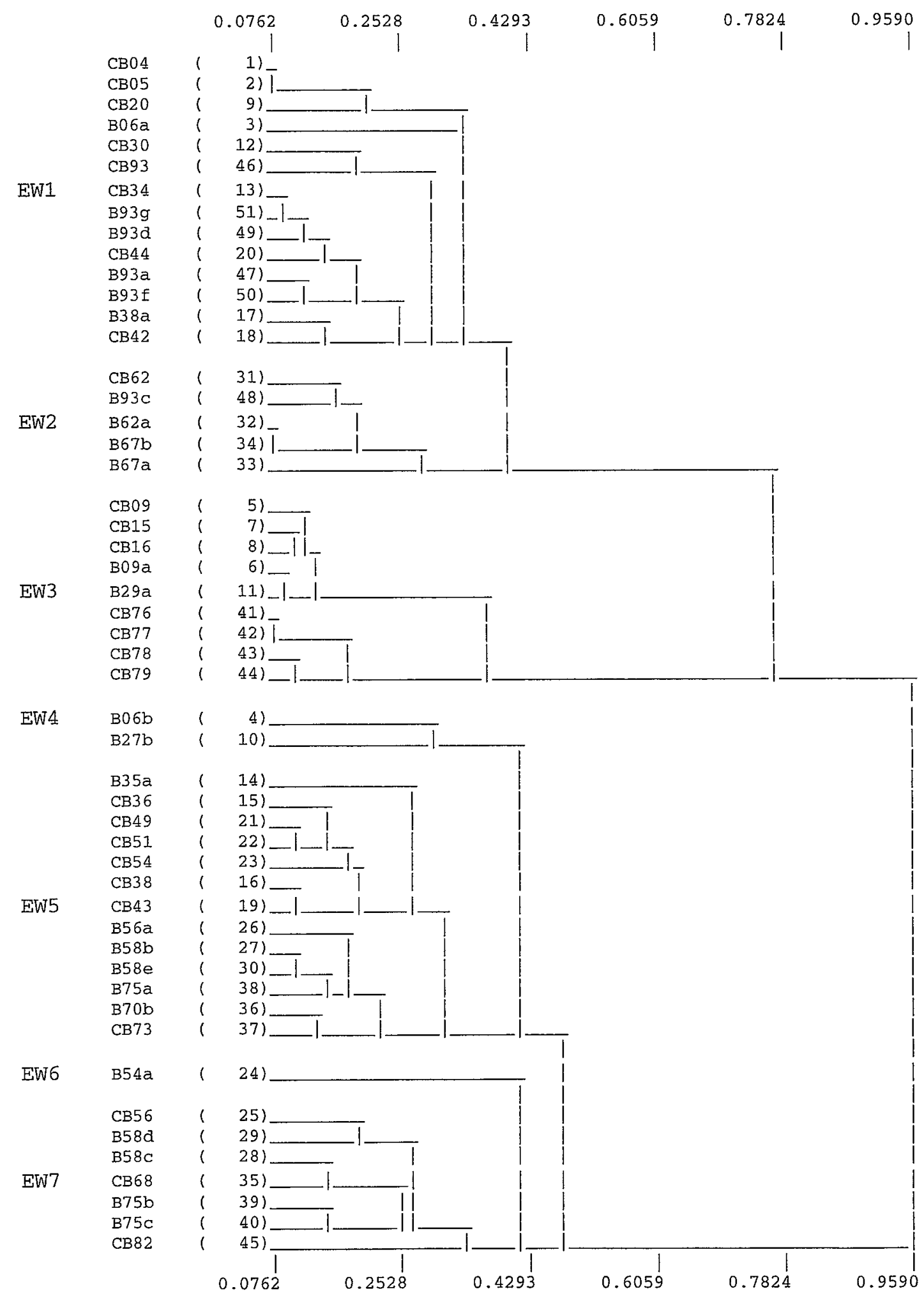

Figure 6 Classification of wetland sites in the southern Carnarvon Basin into seven groups (EW1-7) according to their environmental characteristics in winter (sites CB25 and CB62c were excluded). See Appendix 1 for site codes. 
Male ostracods that morphologically appeared to be Sarscypridopsis aculeata were collected from Minilya Pool (CB82) both times it was sampled. If this identification is correct, it is the first time males of this common, cosmopolitan species have been recorded (see De Deckker, 1981).

\section{Invertebrate communities and environmental variables}

\section{Winter}

Based on their environmental characteristics in winter, seven groups of sites were identified (Figure 6 ). These were large river and rock pools (EW1), small creeks and seeps (EW2), saline sites with a marine connection (birridas and Lake MacLeod, EW3), two very fresh claypans in the south-eastern part of the surveyed area (CB06b, CB27b: EW4), highly turbid claypans with elevated TDS values (EW5), the single crab-hole swamp sampled (CB54a: EW6) and less turbid claypans (EW7).

Seven groups of wetland sites were also identified on the basis of their use by invertebrates in winter (Figure 7). IW1 sites were river pools, rock pools in river channels and the larger flowing streams and, on average, had the highest species richness (44.5 $\pm 2.6 \mathrm{SE})$. Group IW2 sites were small flowing streams and seeps, which tended to be brackish (Table 5), and supported $28.8 \pm 4.0$ species. The bore swamp at Hamelin Station homestead (CB20) also belonged to IW2. Group IW3 contained the more speciose claypan and swamp sites (38.5 \pm 3.4 species), which were less turbid and had less coloured water. Three 'river pools' (Minilya Pool CB82, Coollilee Pool CB49 and Boolan Pool CB73) were included in this group but none received through-flow during the survey and it is likely they were ecologically more similar to claypans than rivers. Sites in IW4 were more coloured, turbid claypans with high nutrient levels and intermediate numbers of species (27.8 \pm 2.4$)$. One 'river pool' (Bulgra Pool CB70b) was in this group but physiognomically it resembled a claypan. IW5 sites were more coloured and turbid claypans with high nutrient levels and receding water levels, sometimes being close to dry. These claypans contained fewest species (18.2+1.9). Group IW6 sites were birridas and contained few species (11.0 1.5$)$ while IW7 contained the four Lake MacLeod sites, which averaged $16.0 \pm 0.9$ species. Sites in the latter two groups were saline with high ratios of calcium/ alkalinity (Table 5).

Despite some superficial similarities in site classifications based on invertebrates and environmental variables, concordance between them was poor. Using seven groupings, only 26 of the 51 sites in the two classifications fell into the same groups and the Hubert/Arabie Rand statistic was 0.3435 (1.0 indicates identical classification, 0 indicates total dissimilarity).

Ordination of the wetland sites based on invertebrate data showed the same relationships between site groupings as the classification (Figure 8). Saline sites (IW6 and 7) were strongly separated from rivers and claypans. There was minimal overlap between the three groups of claypans (IW35) but the smaller streams and springs (IW2) did not separate clearly from larger river pools (IW1). Eight variables were significantly correlated with site positions in ordination space, including the ratio of calcium/alkalinity, TDS, turbidity and colour (Table 6, Figure 8).

Table 5 Mean values ( $\pm S E$ ) of environmental variables in winter for the wetland groups identified by UPGMA cluster analysis based on winter invertebrate data. The significance values of one-way ANOVAs for each variable are shown. **** $P<0.0001$, *** $P<0.001$, NS $P>0.05$.

\begin{tabular}{|c|c|c|c|c|c|c|c|c|}
\hline \multirow[t]{2}{*}{ Variable } & \multirow[b]{2}{*}{ IW1 } & \multirow[b]{2}{*}{ IW 2} & \multirow[b]{2}{*}{ IW 3} & \multicolumn{2}{|c|}{ Wetland group } & \multirow[b]{2}{*}{ IW 6} & \multirow[b]{2}{*}{ IW 7} & \multirow[t]{2}{*}{$P$} \\
\hline & & & & IW 4 & IW 5 & & & \\
\hline $\mathrm{pH}$ & $8.6 \pm 0.2$ & $8.0 \pm 0.4$ & $8.1 \pm 0.2$ & $7.8 \pm 0.1$ & $8.3 \pm 0.3$ & $8.2 \pm 0.2$ & $8.0 \pm 0.4$ & NS \\
\hline DO (\% sat.) & $112 \pm 6$ & $134 \pm 23$ & $97 \pm 6$ & $97 \pm 4$ & $109 \pm 12$ & $115 \pm 9$ & $132 \pm 10$ & NS \\
\hline Colour (TCU) & $11 \pm 2$ & $12 \pm 4$ & $315 \pm 152$ & $879 \pm 265$ & $4432 \pm 2490$ & $8.2 \pm 3.8$ & $8.5 \pm 1.4$ & $* * * *$ \\
\hline Turbidity (NTU) & $0.7 \pm 0.2$ & $0.3 \pm 0.03$ & $2587 \pm 1195$ & $12620 \pm 5509$ & $21196 \pm 7284$ & $0.6 \pm 0.1$ & $0.14 \pm 0.05$ & $* * * *$ \\
\hline $\operatorname{TDS}(\mathrm{mg} / \mathrm{L})$ & $946 \pm 266$ & $5950 \pm 1787$ & $176 \pm 45$ & $152 \pm 47$ & $490 \pm 105$ & $94200 \pm 22767$ & $39920 \pm 2803$ & $* * * * *$ \\
\hline Ca/Alkalinity & $1.3 \pm 0.3$ & $1.8 \pm 0.3$ & $0.24 \pm 0.06$ & $0.21 \pm 0.04$ & $0.10 \pm 0.05$ & $35 \pm 3$ & $8.8 \pm 0.4$ & $* * * *$ \\
\hline $\mathrm{Ca}+\mathrm{Mg} / \mathrm{Cl}^{\mathrm{a}}$ & $1.2 \pm 0.4$ & $0.57 \pm 0.2$ & $0.87 \pm 0.3$ & $0.92 \pm 0.3$ & $0.42 \pm 0.2$ & $0.26 \pm 0.02$ & $0.25 \pm 0.01$ & NS \\
\hline $\mathrm{Ca} / \mathrm{SO}_{4}^{\mathrm{a}}$ & $3.4 \pm 1.6$ & $0.38 \pm 0.1$ & $3.0 \pm 1.3$ & $2.7 \pm 0.9$ & $2.6 \pm 1.6$ & $0.56 \pm 0.06$ & $0.45 \pm 0.05$ & NS \\
\hline Nitrogen (mg/L) & $0.67 \pm 0.17$ & $0.64 \pm 0.1$ & $1.4 \pm 0.4$ & $2.3 \pm 0.5$ & $2.2 \pm 0.5$ & $2.1 \pm 0.3$ & $0.54 \pm 0.11$ & $* * * *$ \\
\hline Phosphorus (mg/L) & $0.006 \pm 0.001$ & $0.002 \pm 0.002$ & $0.17 \pm 0.07$ & $0.41 \pm 0.16$ & $0.68 \pm 0.25$ & $0.016 \pm .002$ & $0.005 \pm 0.002$ & $* * * *$ \\
\hline Chlorophyll (mg/L) & $0.017 \pm 0.008$ & $0.009 \pm 0.003$ & $0.05 \pm 0.02$ & $0.03 \pm 0.02$ & $0.008 \pm 0.005$ & $0.008 \pm 0.003$ & $0.011 \pm 0.009$ & NS \\
\hline Latitude & $25.9 \pm 0.2$ & $24.9 \pm 0.5$ & $25.0 \pm 0.3$ & $25.1 \pm 0.3$ & $24.8 \pm 0.1$ & $26.3 \pm 0.2$ & $23.9 \pm 0.04$ & $* * *$ \\
\hline Longitude $^{b}$ & $115.0 \pm 0.1$ & $114.7 \pm 0.2$ & $114.2 \pm 0.2$ & $114.5 \pm 0.1$ & $114.2 \pm 0.2$ & $113.5 \pm 0.1$ & $113.7 \pm 0.03$ & $* * * *$ \\
\hline Flow ${ }^{c}$ & 2.3 & 3.2 & 1.1 & 1.0 & 1.0 & 1.0 & 1.0 & - \\
\hline
\end{tabular}

a ratio of ionic compositions expressed as milliequivalents

b Decimal degrees

c Flow category (see text) 


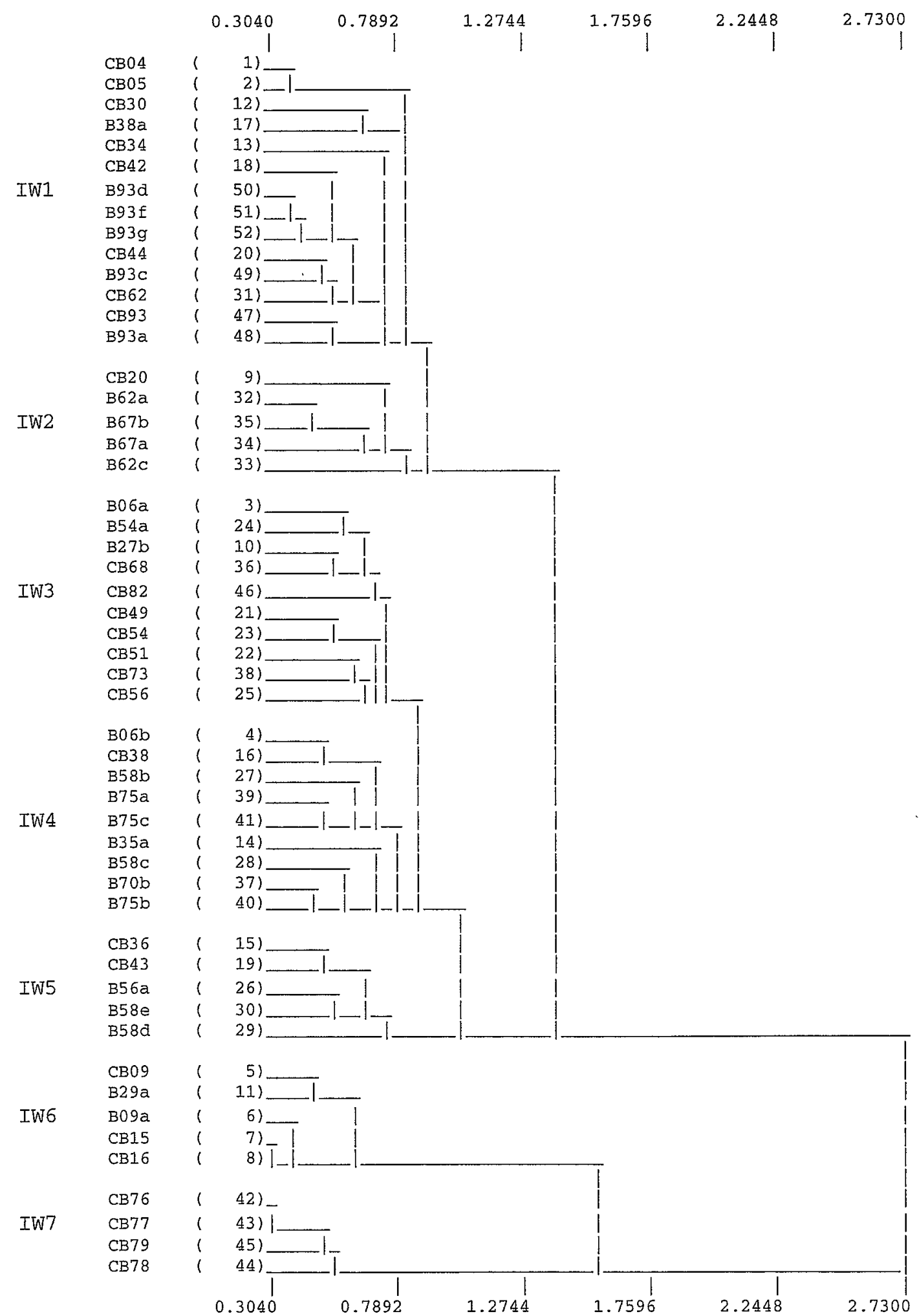

Figure 7 Classification of wetland sites in the southern Carnarvon Basin into seven groups (IW1-7) according to their invertebrate fauna in winter (site CB25 was excluded). See Appendix 1 for site codes.

Based on their pattern of occurrence in winter, sixteen groups of invertebrate species were identified. These included groups that were more or less restricted to each of site groups IW1-4 and 67. There were two groups of generalist species that occurred commonly in all but the saline sites. There was no species group restricted to IW5 sites (the depauperate drying-phase claypans) although some species showed a preference for the two turbid claypan groups (IW4 and 5).

\section{Summer}

Six groups of wetland sites were identified according to their environmental characteristics 
Table 6 Significant correlations between environmental variables and the distribution of 51 wetland sites in ordinations based on the winter and summer invertebrate faunas of the sites. $^{* *}, P<0.001 ; * *, P<0.01 ; *, P<0.05$.

\begin{tabular}{|c|c|c|c|c|}
\hline \multirow[t]{2}{*}{ Variable } & \multicolumn{2}{|c|}{$\begin{array}{c}\text { Winter } \\
\text { ordination }\end{array}$} & \multicolumn{2}{|c|}{$\begin{array}{c}\text { Summer } \\
\text { ordination }\end{array}$} \\
\hline & $r$ & $\mathbf{P}$ & $r$ & $P$ \\
\hline Calcium/alkalinity & 0.9401 & $* * *$ & 0.8347 & $* * *$ \\
\hline TDS & 0.8913 & $* * *$ & 0.7796 & $* * *$ \\
\hline Turbidity & 0.8647 & $* * *$ & 0.8724 & $* * *$ \\
\hline Colour & 0.8518 & $* * *$ & 0.6198 & $* *$ \\
\hline Flow & 0.7544 & $* * *$ & 0.7624 & $* * *$ \\
\hline Longitude & 0.6745 & $* * *$ & 0.7272 & $* * *$ \\
\hline Phosphorus & 0.6133 & $* * *$ & 0.6797 & $* * *$ \\
\hline Nitrogen & 0.5129 & $* *$ & 0.6070 & $* *$ \\
\hline Latitude & 0.4286 & $*$ & 0.5405 & ** \\
\hline
\end{tabular}

in summer. The classification showed some differences from that based on winter environmental data, perhaps because it was a smaller dataset, but rivers, marine-influenced sites and claypans still constituted the major groupings (Figure 9). Concordance of the classifications based on summer environmental and invertebrate data (Figure 10) was equivocal, with 25 of 37 sites being placed in the same groups in both classifications and a Hubert/ Arabie Rand statistic $=0.5255$.

Six groups of wetland sites were identified on the basis of their invertebrate fauna in summer (Figure 10). Group IS1 sites were mostly claypans, with the exception of two sites on the lower Murchison River (Hardabut Pool CB04 and Bullock Pool CB05), and had moderate turbidity and colour, and high species richness $(38.4 \pm 2.8)$. Group IS2 sites were claypans in the drying phase with high turbidity, high nutrient levels and moderate colour (Table 4). They had lower species richness (19.3 \pm 4.8 ). Group IS3 contained the bore swamp at Hamelin Station homestead (CB20), Birdrong Spring (CB67a) and two small flowing stream sites, which had slightly elevated TDS and averaged $30.2 \pm 3.2$ species. Group IS4 contained river pools, rock pools and larger flowing stream sites and had high numbers of species $(40.0 \pm 3.9)$. Group IS5 sites were saline birridas with very high ratios of calcium/alkalinity and few species (8.3 \pm 0.7$)$; IS6 comprised the Lake MacLeod sites, which were also saline but had more species $(15.3 \pm 2.9)$.

Fourteen groups of invertebrate species were identified, based on their pattern of occurrence at sites in summer. There were species groups restricted to all site groups except IS3 (seeps and streams), and one group of infrequently occurring species showed preference for this habitat. Several groups of generalist species occurred commonly at all but the saline sites.

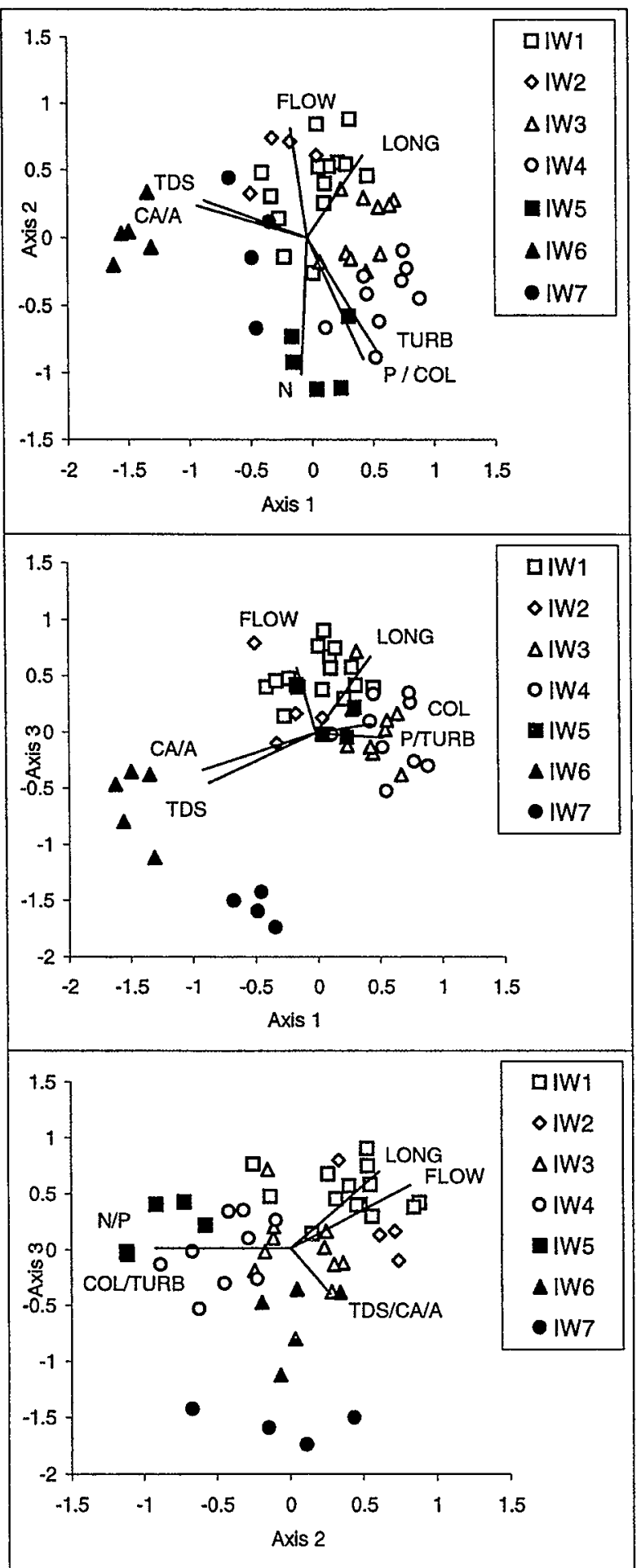

Figure 8 Ordination of wetland sites in the southern Carnarvon Basin based on their invertebrate fauna in winter, showing environmental gradients in the ordination space (three dimensions, stress $=0.17$ ).

\section{Wetland types in the southern Carnarvon Basin and important environmental parameters}

Wetland classifications derived from winter and summer invertebrate data for a common set of 34 sites showed a high degree of concordance at the five group level (Hubert/Arabie Rand 


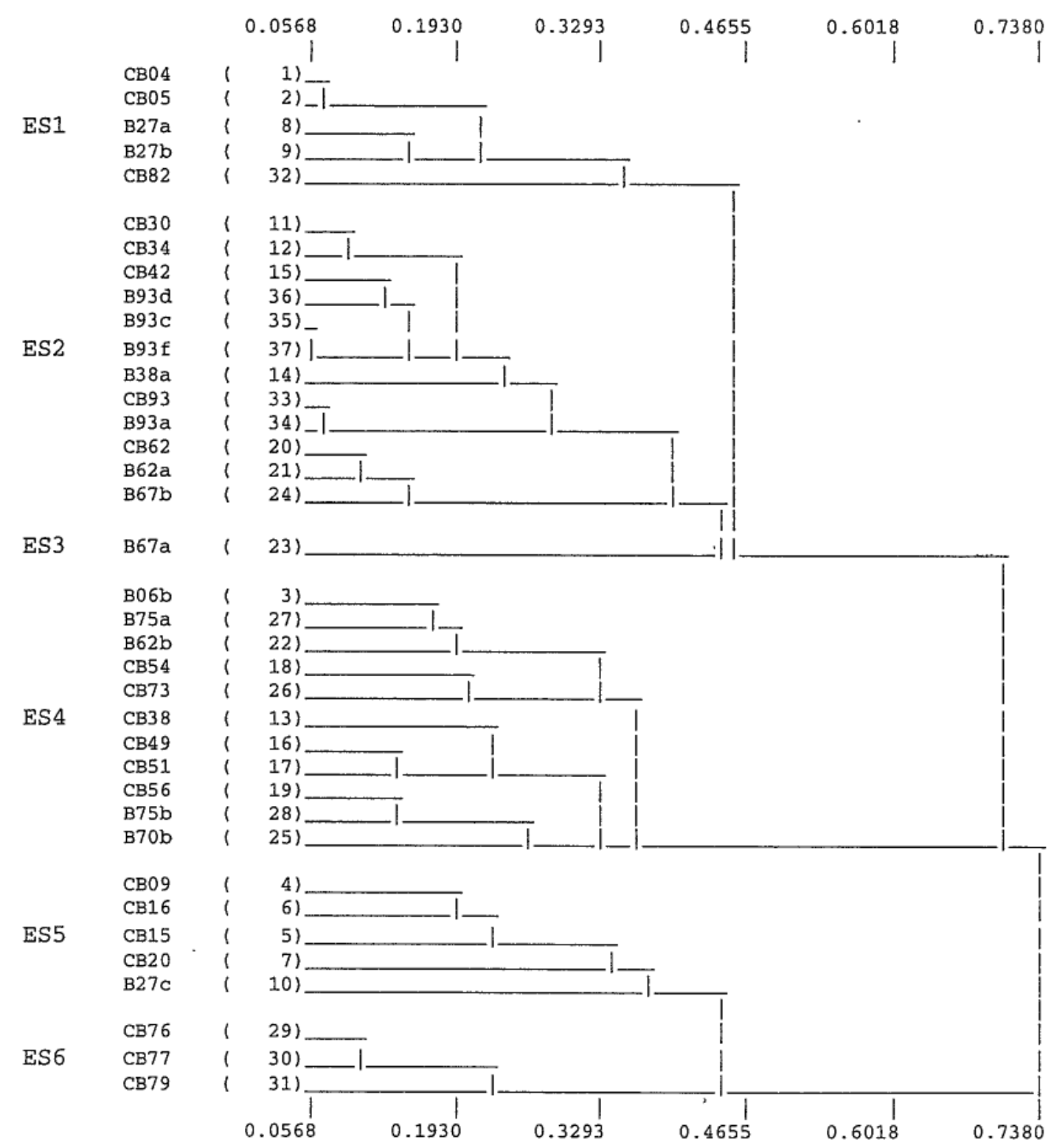

Figure 9 Classification of wetland sites in the southern Carnarvon Basin into six groups (ES1-6) based on their environmental characteristics in summer. See Appendix 1 for site codes.

statistic $=0.7963$ ), with only Hardabut and Bullock Pools (CB04 and CB05) on the lower Murchison River changing from river pool to claypan groups (see Figures 7 and 10). The Murchison River was in spate in summer and the main river channel could not be sampled. Backwaters and small pools associated with the river were sampled instead; these were likely to contain faunas with stronger claypan elements than the river channel and may have caused the changes in classification.

All classifications based on invertebrate data showed the existence of five major wetland groupings: (1) river pools, rock pools and larger flowing streams, (2) seeps, springs and small flowing streams, (3) claypans, (4) birridas, and (5) Lake MacLeod. There were slight differences between seasons in terms of environmental variables that were best related to invertebrate community composition but ratio of calcium/ alkalinity, TDS, turbidity, colour, flow, longitude, phosphorus and nitrogen were significant both seasons (Table 6.). Several of these variables were inter-correlated (Table 7).

\section{DISCUSSION}

Climatic variation has considerable implications for any attempt to document the fauna of a region such as the southern Carnarvon Basin. Apart from obvious sampling difficulties if wetlands remain dry in low rainfall years, the fauna of many sites differs according to whether they are full or partially flooded. A Western Australian example of almost complete turnover of invertebrate fauna was provided by Lake Gregory, southern Kimberley, between 1989 and 1991, as a result of the lake flooding and salinity being dramatically reduced (Halse et al., 1998b). The total aquatic invertebrate 


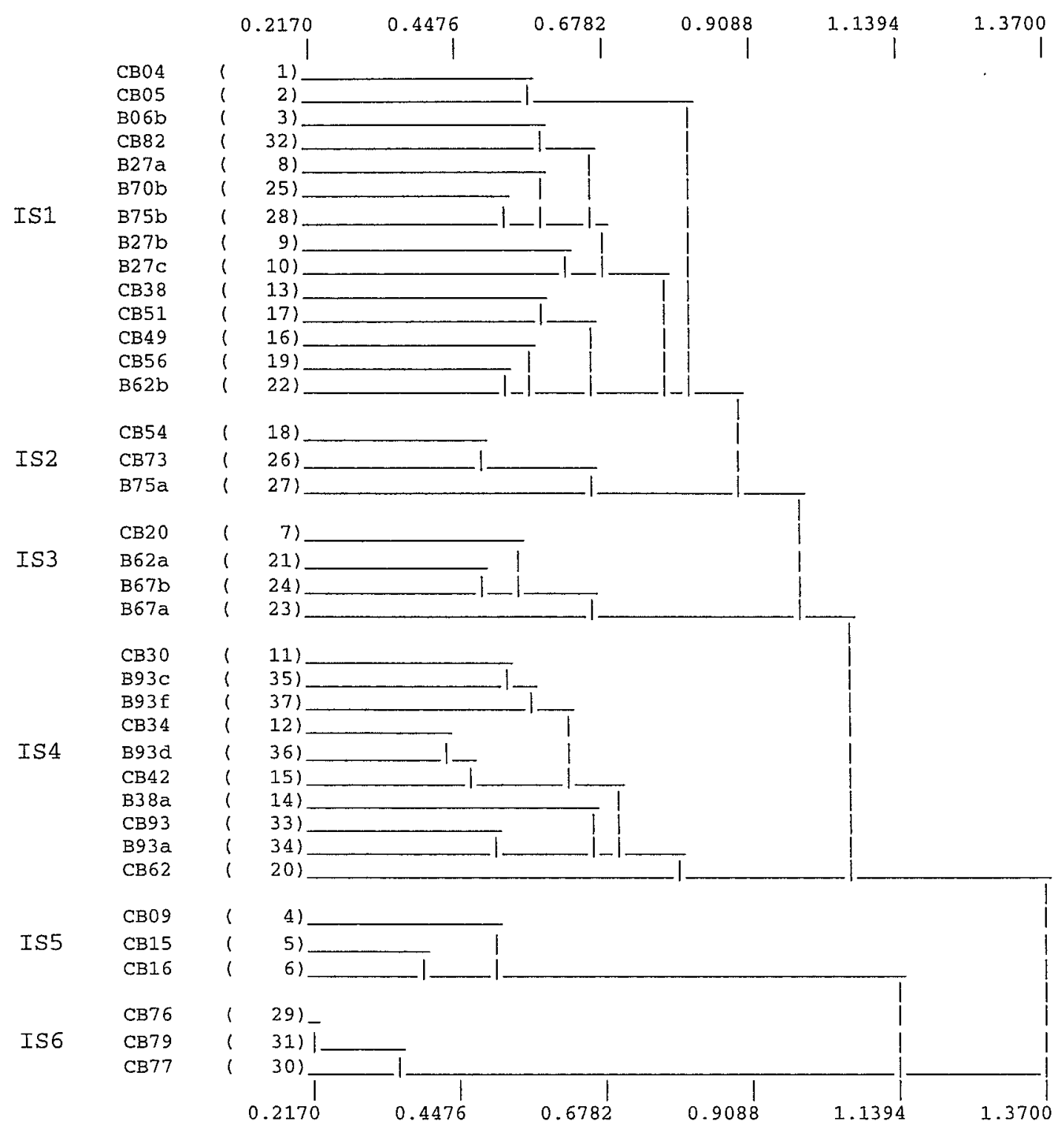

Figure 10 Classification of wetland sites in the southern Carnarvon Basin into six groups (IS1-6) according to their invertebrate fauna in summer. See Appendix 1 for site codes.

Table 7 Highly significant correlations $(P<0.001)$ between environmental variables in winter and summer in southern Carnarvon Basin wetlands.

\begin{tabular}{|c|c|c|}
\hline \multirow[t]{2}{*}{ Variables } & \multicolumn{2}{|c|}{$r$} \\
\hline & Winter & Summer \\
\hline TDS and calcium/alkalinity & 0.795 & 0.611 \\
\hline Colour and phosphorus & 0.666 & 0.817 \\
\hline Colour and turbidity & 0.561 & 0.758 \\
\hline Flow and longitude & 0.534 & - \\
\hline Phosphorus and turbidity & 0.477 & 0.624 \\
\hline TDS and longitude & -0.462 & -0.497 \\
\hline Nitrogen and colour & 0.452 & 0.640 \\
\hline Nitrogen and turbidity & - & 0.575 \\
\hline
\end{tabular}

fauna of an area such as the southern Carnarvon Basin is unlikely to be documented in one year (especially a dry year), nor can the conservation value of individual wetlands be assessed fully. Depending on rainfall patterns, the full value of a wetland may be expressed at intervals of many years or even decades (see Halse et al., 1998a).

\section{Waterbirds}

Waterbird data collected during this survey reflected what was already known about broad distributional patterns in the southern Carnarvon Basin (Johnstone et al., 2000). Data from individual sites highlighted the importance of pools in larger rivers, rather than freshwater claypans, as waterbird habitat. Timms (1997) found turbid freshwater claypans in northern New South Wales were also little used by waterbirds. 
Two groups in the wetland classification contained most sites with high waterbird conservation value (B1, river pools and vegetated swamps; B2, Lake MacLeod), although B3 contained Lake Julia (CB62b) and Minilya Pool (CB82), which were among the richer sites in the Basin for waterbirds, and $\mathrm{B} 7$ contained the pan north of Big Lagoon (CB29a), which clearly had potential to support large numbers of migratory shorebirds. The survey reinforced the pre-eminent status of Lake MacLeod as waterbird habitat in the southern Carnarvon Basin (Smith and Johnstone, 1985; Lane et al., 1996) but also showed that some species do not utilise the lake and rely on other habitats, especially river pools (Figure 5). Twenty-one sites were excluded from analyses because either no waterbird or only one species was recorded. There are many possible reasons for waterbirds not being recorded at a site and depauperate sites should not be treated as a natural grouping.

Although we analysed the waterbird data, results should be used cautiously. Sampling effort was low and variable, with a maximum of three surveys per site. Extra surveys would have increased the waterbird list at most sites: for example, two additional surveys at three sites produced an average of 2.7 extra species (Table 8 ). A further complication is that waterbird populations may have been unusually low, and thus waterbird use of sites unrepresentative, during the summer 1995 sampling period because of widespread, aboveaverage inland rain (Figure 2). Rainfall in the Goldfields between January and March 1995 was the highest on record (Bureau of Meteorology, 1995). Thirteen sites, at which waterbirds were surveyed during summer both in the 1994 reconnaissance trip and in 1995, had almost three times more species in 1994 than $1995(3.8 \pm 1.0$ vs $1.3 \pm 0.4$ ), when most of the summer surveying was done. This suggests that the phenomenon of

Table 8 Numbers of waterbird species recorded at three sites in three sampling periods during the survey (summer 1994 to summer 1995) and in two subsequent surveys (winter 1995 and summer 1996). Numbers of species first seen in winter 1995 or summer 1996 are also shown. See Appendix 1 for explanation of site codes. ns, not surveyed.

\begin{tabular}{llll}
\hline & CB05 & CB42 & CB82 \\
\hline Summer 1994 & 6 & 2 & $\mathrm{~ns}$ \\
Winter 1994 & 7 & 12 & 10 \\
Summer 1995 & 1 & 0 & 2 \\
Winter 1995 & 5 & 6 & 6 \\
Summer 1996 & 11 & 10 & 1 \\
Extra species winter 1995 & 2 & 0 & 1 \\
Extra species summer 1996 & 4 & 1 & 0 \\
Total number of species & 15 & 14 & 11 \\
\hline
\end{tabular}

waterbirds moving inland from coastal regions after rain (Bekle, 1983; Halse et al., 1992) applies in the arid as well as the temperate zone.

\section{Aquatic invertebrates}

\section{Wetland classifications and environmental variables}

As for waterbirds, some aspects of the aquatic invertebrate analysis should be used cautiously. The invertebrate surveys were not conducted during particularly wet years, although Carnarvon and eastern parts of the Basin received aboveaverage rainfall in summer 1995 (Table 1, Figure 2), and some of the wetlands chosen during reconnaissance were dry during all three sampling periods. These included the drier type of 'crabhole' swamps, representatives of which were identified on Carbla and Minilya Stations. Site CB25 on Yaringa Station, the only saline claypan identified in the study area that did not have existing marine connections, was sampled but, because it was in the final stages of drying, contained a depauperate, unrepresentative fauna and was excluded from analyses.

Wetland classifications derived from invertebrate data gave consistent patterns across seasons with five major types of wetland site being recognized (1) river pools, rock pools and larger flowing streams, (2) seeps, springs and small flowing streams, (3) claypans, (4) birridas, and (5) Lake MacLeod. The claypan group could be further divided on the basis of turbidity and stage in the drying cycle (Figures 7 and 8). Less turbid claypans and those where water levels had not receded noticeably had higher species richness, although some species were more or less restricted to highly turbid and drying-phase claypans. Saline pans without current marine influence, such as CB25, may comprise a sixth, uncommon type of wetland.

Previous studies of community composition in wetlands of Western Australia have examined much smaller geographic areas and a restricted range of wetland types. Growns et al. (1992) and Davis et al. (1993) classified 40 shallow, permanent or seasonal lakes on the Swan Coastal Plain according to their invertebrate communities and found two small outlying groups, one of which was related to high salinity and the other to low $\mathrm{pH}$. Groupings among the remaining wetlands appeared to be related to colour and nutrients. In a similar analysis of 23 shallow, permanent lakes on the south-western coast, Edward et al. (1994) found groupings based on invertebrate communities appeared to be related to salinity (although all salinities were $<3000 \mathrm{mg} \mathrm{L}^{-1}$ ) and nutrients. In a study of the macroinvertebrate communities of rivers across north-western Australia, based on family-level identifications, Kay et al. (1999) found variables measuring geographic position, salinity 
and river discharge were more important than turbidity, alkalinity and nutrients.

In this survey, wetland groups based on invertebrate communities were best correlated with ratio of calcium/alkalinity (not measured in other studies), salinity, turbidity, colour, flow (which separated rivers and springs from lentic wetlands), geographic position, phosphorus and nitrogen. Storey et al. (1993) suggested that environmental variables best related to wetland groupings vary according to the range of wetland types being studied, scale of the study and landscape setting. For example, environmental variables such as ratio of calcium/alkalinity will show far more variation if birridas, rivers and freshwater claypans are sampled than if only one wetland type is studied. In surveys of small areas, geographical coordinates are unlikely to be important. Similarly, turbidity will probably be more variable in lentic waterbodies than rivers, and show greater variation in northwestern Australia, where soils often contain a high proportion of clay or loam, than on the Swan Coastal Plain, where they are sandy.

Inter-correlation among environmental variables in this survey creates doubt about the validity of some correlations between wetland groupings and environmental variables. The observed correlation between longitude and wetland groupings may have been at least partially the result of strong correlations with TDS, flow regime or distance from the coast (which was not measured), rather than reflecting large-scale zoogeographic pattern. Strong inter-correlations between nutrients, turbidity and colour may obscure the relative influence of these variables on community composition.

\section{Biogeography}

Analysis of biogeographical patterns in the southern Carnarvon Basin data is made difficult by the fact that distributions of most aquatic invertebrates are poorly known. About 50 species previously thought to be restricted to the eastern half of Australia were recorded in this survey and species that currently appear endemic to the Basin may be recorded elsewhere when surveys are conducted in other little studied regions of Australia. Inability to identify some faunal groups to species level further obscures biogeographical patterns, as well as preventing assessment of the conservation status of the unidentified animals. Despite being a major component of the fauna of Australian wetlands (e.g. Geddes et al., 1981; Davis et al., 1993), about $40 \%$ of ostracods collected were either undescribed or could not be confidently identified to species level. None of the ceratopogonid dipteran larvae could be identified to species.

Most of the undescribed species collected in the southern Carnarvon Basin are probably widespread
(Table 4). Lack of survey in Western Australia means that many widespread species have been recorded rarely. For example, for 50 years the only known Australian locality of the harpacticoid Cletocamptus confluens was Shark Bay (Lang 1948), until it was found throughout Western Australia in the 1990s (Halse et al., 1996; this study; Halse, unpubl. data). However, some species belonging to groups for which there has been comparatively high collecting effort should probably be treated as endemic to the Basin until there is evidence to the contrary. These include the calanoid copepod Calamoecia halsei (Bayly, 1998), several ostracods and the anostracan Branchinella sp. nov. (aff. lyrifera).

Gibson et al. (2000) found that, while most of the wetland flora in the southern Carnarvon Basin was typical of arid areas, significant numbers of southwestern and tropical species occurred at the northern and southern limits, respectively, of their ranges. The same is true for aquatic invertebrates and the southern Carnarvon Basin appears to represent a zone where Bassian and Torresian biotic elements meet (see Serventy and Whittell, 1967). Examples of Torresian species that have extended their range southwards are the copepod Eudiaptomus lumholtzi (see Timms and Morton, 1988) and beetles Berosus dallasae and Hydroglyphus leai (see Watts, 1978, 1987). Examples of Bassian species extending north are the copepod Calamoecia tasmanica subattenuata (see Maly et al., 1997) and ostracods Mytilocypris mytiloides and Australocypris insularis (see De Deckker, 1978). Nevertheless, most aquatic invertebrates in the Basin either have Eyrean affinities or occur throughout Australia. Groups such as anostracans and notostracans are typical of the former (Geddes, 1981; Williams, 1968); many corixid hemipterans are examples of the latter (Wroblewski, 1972; Knowles, 1974).

Until now, only the chironomid Archaeochlus, which occurs in small temporary streams on granite outcrops in south-western Australia and is also known from the Drakensberg Escarpment and Namibia in southern Africa, was recognized as a Gondwanan relic in arid parts of Western Australia (Edward, 1986; Cranston et al., 1987). The occurrence of aquatic invertebrates, hitherto known only from South America, in the southern Carnarvon Basin raises the possibility that Gondwanan relics may occur quite commonly in arid areas. It seems unlikely that the copepod Robertsonia mourei, which occurs in Lake MacLeod, could have been transported by migratory shorebirds (Procter et al., 1967) because there is no established flyway between South America and Western Australia. The rotifer Hexarthra brandorffi seems even more unlikely to have been translocated and almost certainly represents a relictual species. Similarly, the undescribed Daphnia sp. nov. (aff. barbata) and $D$. sp. nov. (aff. gibba) have strong 
African affinities and may be Gondwanan (C. Wilson, pers. comm.). Past studies of Gondwanan relics in Western Australia have focussed on the wetter south-west (Edward, 1989; Cranston and Edward, 1992; Horwitz, 1997) and the significance of arid areas as habitat may have been underestimated, particularly for species with a resistant stage in their life history.

\section{Wetland community patterns}

Waterbirds and aquatic invertebrates in southwestern Australia appear to respond to the same environmental variables, such as salinity and nutrient levels (see Davis et. al., 1993; Halse et al., 1993; Storey et al., 1993), yet wetlands supporting the largest numbers of waterbird species frequently differ from those with most invertebrates. For example, in a recent survey on the Swan Coastal Plain none of the five wetlands with highest invertebrate richness (Davis et. al., 1993) were among the 20 wetlands with highest waterbird richness or most breeding waterbird species (Storey et al., 1993).

The same pattern applied in the southern Carnarvon Basin. Although there was some superficial agreement between classifications of sites based on waterbirds and aquatic invertebrates, site-by-site comparisons suggested that the processes underlying formation of waterbird and invertebrate assemblages were different. Information about community composition of waterbirds at a wetland could not be inferred reliably from data on invertebrates or vice versa (cf. Figures 3 and 7). Plant communities provided even less information about the biota: the same plant community occurred at marine sites $\mathrm{CB} 09$ and CB77, brackish river site $\mathrm{CB} 38 \mathrm{a}$ and freshwater coastal pan CB36 (Figure 2 in Gibson et al., 2000), despite these sites supporting three waterbird and four invertebrate communities (Figures 3 and 7). The Carnarvon Basin results mirror those of Yen (1987), who found terrestrial beetles, mammals and vegetation each provided only limited information about the composition of the other two biotic elements at sites in Victoria.

Lack of concordance between classifications based on different taxonomic elements means that inventory of each element is required to identify distribution patterns and important habitats before strategies can be prepared for the conservation and protection of that element. Wetlands with low conservation value for plants may be important for invertebrates or waterbirds.

\section{Rare species and their conservation}

A third of aquatic invertebrate taxa were collected only once during this survey (Table 3 ). The phenomenon was even more pronounced in the flora, with $55 \%$ of species occurring at only one wetland (Gibson et al., 2000). The most obvious implication for both invertebrates and plants is that the number of species recorded in the Basin will grow as survey effort is increased.

Infrequent occurrence may be the result of aquatic invertebrates occurring in a narrow range of wetland types or conditions, being present for a short time in the flooding cycle, or having poor colonizing ability and locally restricted distributions. Maly et al. (1997) argued that poor dispersal, rather than narrow ecological tolerances, shaped the distribution of most calanoid copepods in Australia. However, many of the species with a single occurrence in the Basin were insects (see Appendix 4) with strong powers of flight. Differences between communities of drying-phase (IW5 in winter and IS2 in summer) and other claypans suggested that temporal succession may have contributed to sporadic collection of some species but it seems unlikely to have been the factor underlying all rare occurrences. Gibson et al. (2000) suggested the southern Carnarvon Basin naturally contains many rare plant species and the same seems true for aquatic invertebrate species, although the reasons for rarity are not understood.

Rarity or infrequent occurrence of aquatic invertebrates and other species poses problems for their conservation, particularly when it is unclear whether they are restricted to very few wetlands or occur very infrequently at many sites. Given the high proportion of 'rare' species with poorly understood and unpredictable distributions, it is unlikely that all species can be conserved in a regional nature reserve system. The realistic objective for the reserve system should be protection of examples of all wetland types in the southern Carnarvon Basin and their typical invertebrate communities. Other mechanisms, designed to ensure careful management of wetlands on different land tenures, will be a necessary adjunct to nature reserves for conservation of some rarer, or infrequently occurring, species.

\section{ACKNOWLEDGEMENTS}

Funding was provided by the Commonwealth through the National Reserves System Co-operative Program of the Australian Nature Conservation Agency (now Environment Australia), together with funds provided by the Western Australian Department of Conservation and Land Management. We thank W.R. Kay for help with statistical analyses, R. Schulz for chemical analyses, A. Clarke for sorting invertebrate samples and the following for assistance with identifications: I.A.E. Bayly (some calanoids), D. Belk (some anostracans), R. Hamond (harpacticoids), S.A. Harrington (culicids), J.M. McRae (polychaetes), J.K. Moulton (simuliids), G.L. Pesce (some cyclopoids), S. Slack- 
Smith (molluscs), P.J. Suter (ephemeropterans), R.M. St Clair (trichopterans), C.H.S. Watts (coleopterans) and C. Wilson (Daphnia). A. Clarke, W.R. Kay and M.J. Smith assisted with fieldwork, N. Hall did much of the databasing and M.N. Lyons produced Figure 1.

\section{REFERENCES}

Anonymous (1984). Streamflow records of Western Australia, vol. 3, basins 618-809. Public Works Department, Perth.

Anonymous (1995). Australia's world heritage. Department of Environment, Sports and Territories, Canberra.

APHA (1989). Standard methods for the examination of water and wastewater. American Public Health Association, Washington.

Austin, M.P. and Belbin, L. (1982). A new approach to the species classification problems in floristic analysis. Australian Journal of Ecology 7: 75-89.

Bayly, I.A.E. (1998). New. species of Calamoecia and Boeckella (freshwater Copepoda: Calanoida) from Western Australia and Queensland. Journal of the Royal Society of Western Australia 81: 177-182.

Bekle, H. (1983). Effects of unseasonable rains in January 1982 on waterfowl in south-western Australia. II. Records of late breeding from inland localities. Western Australian Naturalist 15: 126-130.

Belbin, L. (1991). Semi-Strong Hybrid Scaling: a new ordination algorithm. Journal of Vegetation Science 2: 491-496.

Belbin, L. (1993). PATN: pattern analysis package. CSIRO, Canberra.

Blakers, M., Davies, S.J.J.F. and Reilly, P.N. (1984). The atlas of Australian birds. Melbourne University Press, Melbourne.

Burbidge, A.H., McKenzie, N.L. and Harvey, M.S. (2000). A biogeographic survey of the southern Camarvon Basin, Western Australia: background and methods. Records of the Western Australian Museum Supplement No. 61: 1-12.

Bureau of Meteorology (1995). Monthly rainfall review, Australia. Bureau of Meteorology, National Climate Centre, Melbourne.

Cranston, P.S. (1994) The immature stages of the Australian Chironomidae. Taxonomy Notes 1. Co-operative Research Centre for Freshwater Ecology, Albury.

Cranston, P.S., Edward, D.H.D. and Colless, D. (1987). Archaeochlus Brundin - a midge out of time (Diptera: Chironomidae). Systematic Entomology 12: 313-334.

Cranston, P.S. and Edward, D.H.D. (1992). A systematic reappraisal of the Australian Aphroteniinae (Diptera: Chironomidae) with dating from vicariance biogeography. Systematic Entomology 17: 41-51.

Davis, J.A., Rosich, R.S., Bradley, J.S., Growns, J.E., Schmidt, L.G. and Cheal, F. (1993). Wetlands of the Swan Coastal Plain, vol. 6. Wetland classification on the basis of water quality and invertebrate community data. Water Authority of Western Australia, Perth.
De Deckker, P. (1978). Comparative morphology and review of mytilocyprinid ostracods (family Cyprididae). Australian Journal of Zoology Supplement 58: $1-62$.

De Deckker, P. (1981). Ostracoda from Australian inland waters - notes on taxonomy and ecology. Transactions of the Royal Society of Victoria 93: 43-85.

De Laurentiis, P., Pesce, G.L. and Halse, S.A. (1997). Discovery of the first representative of the genus Neocyclops Gurney in Australia, and description of Neocyclops (Neocyclops) petkovsii n. sp. (Copepoda, Halicyclopinae). Bulletin Zoölogisch Museum Universiteit van Amsterdam 16: 15-19.

De Smet, W.H. (1996). Rotifera, Vol. 4. The Proalidae (Monogononta). Guides to the identification of the microinvertebrates of the continental waters of the world. Vol. 9. SPB Academic Publishing, The Hague.

Edward, D.H.D. (1986). Chironomidae (Diptera) of Australia. In De Deckker, P. and Williams, W.D. (eds). Limnology in Australia. CSIRO, Melbourne.

Edward, D.H.D. (1989). Gondwanaland elements in the Chironomidae (Diptera) of south-western Australia. Acta Biologica Debrecen Oecologica Hungarica 2: 181187.

Edward, D.H., Gazey, P. and Davies, P.M. (1994). Invertebrate community structure related to physicochemical parameters of permanent lakes of the south coast of Western Australia. Journal of the Royal Society of Western Australia 77: 51-63.

Frey, D.G. (1991). The species of Pleuroxus and of three related genera (Anomopoda, Chydoridae) in southern Australia and New Zealand. Records of the Australian Museum 43: 291-372.

Geddes, M. C. (1981). Revision of Australian species of Branchinella (Crustacea: Anostraca). Australian Journal of Marine and Freshwater Research 32: 253-295.

Geddes, M.C., De Deckker, P., Williams, W.D., Morton, D.W. and Topping, M. (1981). On the chemistry and biota of some saline lakes in Western Australia. Hydrobiologia 82: 201-222.

Gentilli, J. (1972). Australian climate patterns. Nelson, Melbourne.

Gibson, N., Keighery, G.J. and Lyons, M.N. (2000). Vascular flora of the wetlands and rivers of the southern Carnarvon basin, Western Australia. Records of the Western Australian Museum Supplement No. 61: 175-199.

Growns, J.E., Davis, J.A., Cheal, F., Schmidt, L.G., Rosich, R.S. and Bradley, S.J. (1992). Multivariate pattern analysis of wetland invertebrate communities and environmental variables in Western Australia. Australian Journal of Ecology 17: 275-288.

Halse, S.A., Vervest, R.M., Munro, D.R., Pearson, G.B. and Yung, F.H. (1992). Annual waterfowl counts in south-west Western Australia - 1989/90. Technical Report 29. Department of Conservation and Land Management, Perth.

Halse, S.A., Williams, M.R., Jaensch, R.P. and Lane, J.A.K. (1993). Wetland characteristics and waterbird use of wetlands in south-western Australia. Wildlife Research 20, 103-126. 
Halse, S.A., Shiel, R.J. and Pearson, G.B. 1996. Waterbirds and aquatic invertebrates of swamps on the VictoriaBonaparte mudflat, northern Western Australia. Journal of the Royal Society of Western Australia 79: 217224.

Halse, S.A., Pearson, G.B. and Kay, W.R. (1998a) Arid zone networks in time and space: waterbird use of Lake Gregory in north-western Australia. International Journal of Ecology and Environmental Sciences 24: 207222.

Halse, S.A., Shiel, R.J. and Williams, W.D. (1998b). Aquatic invertebrates of Lake Gregory, north-western Australia, in relation to salinity and ionic composition. Hydrobiologia 381: 15-29.

Horwitz, P. (1997). Comparative endemism and richness of the aquatic invertebrate fauna in peatlands and shrublands of far south-west Australia. Memoirs of the Museum of Victoria 56: 313-321.

Hubert, L. and Arabie, P. (1985). Comparing partitions. Journal of Classification 2: 193-218.

Jaensch, R.P. and Vervest, R.M. (1990). Waterbirds in remote wetlands in Western Australia, 1986-8, Part 2: Lake MacLeod, Shark Bay, Camballin Floodplain and Parry Floodplain. Report 69. Royal Australasian Ornithologists Union, Melbourne.

Johnstone, R.E., Burbidge, A.H. and Stone, P. (2000). Birds of the southern Carnarvon Basin, Western Australia. Records of the Western Australian Museum Supplement No. 61: 371-448.

Kay, W.R., Smith, M.J., Pinder, A.M., McRae, J.M., Davis, J.A. and Halse, S.A. (1999). Patterns of distribution of macroinvertebrate families in rivers of north-western Australia. Freshwater Biology 41: 299-316

Koste, W. (1978). Rotatoria - Die rädertiere Mitteleuropas (Uberordnung Monogononta). 2 Vols. Borntraeger, Stuttgart.

Koste, W. and Shiel, R.J. (1983). Morphology, systematics and ecology of new monogonont Rotifera from the Alligator Rivers region, Northern Territory. Transactions of the Royal Society of South Australia 107: 109-121.

Knowles, J.N. (1974). A revision of Australian species of Agraptocorixa Kirkaldy and Diaprepocoris (Heteroptera: Corixidae). Australian Journal of Marine and Freshwater Research 25: 173-191.

Lane, J., Jaensch, R. and Lynch, R. (1996). Western Australia. In Blackley, R., Usback, S. and Langford, K. (eds) A directory of important wetlands in Australia. Australian Nature Conservation Agency, Canberra.

Lang, K. (1948). Monographie der Harpacticoiden. Hakan Ohlsson, Lund.

Lansbury, I. (1969). The genus Anisops in Australia (Hemiptera-Heteroptera, Notonectidae). Journal of Natural History 3: 433-458

Maly, E.J., Halse, S.A. and Maly, M.P. (1997). Distribution and incidence patterns of Boeckella, Calamoecia, and Hemiboeckella (Copepoda: Calanoida) in Western Australia. Marine and Freshwater Research 48: 615-621.

McKenzie, K.G. (1971). Palaeozoogeography of freshwater Ostracoda. Bulletin du Centre de Recherches de Pau Societe Nationale des Petrole S D Aquitaine 5: Supplement 207-237.

McKenzie, N.L., Halse, S.A. and Gibson, N. (2000). A nature conservation reserve system for the southern Carnarvon Basin. Records of the Western Australian Museum Supplement No. 61: 547-567.

Menke, A.S. (1960). A review of the genus Lethocerus (Hemiptera: Belostomatidae) in the eastern hemisphere with description of a new species from Australia. Australian Journal of Zoology 8: 285288.

Nogueira, M.H. (1961). Robertsonia mourei n. sp., encontrada na Lagoda da Conceicao - Santa Catarina (Copepoda, Harpacticoidea). Buletim da Universidade do Parana Curitiba 10: 1-7.

Procter, V.W., Malone, C.R. and De Vlaming, V.L. (1967). Dispersal of aquatic organisms: viability of disseminules recovered from the intestinal tract of captive Killdeer. Ecology 48: 672-676.

SAS Institute. (1989). SAS/STAT user's guide, version 6, 4th edn. SAS Institute Inc., Cary.

Serventy, D.L. and Whittell, H.M. (1967). Birds of Western Australia. Lamb Publications, Perth.

Shiel, R.J. and Koste, W. (1979). Rotifera recorded from Australia. Transactions of the Royal Society of South Australia 103: 57-68.

Smith, L.A. and Johnstone, R.E. (1985). The birds of Lake MacLeod, upper west coast, Western Australia. Western Australia Naturalist 16: 83-87.

Smirnov, N.N. and Timms, B.V. (1983). Revision of the Australian Cladocera (Crustacea). Records of the Australian Museum Supplement 1: 1-132.

Sneath, P.H.A., and Sokal, R.R. (1973). Numerical taxonomy: the principles and practice of numerical classification. Freeman, San Francisco.

Storey, A.W., Vervest, R.M., Pearson, G.B. and Halse, S.A. (1993). Wetlands of the Swan Coastal Plain, vol. 7: Waterbird usage of wetlands on the Swan Coastal Plain. Water Authority of Western Australia, Perth.

Timms, B.V. (1988). The biogeography of Cladocera (Crustacea) in tropical Australia. Internationale Reoue der Gesampten Hydrobiologie 73: 337-356.

Timms, B.V. (1997). A comparison between saline and freshwater wetlands on Bloodwood Station, the Paroo, Australia, with special reference to their use by waterbirds. International Journal of Salt Lake Research 5: 287-313.

Timms, B.V. and Morton, D.W. (1988). Crustacean zooplankton assemblages in freshwater of tropical Australia. Hydrobiologia 164: 161-169.

Watts, C.H.S. (1978). A revision of the Australian Dytiscidae (Coleoptera). Australian Journal of Zoology Supplement 57: 1-166.

Watts, C.H.S. (1987). Revision of the Australian Berosus Leach (Coleoptera: Hydrophilidae). Records of the South Australian Museum 21: 1-28.

Williams, W.D. (1968). The distribution of Triops and Lepidurus (Branchiopoda) in Australia. Crustaceana 14: 119-126. 
Wroblewski, A. (1970). Notes on Australian Micronectinae (Heteroptera, Corixidae). Polskie Pismo Entomologiczne 40: 681-703.

Wyrwoll, K.-H., Stoneman, T., Elliott, G. and Sandercock, P. (2000). The geo-ecological setting of the Carnarvon Basin, Western Australia. Records of the Western Australian Museum Supplement No. 61: 29-75.
Yen, A.L. 1987. A preliminary assessment of the correlation between plant, vertebrate and coleoptera communities in the Victorian Mallee. In Majer, J.D. (ed.) The role of invertebrates in conservation and biological survey. Department of Conservation and Land Management, Perth.

Manuscript received 29 June 1998; accepted 4 August 1998. 


\section{Appendix 1}

Wetland sites sampled in the southern Carnarvon Basin, 1994-95. * sampled August 1994, $\ddagger$ October 1994, \# July 1995 (winter), + March 1995 (summer).

\begin{tabular}{|c|c|c|c|c|c|}
\hline Site no & Name & Latitude & Longitude & Tenure & Type \\
\hline $\mathrm{CBO} 4^{*}+$ & Hardabut Pool & $27^{\circ} 53^{\prime} 11^{\prime \prime S}$ & $114^{\circ} 34^{\prime} 04^{\prime \prime} \mathrm{E}$ & Mt View & Billabong \\
\hline CBO5*t & Bullock Pool & $27^{\circ} 49^{\prime} 04^{\prime \prime S}$ & $114^{\circ} 46^{\prime} 31^{\prime \prime E}$ & Riverside & River pool \\
\hline CВ06а* $\mathbf{t}$ & Un-named swamp & $27^{\circ} 31^{\prime} 26^{\prime \prime S}$ & $115^{\circ} 04^{\prime} 20^{\prime \prime} \mathrm{E}$ & Coolcalalaya & Ephemeral swamp \\
\hline $\mathrm{CBO}^{*} \mathrm{~b}^{*} \mathrm{t}$ & Un-named claypan & $27^{\circ} 31^{\prime 2} 29^{\prime \prime S}$ & $115^{\circ} 05^{\prime} 14^{\prime \prime} \mathrm{E}$ & Coolcalalaya & Ephemeral pan \\
\hline CB09*t & Un-named birrida & $26^{\circ} 45^{\prime} 13^{\prime \prime} \mathrm{S}$ & $113^{\circ} 42^{\prime} 34^{\prime \prime E}$ & Tamala & Birrida \\
\hline CB09a* & Un-named birrida & $26^{\circ} 44^{\prime} 31^{\prime \prime} \mathrm{S}$ & $113^{\circ} 42^{\prime} 37^{\prime \prime} \mathrm{E}$ & Tamala & Birrida \\
\hline $\mathrm{CB} 15^{*} \mathbf{t}$ & Un-named birrida & $26^{\circ} 23^{\prime} 05^{\prime \prime} \mathrm{S}$ & $113^{\circ} 20^{\prime} 08^{\prime \prime} \mathrm{E}$ & Carrarang & Birrida \\
\hline $\mathrm{CB} 16^{*}+$ & Un-named birrida & $26^{\circ} 14^{\prime} 20^{\prime \prime S}$ & $113^{\circ} 23^{\prime} 56^{\prime \prime} \mathrm{E}$ & Carrarang & Birrida \\
\hline CB20*t & Hamelin Pool & $26^{\circ} 25^{\prime} 40^{\prime \prime} \mathrm{S}$ & $114^{\circ} 11^{\prime} 33^{\prime \prime} \mathrm{E}$ & Hamelin & Permanent swamp \\
\hline CB25* & Un-named claypan & $26^{\circ} 02^{\prime} 07^{\prime \prime S}$ & $114^{\circ} 19^{\prime} 50^{\prime \prime} \mathrm{E}$ & Yaringa & Ephemeral pan \\
\hline CB27a t & Nr Wardawarra Pool & $26^{\circ} 04^{\prime} 49^{\prime \prime} \mathrm{S}$ & $115^{\circ} 27^{\prime} 10^{\prime \prime} \mathrm{E}$ & Yalardy & River pool \\
\hline CB27b\#t & Un-named swamp & $26^{\circ} 15^{\prime 2} 22^{\prime \prime S}$ & $115^{\circ} 27^{\prime} 49^{\prime \prime} \mathrm{E}$ & Talisker & Ephemeral swamp \\
\hline CB27ct & Un-named swamp & $26^{\circ} 18^{\prime} 54^{\prime \prime} \mathrm{S}$ & $115^{\circ} 30^{\prime} 50^{\prime \prime} \mathrm{E}$ & Talisker & Ephemeral swamp \\
\hline CB29a* & Pan N of Big Lagoon & $25^{\circ} 36^{\prime} 01^{\prime \prime S}$ & $113^{\circ} 28^{\prime} 10^{\prime \prime} \mathrm{E}$ & Marine Park & Birrida \\
\hline CB30\#+ & Nr Namararra Well & $25^{\circ} 39^{\prime} 30^{\prime \prime} \mathrm{S}$ & $114^{\circ} 25^{\prime} 20^{\prime \prime} \mathrm{E}$ & Wooramel & River pool \\
\hline CB34*t & Mundilya Pool & $25^{\circ} 39^{\prime} 54^{\prime \prime} \mathrm{S}$ & $114^{\circ} 50^{\prime} 54^{\prime \prime} \mathrm{E}$ & Meedo & River pool \\
\hline CB35a* & Un-named canegrass pan & $25^{\circ} 40^{\prime} 52^{\prime \prime} \mathrm{S}$ & $114^{\circ} 13^{\prime} 14^{\prime \prime} \mathrm{E}$ & Wooramel & Ephemeral canegrass pan \\
\hline CB36* & Ephemeral marsh & $24^{\circ} 57^{\prime} 51^{\prime \prime} \mathrm{S}$ & $113^{\circ} 42^{\prime} 16^{\prime \prime} \mathrm{E}$ & Brickhouse & Ephemeral coastal marsh pan \\
\hline CB38*t & Chagra Well claypan & $25^{\circ} 11^{\prime} 47^{\prime \prime} \mathrm{S}$ & $114^{\circ} 57^{\prime} 02^{\prime \prime E}$ & Jimba Jimba & Ephemeral pan \\
\hline CB38a*t & Salt Gully & $25^{\circ} 04^{\prime} 17^{\prime \prime} \mathrm{S}$ & $115^{\circ} 01^{\prime} 48^{\prime \prime} \mathrm{E}$ & Jimba Jimba & River pool \\
\hline $\mathrm{CB} 42^{*}+$ & Winnemia Pool & $25^{\circ} 00^{\prime} 32^{\prime \prime} \mathrm{S}$ & $114^{\circ} 56^{\prime} 52^{\prime \prime E}$ & Jimba Jimba & River pool \\
\hline $\mathrm{CB} 43^{*}$ & Un-named claypan & $25^{\circ} 04^{\prime} 17^{\prime \prime} \mathrm{S}$ & $115^{\circ} 03^{\prime} 30^{\prime \prime} \mathrm{E}$ & Jimba Jimba & Ephemeral pan \\
\hline $\mathrm{CB} 44^{*}$ & Rocky Pool & $25^{\circ} 45^{\prime} 23^{\prime \prime} \mathrm{S}$ & $114^{\circ} 08^{\prime} 08^{\prime \prime} \mathrm{E}$ & Brickhouse & River pool \\
\hline $\mathrm{CB} 49^{*} \mathbf{t}$ & Coollilee Pool & $24^{\circ} 42^{\prime} 21^{\prime \prime S}$ & $113^{\circ} 41^{\prime} 10^{\prime \prime} \mathrm{E}$ & Boolathana & River pool \\
\hline CB51\#+ & Un-named canegrass pan & $24^{\prime} 44^{\prime} 21^{\prime \prime S}$ & $113^{\circ} 43^{\prime} 14^{\prime \prime E}$ & Boolathana & Ephemeral canegrass pan \\
\hline CB54*+ & Nr Cardabia Swamp & $24^{\circ} 33^{\prime} 10^{\prime \prime} \mathrm{S}$ & $113^{\circ} 45^{\prime} 35^{\prime \prime} \mathrm{E}$ & Boolathana & Canegrass swamp \\
\hline CB54a\# & Cardabia Swamp & $24^{\circ} 34^{\prime} 44^{\prime \prime} \mathrm{S}$ & $113^{\circ} 43^{\prime} 13 \mathrm{E}$ & Boolathana & Crabhole swamp \\
\hline $\mathrm{CB} 56^{*}+$ & Tirigie Claypan & $24^{\circ} 38^{\prime} 34^{\prime \prime} \mathrm{S}$ & $113^{\circ} 59^{\prime} 29^{\prime \prime} \mathrm{E}$ & Boolathana & Ephemeral pan \\
\hline CB56a* & Un-named pan & $24^{\circ} 38^{\prime} 19^{\prime \prime S}$ & $113^{\circ} 59^{\prime} 35^{\prime \prime E}$ & Boolathana & Ephemeral pan \\
\hline CB58b* & Un-riamed claypan & $24^{\circ} 48^{\prime} 08^{\prime \prime S}$ & $114^{\circ} 16^{\prime} 15^{\prime \prime S}$ & Doorawarrah & Ephemeral pan \\
\hline CB58 $c^{*}$ & Un-named bluebush swamp & $24^{\circ} 47^{\prime} 44^{\prime \prime} \mathrm{S}$ & $114^{\circ} 10^{\prime} 05^{\prime \prime} \mathrm{E}$ & Doorawarrah & Ephemeral bluebush swamp \\
\hline $\mathrm{CB} 8 \mathrm{~d}^{*}$ & Un-named canegrass pan & $24^{\circ} 47^{\prime} 37^{\prime \prime S}$ & $114^{\circ} 09^{\prime} 14^{\prime \prime} \mathrm{E}$ & Brickhouse & Ephemeral canegrass pan \\
\hline CB58 $\mathrm{e}^{*}$ & Un-named claypan & $24^{\circ} 47^{\prime} 35^{\prime \prime} \mathrm{S}$ & $114^{\circ} 09^{\prime} 14^{\prime \prime} \mathrm{E}$ & Brickhouse & Ephemeral pan \\
\hline $\mathrm{CB} 62^{*}+$ & Mooka Ruin springs & $24^{\circ} 53^{\prime} 26^{\prime \prime S}$ & $114^{\circ} 57^{\prime 2} 29^{\prime \prime E}$ & Mooka & River pool \\
\hline CB62a*t & Un-named creek & $24^{\circ} 46^{\prime} 28^{\prime \prime S}$ & $114^{\circ} 56^{\prime} 17^{\prime \prime E}$ & Mooka & River pool \\
\hline $\mathrm{CB} 62 \mathrm{~b}+$ & Lake Julia & $24^{\circ} 40^{\prime} 46^{\prime \prime S}$ & $114^{\circ} 56^{\prime} 11^{\prime \prime E}$ & Mooka & Ephemeral swamp \\
\hline $\mathrm{CB} 62 \mathrm{c}^{*} \mathbf{t}$ & Un-named spring & $24^{\circ} 46^{\prime} 31^{\prime \prime S}$ & $114^{\circ} 56^{\prime} 20^{\prime \prime} \mathrm{E}$ & Mooka & Hillside seep \\
\hline CB67a*t & Birdrong Spring & $24^{\circ} 14^{\prime} 40^{\prime \prime S}$ & $114^{\circ} 52^{\prime} 11^{\prime \prime} \mathrm{E}$ & Mardathuna & Hillside seep \\
\hline CB67b*t & Scooped Hole & $24^{\circ} 18^{\prime} 07^{\prime \prime S}$ & $114^{\circ} 50^{\prime} 28^{\prime \prime} \mathrm{E}$ & Mardathuna & River pool \\
\hline CB68* & Un-named swamp & $24^{\circ} 17^{\prime} 46^{\prime \prime} \mathrm{S}$ & $114^{\circ} 29^{\prime} 47^{\prime \prime} \mathrm{E}$ & Hill Springs & Ephemeral swamp \\
\hline CB70b*t & Bulgra Pool & $24^{\circ} 25^{\prime} 41^{\prime \prime S}$ & $114^{\circ} 32^{\prime} 54^{\prime \prime} \mathrm{E}$ & Mardathuna & River pool \\
\hline CB73*t & Boolan Pool & $24^{\circ} 28^{\prime} 38^{\prime \prime} \mathrm{S}$ & $113^{\circ} 40^{\prime} 36^{\prime \prime} \mathrm{E}$ & Boolathana & River pool \\
\hline CB75a*t & Cattle Camp Pan & $24^{\circ} 28^{\prime} 25^{\prime \prime} \mathrm{S}$ & $114^{\circ} 13^{\prime} 27^{\prime \prime} \mathrm{E}$ & Cooralya & Ephemeral pan \\
\hline CB75b*t & Bluebush Bore Swamp & $24^{\circ} 28^{\prime} 19^{\prime \prime} \mathrm{S}$ & $114^{\circ} 18^{\prime} 08^{\prime \prime} \mathrm{E}$ & Cooralya & Bluebush swamp \\
\hline CB75c* & Dwyers Pan & $24^{\circ} 26^{\prime} 00^{\prime \prime} \mathrm{S}$ & $114^{\circ} 27^{\prime} 18^{\prime \prime} \mathrm{E}$ & Mardathuna & Ephemeral pan \\
\hline CB76*+ & Lake McLeod & $23^{\circ} 57^{\prime} 39^{\prime \prime} \mathrm{S}$ & $113^{\circ} 36^{\prime} 40^{\prime \prime} \mathrm{E}$ & Gnaraloo/Dampier Salt & Birrida \\
\hline CB77*t & Lake McLeod & $23^{\circ} 54^{\prime} 53^{\prime \prime S}$ & $113^{\circ} 39^{\prime} 23^{\prime \prime} \mathrm{E}$ & Gnaraloo/Dampier Salt & Birrida \\
\hline CB78 & Lake McLeod & $23^{\circ} 52^{\prime} 19^{\prime \prime S}$ & $113^{\circ} 42^{\prime} 43^{\prime \prime} \mathrm{E}$ & Gnaraloo/Dampier Salt & Marine pan \\
\hline CB79 + & Lake McLeod (Blue Holes) & $23^{\circ} 47^{\prime} 16^{\prime \prime S}$ & $113^{\circ} 44^{\prime} 44^{\prime \prime} \mathrm{E}$ & Gnaraloo/Dampier salt & Marine pan \\
\hline $\mathrm{CB} 82^{*}+$ & Minilya Pool & $23^{\circ} 52^{\circ} 04^{\prime \prime} \mathrm{S}$ & $113^{\circ} 58^{\prime} 44^{\prime \prime} \mathrm{E}$ & Minilya & River pool \\
\hline $\mathrm{CB}^{2 *+}$ & Cardilya Pool & $25^{\circ} 37^{\prime} 34^{\prime \prime S}$ & $115^{\circ} 31^{\prime} 28^{\prime \prime} \mathrm{E}$ & Carey Downs & River pool \\
\hline CB93a*t & Bidgelang Pool & $25^{\circ} 34^{\prime} 32^{\prime \prime} \mathrm{S}$ & $115^{\circ} 36^{\prime} 01^{\prime \prime} \mathrm{E}$ & Carey Downs & River pool \\
\hline CB93ct & Callytharra Spring & $25^{\circ} 52.59^{\prime \prime} \mathrm{S}$ & $115^{\circ} 30.14^{\prime \prime} \mathrm{E}$ & Carey Downs & River pool \\
\hline CB93d*t & Nunnery Pool & $25^{\circ} 51^{\prime} 45^{\prime \prime S}$ & $115^{\circ} 31^{\prime} 53^{\prime \prime} \mathrm{E}$ & Carey Downs & River pool \\
\hline CB93f*t & Boothawalla Pool & $25^{\circ} 47^{\prime} 31^{\prime \prime S}$ & $115^{\circ} 17^{\prime} 26^{\prime \prime} \mathrm{E}$ & Carey Downs & River pool \\
\hline CB93g* & Meedo Pool & $25^{\circ} 44^{\prime} 29^{\prime \prime} \mathrm{S}$ & $115^{\circ} 06^{\prime} 59^{\prime \prime} \mathrm{E}$ & Gilroyd & River pool \\
\hline
\end{tabular}




\section{Appendix 2}

Values of environmental variables collected in the southern Carnarvon Basin in winter and summer. See text for description of variables.

\begin{tabular}{|c|c|c|c|c|c|c|c|c|c|c|c|c|c|c|c|c|}
\hline 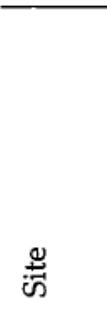 & 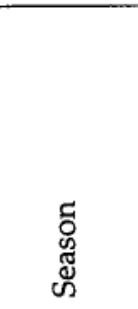 & 焉 & 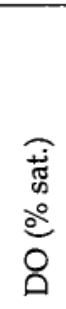 & 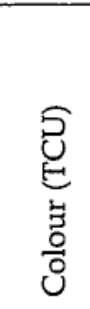 & 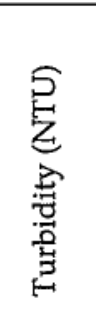 & 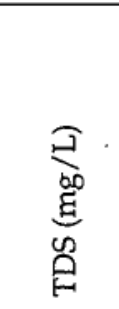 & 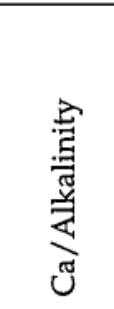 & 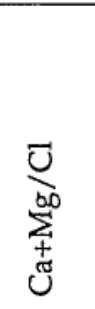 & $\underset{0}{0}$ & 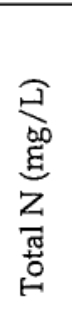 & 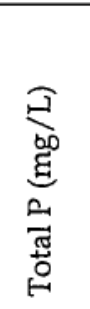 & 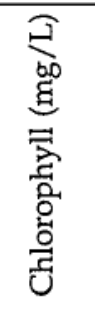 & $\mathrm{O}^{n}$ & 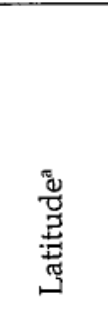 & 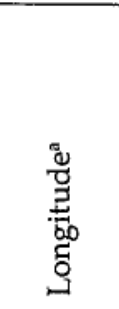 & है \\
\hline B04 & summer & 7.7 & 85 & 63 & 310 & 300 & 507 & 391 & 833 & 0.68 & 0.08 & 0.005 & 0.6 & & 68 & \\
\hline B04 & winter & 8 & 98 & 14 & 0.24 & 3600 & 1.035 & 265 & 0.582 & 0.39 & 0.01 & 0.002 & & & 14.568 & \\
\hline B05 & su & 6.2 & 83 & 77 & 280 & 260 & 0.468 & 0.926 & 1.917 & 0.75 & 0.06 & 0.007 & 11 & 27.818 & 114.775 & \\
\hline B05 & winter & 8 & 110 & 8 & 2 & 1100 & 1.097 & 0.286 & 0.675 & 0.41 & 0 & 0.007 & & 27.818 & 114.775 & \\
\hline B06a & winter & 8.3 & 120 & 14 & 0.76 & 23 & 0.196 & 0.669 & 4.793 & 0.44 & 0.01 & 0.006 & & 27.524 & 115.072 & \\
\hline $\mathrm{B} 06 \mathrm{~b}$ & summer & 7.5 & 68 & 1200 & 62000 & 1100 & 0.060 & 0.377 & 0.872 & & & & 76 & 27.525 & 115.087 & 1 \\
\hline $\mathrm{B} 06 \mathrm{~b}$ & winter & 7.4 & 108 & 1100 & 17000 & 84 & 0.217 & 0.203 & 1.917 & 3.4 & 0.01 & 0.005 & & 27.525 & 115.087 & 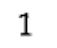 \\
\hline B09 & sum & 7 & $?$ & 50 & 15 & 2000 & & 228 & 0.415 & 0.53 & 0.04 & 0.024 & 6.7 & & 709 & 1 \\
\hline B09 & winter & 7.8 & 106 & 3 & 0.91 & 180000 & & 186 & 0.370 & 2.1 & 0.01 & 0.004 & & & 709 & 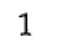 \\
\hline $\mathrm{B} 09 \mathrm{a}$ & winter & 8.6 & 126 & 23 & 0.85 & 85000 & & 269 & 0.543 & 3.2 & 0.02 & 0.002 & & 42 & 710 & \\
\hline B15 & summer & 7.8 & 77 & 39 & 5.1 & 140000 & 18.994 & 0.197 & 0.411 & 1.6 & 0.02 & 0.147 & 3 & 26.385 & 336 & \\
\hline B15 & winter & 8 & 85 & 3 & 0.45 & 57000 & 34.043 & 0.286 & 0.657 & 2.1 & 0.01 & 0.015 & & 26.385 & 113.336 & \\
\hline BB16 & & 7.7 & 71 & 200 & 20 & 270000 & 6.596 & 0.195 & 0.186 & 1.2 & 0.005 & 0 & 7.4 & 26.239 & 3.399 & \\
\hline CB16 & win & 8.1 & 119 & 5 & 0.5 & 55000 & 44.907 & 0.282 & 0.719 & 1 & 0.02 & 0.002 & & & & \\
\hline CB20 & summer & 7.6 & 40 & 36 & 3.6 & 6300 & 2.537 & 0.258 & 0.513 & 0.24 & 0.005 & 0.004 & 9.6 & 26.428 & 114.193 & 2 \\
\hline CB20 & winter & 8.2 & 167 & & 0.3 & 6000 & 2.585 & 0.264 & 0.568 & 0.35 & 0.01 & 0.001 & & 26. & 93 & 2 \\
\hline B25 & win & & 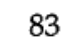 & & & 90000 & & 0.159 & & & & & & & & 1 \\
\hline 7a & & 8 & 77 & 5 & 250 & 310 & 1 & 266 & 2 & 0.87 & & 0 & 6.9 & & & 2 \\
\hline $27 \mathrm{~b}$ & & 6.7 & 75 & 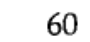 & 300 & 150 & 03 & 71 & 2.397 & 0.67 & 0.07 & 0.015 & 1.9 & & 64 & 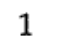 \\
\hline $\mathrm{CB} 27 \mathrm{~b}$ & wir & 7.38 & 2 & 34 & 440 & 45 & 0.127 & 0.323 & 0.799 & 1.7 & 0.11 & 0.25 & & 56 & 64 & \\
\hline CB27c & st & 7.5 & 78 & 51 & 26 & 1700 & 4.154 & 334 & 1.046 & 4.2 & 0.04 & 0.092 & 1.3 & & 14 & \\
\hline CB29a & winter & 8.6 & 139 & 7 & 0.5 & 94000 & 38.521 & 0.267 & 0.530 & 2.2 & 0.02 & 0.017 & & 00 & .470 & 1 \\
\hline CB30 & & 8.6 & 110 & 17 & 3.5 & 150 & 0.780 & 2.325 & 2.820 & 0.21 & 0.01 & 0.003 & 8 & & 422 & \\
\hline CB30 & winter & 8.91 & 102 & 24 & 1.1 & 110 & 11 & 2.611 & 4.622 & 0.54 & 0.01 & 0.11 & & & 122 & \\
\hline CB34 & & & 9 & 15 & 1.5 & 260 & 39 & 04 & 2.242 & 0.31 & 0.01 & 0.004 & 9 & & & \\
\hline CB34 & & 9.4 & & 7 & & & & & & 0.69 & 0.01 & 0.014 & & & & \\
\hline CB35a & wir & 7.8 & 68 & 5 & 0 & 480 & 1 & 23 & 2.397 & 0.84 & 0.24 & & & 81 & 21 & 1 \\
\hline B36 & & 8 & & 40 & & 63 & 75 & 10 & 0.399 & 1.1 & 0.67 & 0.027 & & 64 & 55 & 1 \\
\hline 38 & & & 8 & 12 & & 37 & 76 & 6 & 0 & 1.2 & 0. & & 2 & & & 1 \\
\hline 8 & & & & 400 & J & 19 & 60 & 7 & 0. & 1.6 & 0 . & & & & & 1 \\
\hline $8 \mathrm{a}$ & & 8 & 8 & 8 & & 1400 & 3 & 32 & 23 & 0.41 & 0.01 & 0.02 & 4.3 & 71 & & \\
\hline CB38a & & 9.1 & 115 & 6 & 8 & 0 & 24 & 02 & 71 & 0.28 & 0.01 & 0.001 & & 71 & 30 & \\
\hline CB42 & & 8.1 & 0 & 12 & 5.1 & 660 & & 0.730 & 1.289 & 0.17 & 0.005 & 0.003 & 7.8 & 09 & & \\
\hline CB42 & & 8.6 & 7 & 5 & & 1700 & & 0.434 & 0.767 & 0.45 & 0 & 0.002 & & & & \\
\hline CB43 & & 8. & 95 & 180 & 36000 & & & & 0.799 & 1.5 & 39 & 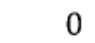 & & & & \\
\hline CB44 & & 8.6 & & 7 & & & & & 96 & 0.58 & 0 & 001 & & & & 2 \\
\hline & & 6. & & 11 & & & & 76 & 1.525 & 0.82 & 0.21 & 0.036 & 16 & & 86 & 1 \\
\hline 19 & & & & & & & & 3 & 0.737 & 1.3 & 0. & 0.008 & & & & 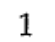 \\
\hline & & & & & & & & & & 0.62 & 0.35 & & 7.4 & & & 1 \\
\hline 1 & & 8.44 & 104 & & & & & 68 & 33 & 1.5 & 0.33 & 0.078 & & 39 & 21 & \\
\hline CB54 & & 8.2 & 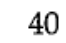 & 91 & 50000 & & 76 & 0.079 & 0.409 & 5 & 0.96 & & 2.8 & 24.553 & .760 & \\
\hline CB54 & & 8.2 & 9. & 1400 & 12000 & & & 0.138 & 0.369 & 1.8 & 0.05 & & & 24.553 & & \\
\hline CB54a & & 6.5 & 5 & 35 & & & 0.254 & 2.228 & 14.380 & 0.81 & 0.03 & 0.015 & & 24.579 & 720 & \\
\hline CB56 & & 7. & 8 & 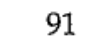 & 4500 & 55 & 00 & 2.672 & 5.592 & 1.7 & 0.1 & 0.05 & 20 & 43 & & \\
\hline & & 8 & & & & 5 & & & 2.996 & 0.43 & 0.06 & 0.02 & & & & 1 \\
\hline $56 a$ & & 7.4 & & 12000 & 8000 & 500 & & & 8.788 & 3.9 & & 0 & & & & 1 \\
\hline & & -1 & & 1900 & 43000 & 250 & & & & 3.1 & & 0 & & 02 & 271 & \\
\hline & & & & & & 6 & & & & 0.77 & 0.03 & 0.003 & & 96 & 168 & \\
\hline CB58d & & 9. & 156 & 780 & 880 & 91 & & 0.339 & 1.198 & 1.9 & 0.01 & 0.015 & & 24.794 & 114.154 & \\
\hline CB58e & winter & 8.2 & 104 & 8800 & 22000 & 680 & 0.056 & 0.304 & 1.798 & 2.4 & 1.5 & 0 & & 24.793 & 114.154 & \\
\hline CB62 & summe & 8.3 & 150 & 120 & 17 & 11000 & 2.176 & 0.477 & 0.412 & 2.8 & 0.01 & 0.006 & 25 & 24.891 & 114.958 & \\
\hline CB62 & & 7. & 7 & & 0.45 & 00 & & 0.513 & 0.472 & 0.51 & 0.01 & 0 & & 24.891 & 114.958 & 4 \\
\hline & & 8. & & 76 & 2.9 & & 0.733 & 0.396 & 0.257 & 0.99 & 0.01 & 0.007 & 64 & 24.774 & 114.938 & 4 \\
\hline CB62a & winter & 8.8 & 158 & 23 & 0.34 & 10000 & 1.120 & 0.387 & 0.194 & 0.68 & 0 & 0.006 & & 24.774 & 114.938 & 4 \\
\hline
\end{tabular}




\begin{tabular}{|c|c|c|c|c|c|c|c|c|c|c|c|c|c|c|c|c|}
\hline 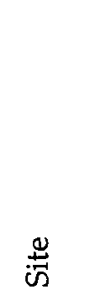 & 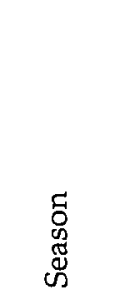 & 空 & 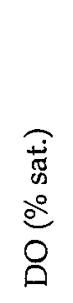 & 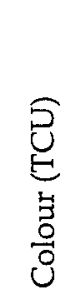 & 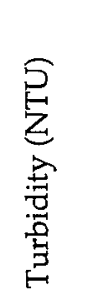 & $\begin{array}{l}\widehat{\Xi} \\
\stackrel{\infty 0}{0} \\
\stackrel{E}{E} \\
\mathscr{D} \\
E\end{array}$ & 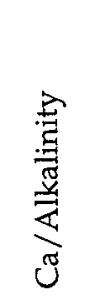 & $\begin{array}{l}\bar{U} \\
\underset{\sum^{\infty 0}}{+} \\
\mathbb{U}\end{array}$ & 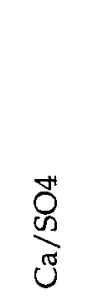 & 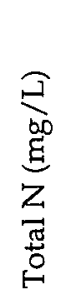 & 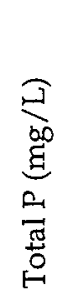 & 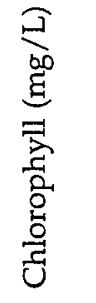 & $\stackrel{D}{n}^{N}$ & 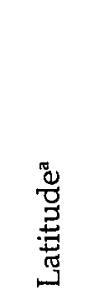 & 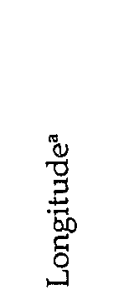 & $\frac{2}{3}$ \\
\hline $\mathrm{CB} 62 \mathrm{~b}$ & summer & 7.6 & 70 & 490 & 3100 & 400 & 0.145 & 1.013 & 1.198 & 3.7 & 0.01 & & 22 & 24.68 & 114.936 & 1 \\
\hline CB67a & summer & 6.4 & 10 & 13 & 21 & 1200 & 1.796 & 1.047 & 0.474 & 0.47 & 0.21 & 0.034 & 15 & 24.244 & 114.870 & 3 \\
\hline CB67a & winter & 6.9 & 68 & 8 & 0.21 & 1300 & 1.921 & 1.029 & 0.499 & 0.91 & 0 & 0.012 & & 24.244 & 114.870 & 3 \\
\hline $\mathrm{CB} 67 \mathrm{~b}$ & summer & 8.6 & 138 & 24 & 0.7 & 7200 & 1.211 & 0.534 & 0.234 & 0.43 & 0.01 & 0.005 & 16 & 24.302 & 114.841 & 4 \\
\hline $\mathrm{CB} 67 \mathrm{~b}$ & winter & 8.2 & 145 & 12 & 0.34 & 6500 & 1.473 & 0.607 & 0.288 & 0.64 & 0 & 0.016 & & 24.302 & 114.841 & 4 \\
\hline CB68 & winter & 8.1 & 110 & 140 & 400 & 43 & 0.435 & 2.933 & 1.332 & 0.53 & 0.02 & 0.009 & & 24.296 & 114.497 & 1 \\
\hline CB70b & summer & 9.4 & 120 & 80 & 250 & 300 & 1.217 & 0.894 & 1.667 & 2.2 & 0.06 & 0.14 & 24 & 24.428 & 548 & 1 \\
\hline CB70b & winter & 7.8 & 101 & 1100 & 1400 & 74 & 0.294 & 1.278 & 2.397 & 5.5 & 0.64 & 0.134 & & 24.428 & 114.548 & 1 \\
\hline CB73 & summer & 8.8 & 94 & 160 & 960 & 3000 & 0.238 & 0.145 & 0.723 & 7 & 1.1 & 0.042 & 15 & 24.477 & 113.677 & 1 \\
\hline CB73 & winter & 8.5 & 97 & 1000 & 2300 & 240 & 0.071 & 0.507 & 1.370 & 4.5 & 0.56 & 0.113 & & 24.477 & 113.677 & 1 \\
\hline CB75a & summer & 7.5 & 72 & 810 & 30000 & 1200 & 0.069 & 0.857 & 0.799 & 6 & 5.1 & & 20 & 24.474 & 114.224 & 1 \\
\hline CB75a & winter & 8.2 & 110 & 2300 & 2700 & 91 & 0.124 & 0.954 & 1.198 & 2.1 & 1.5 & 0.047 & & 24.474 & 114.224 & 1 \\
\hline CB75b & summer & 8 & 121 & 160 & 1500 & 730 & 0.254 & 4.686 & 9.587 & 1 & 0.15 & 0.076 & 39 & 24.472 & 114.302 & 1 \\
\hline CB75b & winter & 7.5 & 84 & 550 & 1400 & 76 & 0.315 & 1.886 & 3.595 & 1.5 & 0.06 & 0.012 & & 24.472 & 114.302 & 1 \\
\hline CB75c & winter & 7.2 & 104 & 460 & 700 & 53 & 0.434 & 0.551 & 0.599 & 1.5 & 0.07 & 0.011 & & 24.433 & 114.455 & 1 \\
\hline CB76 & summer & 7.9 & 152 & 13 & 3.6 & 53000 & 9.465 & 0.223 & 0.382 & 0.55 & 0.01 & 0.005 & 20 & 23.961 & 113.611 & 1 \\
\hline CB76 & winter & 8.2 & 147 & 9 & 0.26 & 46000 & 9.032 & 0.219 & 0.404 & 0.51 & 0.01 & 0.002 & & 23.961 & 113.611 & 1 \\
\hline CB77 & summer & 7.8 & 164 & 14 & 4.8 & 41000 & 7.811 & 0.242 & 0.386 & 0.24 & 0.005 & 0.01 & 3.9 & 23.915 & 113.656 & 1 \\
\hline CB77 & winter & 8.9 & 145 & 5 & 0.21 & 40000 & 8.318 & 0.237 & 0.402 & 0.31 & 0 & 0.02 & & 23.915 & 113.656 & 1 \\
\hline CB78 & winter & 7.4 & 133 & 8 & 0.05 & 32460 & 7.402 & 0.268 & 0.608 & 0.85 & 0.005 & & & 23.872 & 113.712 & 1 \\
\hline CB79 & summer & 7.2 & 84 & 17 & 0.6 & 40000 & 5.419 & 0.242 & 0.416 & 0.28 & 0.005 & 0 & 3.2 & 23.788 & 113.746 & 1 \\
\hline CB79 & winter & 7.3 & 105 & 12 & 0.05 & 41220 & 7.088 & 0.267 & 0.375 & 0.48 & 0.005 & & & 23.788 & 113.746 & 1 \\
\hline CB82 & summer & 6.9 & 74 & 21 & 540 & 140 & 0.741 & 5.356 & 2.846 & 0.41 & 0.06 & 0.017 & 6.3 & 23.868 & 113.979 & 2 \\
\hline CB82 & winter & 8.8 & 84 & 110 & 100 & 340 & 0.676 & 0.977 & 2.538 & 0.56 & 0.02 & 0.026 & & 23.868 & 113.979 & 2 \\
\hline CB93 & summer & 8 & 109 & 28 & 0.7 & 80 & 0.456 & 4.112 & 7.190 & 0.41 & 0.01 & 0.009 & 6.9 & 25.626 & 115.524 & 2 \\
\hline CB93 & winter & 8.8 & 102 & 24 & 1.7 & 180 & 0.692 & 5.289 & 23.967 & 2.8 & 0.01 & 0.04 & & 25.626 & 115.524 & 2 \\
\hline CB93a & summer & 8.4 & 108 & 23 & 1.4 & 120 & 0.609 & 2.395 & 6.591 & 0.44 & 0.01 & 0.006 & 11 & 25.576 & 115.600 & 2 \\
\hline CB93a & winter & 7.7 & 106 & 13 & 0.28 & 64 & 0.537 & 1.210 & 4.793 & 0.55 & 0 & 0.002 & & 25.576 & 115.600 & 2 \\
\hline CB93c & summer & 7.6 & 99 & 15 & 6.9 & 590 & 1.522 & 1.023 & 1.065 & 0.18 & 0.005 & 0.014 & 6.2 & 25.877 & 115.502 & 4 \\
\hline CB93c & winter & 8.4 & 108 & 7 & 0.25 & 1700 & 1.416 & 0.590 & 0.799 & 0.23 & 0 & 0.001 & & 25.877 & 115.502 & 4 \\
\hline CB93d & summer & 8.1 & 99 & 11 & 16 & 310 & 1.416 & 1.414 & 1.031 & 0.24 & 0.005 & 0.014 & 6.6 & 25.863 & 115.531 & 2 \\
\hline CB93d & winter & 8.7 & 142 & 7 & 0.25 & 580 & 1.332 & 1.103 & 1.174 & 0.48 & 0 & 0.001 & & 25.863 & 115.531 & 2 \\
\hline CB93f & summer & 8.3 & 89 & 14 & 3.4 & 680 & 1.712 & 1.033 & 1.027 & 0.28 & 0.005 & 0.009 & 6 & 25.792 & 115.291 & 4 \\
\hline CB93f & winter & 8.4 & 108 & 17 & 0.25 & 420 & 0.832 & 1.179 & 3.414 & 0.78 & 0.01 & 0.026 & & 25.792 & 115.291 & 2 \\
\hline CB93g & winter & 9.5 & 161 & 10 & 0.31 & 480 & 0.949 & 1.022 & 1.580 & 0.72 & 0.01 & 0.03 & & 25.741 & 115.116 & 2 \\
\hline
\end{tabular}

a decimal degrees

b flow category 


\section{Appendix 3}

Waterbirds recorded at wetlands in the southern Carnarvon Basin 1994-95. See Appendix 1 for wetland site names.

\begin{tabular}{|c|c|c|c|c|c|c|c|c|c|c|c|c|c|c|c|c|c|c|c|c|c|c|c|c|c|c|c|}
\hline Species & 蒿 & 总 & 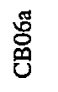 & 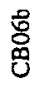 & 吕 & $\begin{array}{l}\text { g̊ } \\
\text { ᄋ̊ }\end{array}$ & $\frac{n}{0}$ & $\frac{0}{8}$ & 尽 & ণ్ & స્ّ & 荵 & $\begin{array}{l}\stackrel{0}{D} \\
\tilde{0}\end{array}$ & 芯 & 怘 & 志 & ஜึ & 怘 & $\stackrel{\infty}{\tilde{ల}}$ & 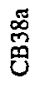 & 等 & 䓌 & 志 & 离 & $\stackrel{\vec{n}}{\tilde{u}}$ & 芯 & $\begin{array}{l}\text { 志 } \\
\text { 品 }\end{array}$ \\
\hline Black Swan & & 4 & & & & & & & 11 & & & & & & & & & & & & 2 & & 1 & & & & \\
\hline Australian Shelduck & 4 & 4 & 1 & & & & & & 17 & & & & & & & & & & & & & & & & & & \\
\hline Australian Wood Duck & & 4 & 1 & 20 & & & & & 2 & & & 4 & & & & & & & 7 & & & & 4 & & & & \\
\hline Pacific Black Duck & 1 & 8 & 6 & 3 & & & & & 56 & & & & & & & & & & & & 1 & & & & & & \\
\hline Australasian Shoveler & & & & & & & & & 1 & & & & & & & & & & & & & & & & & & \\
\hline Grey Teal & & & 17 & 10 & & & & & 34 & & & 7 & & & & & & & 18 & 5 & 11 & & 2 & & 4 & 9 & \\
\hline Pink-eared Duck & & & 2 & & & & & & & & & 4 & & & & & & & 3 & & & & & & & 3 & \\
\hline Hardhead & 3 & & & & & & & & & & & & & & & & & & & & & & & & & & \\
\hline Unidentified duck & & & & & & & & & & & & & & & & & & & & & & & & & & & \\
\hline Australasian Grebe & 1 & 3 & 6 & & & & & & 3 & & & & & & & & & & & & & & & & & & \\
\hline Hoary-headed Grebe & & 1 & 3 & & & & & & 5 & & & 7 & & & & & & & & & & & 2 & & & & \\
\hline Great Crested Grebe & & & & & & & & & & & & & & & & & & & & & & & & & & & \\
\hline Unidentified grebe & & 9 & & & & & & & 8 & & & & & & & & & & & & & & & & & & \\
\hline Darter & & 2 & & & & & & & & & & & & & & & & & & & 1 & & & & & & \\
\hline Little Pied Cormorant & & 2 & & & & & & & 1 & & & & & & & & & & & & 2 & & & & & & \\
\hline Pied Cormorant & & & & & & & & & & & & & & & & & & & & & & & & & & & \\
\hline Little Black Cormorant & 2 & & & & & & & & & & & & & & & & & & & & 1 & & 8 & & & & \\
\hline Unidentified cormorant & & & & & & & & & & & & & & & & & & & & & & & & & & & \\
\hline Australian Pelican & & & & & & & & & & & & & & & & & & & & & & & & & & & \\
\hline White-faced Heron & & & 2 & 9 & & & & & 2 & & & 1 & & & & & & 1 & 6 & & 3 & & & & & 2 & \\
\hline Little Egret & & & & & & & & & & & & & & & & & & & & & & & & & & & \\
\hline White-necked Heron & & & & 1 & & & & & & & & & & & & & 2 & & & & 3 & & & & & 1 & \\
\hline Great Egret & 1 & & 1 & & & & & & & & & & & & & & & & & & 2 & & 1 & & & & \\
\hline $\begin{array}{l}\text { Unidentified egret } \\
\text { Striated Heron }\end{array}$ & & & & & & & & & & & & & & & & & & & & & & & & & & & \\
\hline $\begin{array}{l}\text { Striated Heron } \\
\text { Nankeen Night Heron }\end{array}$ & & & & & & & & & & & & & & & & & & & & & & & & & & & \\
\hline Straw-necked Ibis & & & 6 & & & & & & & & & & & & & & & & & & 9 & & & & & & \\
\hline Royal Spoonbill & & & & & & & & & & & & & & & & & & & & & & & & & & & \\
\hline Yellow-billed Spoonbill & & & 1 & & & & & & & & & & & & & & & & & & 1 & & & & & & \\
\hline White-bellied Sea-eagle & & & & & & & & & & & & & & & & & & & & & & & & & & & \\
\hline Buff-banded Rail & & & & & & & & & 1 & & & & & & & & & & & & & & & & & & \\
\hline Baillon's Crake & & & & & & & & & 6 & & & & & & & & & & & & & & & & & & \\
\hline Dusky Moorhen & & & & 1 & & & & & & & & & & & & & & & & & & & & & & & \\
\hline Black-tailed Native-hen & & & & & & & & & & & & & & & & & 9 & & & & & & & 1 & & & \\
\hline Eurasian Coot & & 50 & & & & & & & 74 & & & & & & & & & & & & 6 & & 8 & & & & \\
\hline Bar-tailed Godwil & & & & & & & & & & & & & & & & & & & & & & & & & & & \\
\hline Whimbrel & & & & & & & & & & & & & & & & & & & & & & & & & & & \\
\hline Marsh Sandpiper & & & & & & & & & & & & & & & & & & & & & & & & & & & \\
\hline Common Greenshank & & & & & & & & 1 & & & & & & & & & & & & & & & & & & & \\
\hline $\begin{array}{l}\text { Terek Sandpiper } \\
\text { Common Sandpiper }\end{array}$ & & & & & & & & & & & & & & & & & & & & & & & & & & & \\
\hline $\begin{array}{l}\text { Common Sandpiper } \\
\text { Grey-tailed Tattler }\end{array}$ & 1 & & & & & & & & & & & & & & & & 1 & & & & & & 1 & 1 & & & \\
\hline $\begin{array}{l}\text { Grey-tailed Tattler } \\
\text { Ruddy Turnstone }\end{array}$ & & & & & & & & & & & & & & & & & & & & & & & & & & & \\
\hline Great Knot & & & & & & & & & & & & & & & & & & & & & & & & & & & \\
\hline Red-necked Stint & & & & & & & & & & & & & & 7 & & & & & & & & & & & & & \\
\hline Sharp-tailed Sandpiper & & & & & & & & & & & & & & & & & & & & & & & & & & & \\
\hline Curlew Sandpiper & & & & & & & & & & & & & & 15 & & & & & & & & & & & & & \\
\hline Pied Oystercatcher & & & & & & & & & & & & & & & & & & & & & & & & & & & \\
\hline Black-winged Stilt & & & & & & & & & 6 & & & & & & & & & & & & & & & & & & \\
\hline Banded Stilt & & & & & 80 & & 8 & & & & & & & 1250 & & & & & & & & & & & & & \\
\hline Red-necked Avocet & & & & & & & & & 1 & & & & & & & & & & 1 & & & & & & & & \\
\hline Pacific Golden Plover & & & & & & & & & & & & & & & & & & & & & & & & & & & \\
\hline Grey Plover & & & & & & & & & & & & & & & & & & & & & & & & & & & \\
\hline Red-capped Plover & & & & & 3 & & 13 & 1 & & 4 & & & & 13 & & & & & & & & & & & & & \\
\hline Greater Sand Plover & & & & & & & & & & & & & & & & & & & & & & & & & & & \\
\hline Black-fronted Dottere] & & & 2 & & & & & & 7 & & & & & & & 1 & & & 1 & 3 & 2 & & 2 & & & & \\
\hline Red-kneed Dotterel & & & & & & & & & & & & & & & & & 10 & & & & & & & & & & \\
\hline Banded Lapwing & & & & & & & & & & & & & & & & & & & & & & & & & & & \\
\hline Unidentified wader & & & & & & & & & & & & & & & & & & & & & & & & & & & \\
\hline Silver Gull & & & & & & & 1 & & & & & & & & & & & & & & & & & & & & \\
\hline Gull-billed Tern & & & & & & & 1 & & & & & & & & & & & & & & & & & & & & \\
\hline Caspian Tem & & & & & & & & & & & & & & & & & & & & & & & & & & & \\
\hline Unidentified Tern & & & & & & & & & & & & & & & & & & & & & & & & & & & \\
\hline No. of birds & 13 & 87 & 48 & 44 & 83 & 0 & 23 & 2 & 235 & 4 & 0 & 23 & 0 & 1285 & 0 & 1 & 22 & I & 36 & 8 & 44 & 0 & 29 & 2 & 4 & 15 & 0 \\
\hline No. of species & 7 & 10 & 12 & 6 & 2 & 0 & 4 & 2 & 17 & 1 & 0 & 5 & 0 & 4 & 0 & 1 & 4 & 1 & 6 & 2 & 13 & 0 & 9 & 2 & 1 & 4 & 0 \\
\hline
\end{tabular}


Aquatic fauna of the southern Carnarvon Basin

243

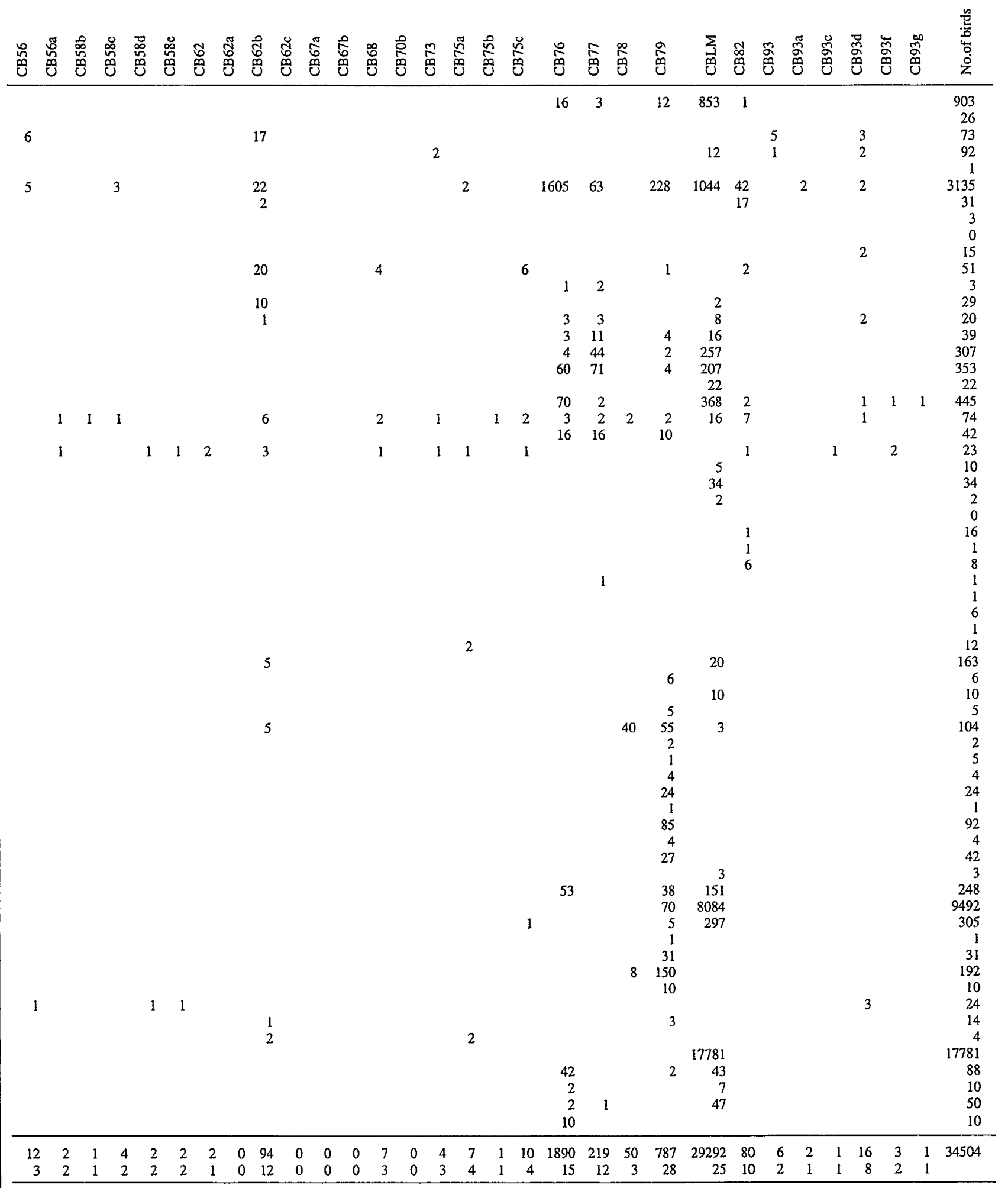




\section{Appendix 4}

Aquatic invertebrates collected during winter 1994 or 1995 and summer 1995 in the southern Carnarvon Basin. See Appendix 1 for wetland site names.

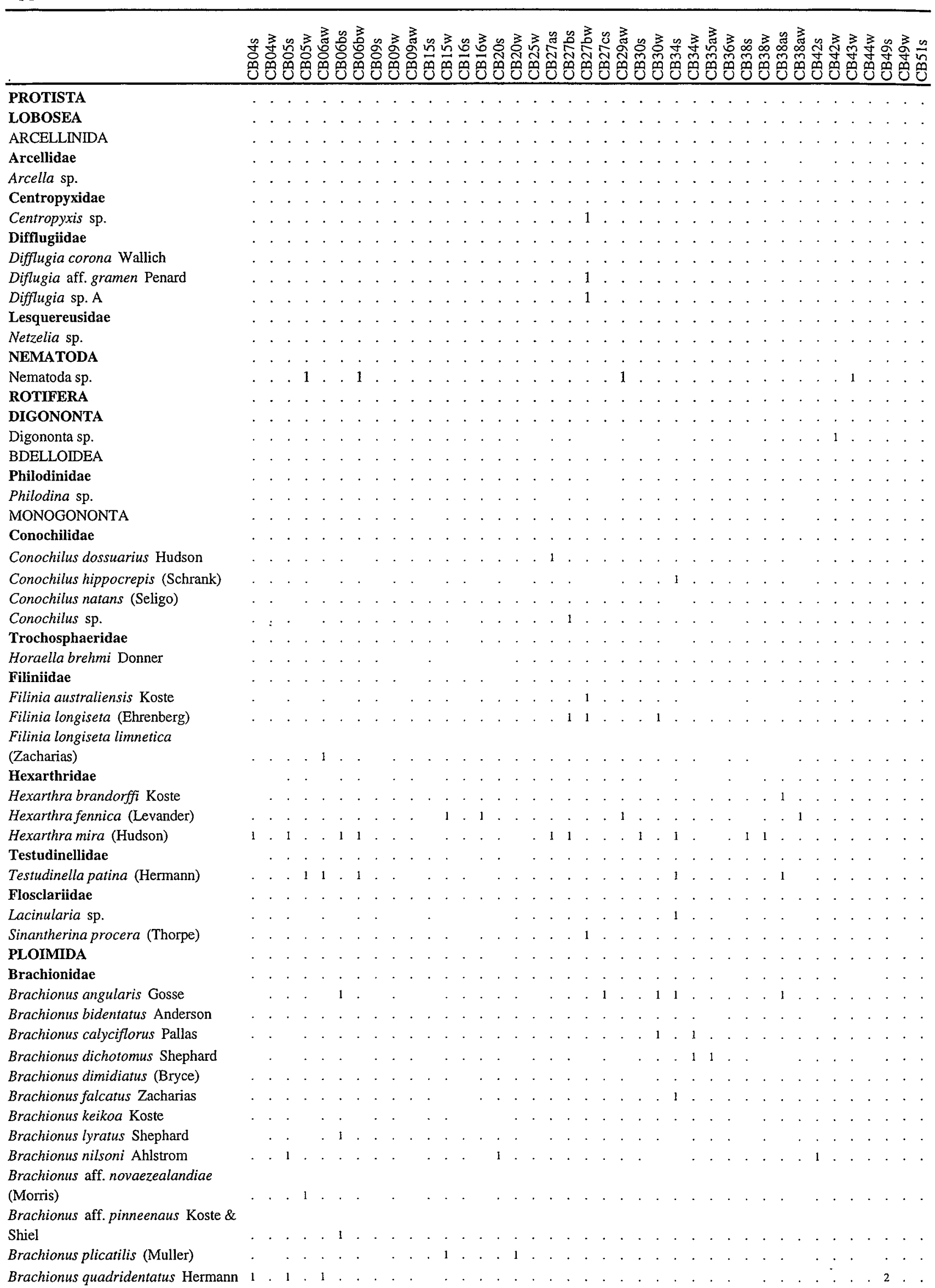


CB51w

CB54s

CB54w

CB54aw

CB56s

CB56w

CB56aw

CB58bw

CB58 cW

CB58dw

CB58ew

CB62w

CB62as

CB62aw

CB62bs

CB62cw

CB67as

CB67aw

CB67bs

CB67bw

CB68w

CB70bs

CB70bw

CB73s

CB73w

CB75as

CB75aw

CB75bs

CB75bw

CB75cw

CB76

CB76w

CB77s

CB77w

CB78w

CB79s
CB79w

CB82s

CB82w

CB82W

CB93s

CB93w

CB93as

CB93aw

CB93cs

CB93cw

CB93ds

CB93dw

CB93fs

CB93fw

CB93gw

Total 
Brachionus quadridentatus rhenanus

(Lauterborn)

Brachionus rubens Ehrenberg

Brachionus urceolaris (Mueller)

Brachionus sp.

Keratella australis (Berzins)

Keratella sp. nov. (aff. australis grp)

Keratella procurva (Thorpe)

Keratella quadrata (Muller)

Keratella slacki (Berzins)

Keratella tropica (Apstein)

Keratella sp. A

Plationus patulus (Muller)

Platyias quadricomis Ehrenberg

Asplanchnidae

Asplanchna brightwelli (Gosse)

Asplanchna sieboldi (Leydig)

Asplanchna sp. nov. (aff. sieboldi)

Asplanchna sp. B

Notommatidae

Cephalodella gibba (Ehrenberg)

Eosphora aff. anthadis Harring \&

Myers

Eosphora najas Ehrenberg

Notomamta aff. copeus (Ehrenberg)

Notomamta aff. tripus Ehrenberg

Notommatidae sp. A

Synchaetidae

Polyarthra dolichoptera Idelson

Proalidae

Proales sigmoidea (Skorikov)

Trichocercidae

Trichocerca pusilla Jennings

Trichocerca similis (Wierzejski)

Trichocerca similis grandis (Hauer)

Trichocerca sp.

Dicranophoridae

Dicranophorus epıcharis Harring \&

Myers

Lecanidae

Lecane grandis (Murray)

Lecane hornemanni (Ehrenberg)

Lecane luna (Mueller)

Lecane bulla Gosse

Lecane papuana (Murray)

Lecane thalera (Harring \& Myers)

Lecane ungulata (Gosse)

Lecane sp. B

Lecane sp. C

Euchlanidae

Euchlanis dilatata Ehrenberg

Euchlanis sp. nov.

Euchlanis sp. B

Mytilinidae

Mytilina ventralis macracantha

(Gosse)

Trichotriidae

Macrochaetus collinsi (Gosse)

MOLLUSCA

BIVALVIA

Bivalvia sp.

VENEROIDA

Laternulidae

Laternula aff. anatina (Linnaeus)

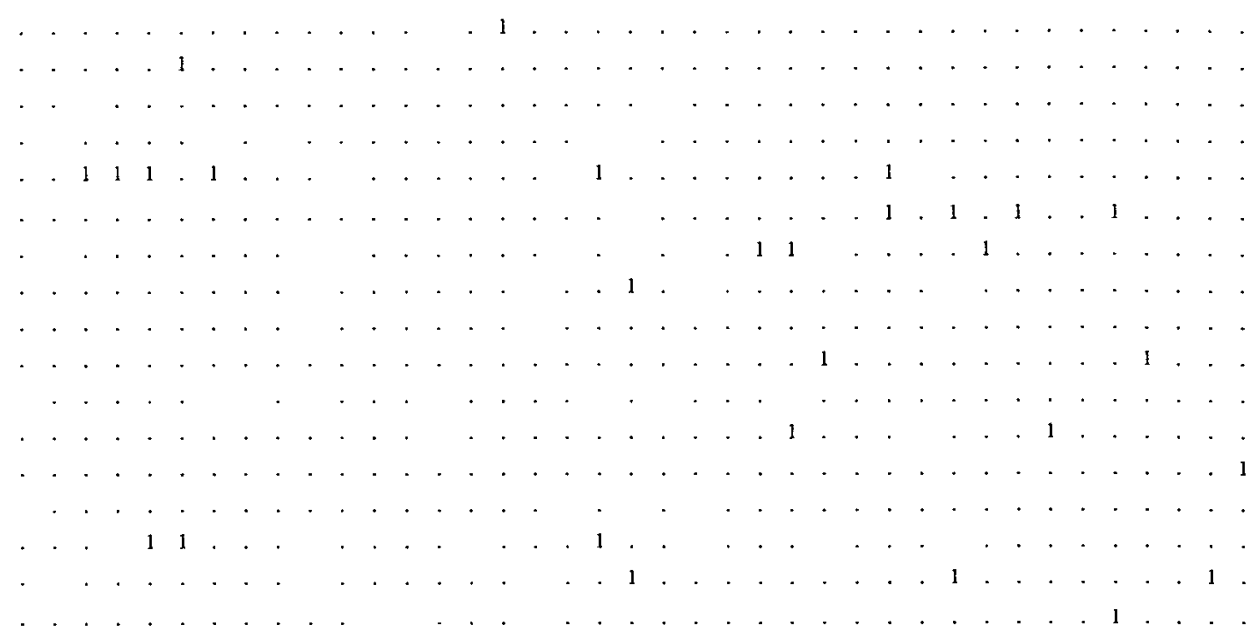


CB58dw

CB58ew

CB62s

CB62w

CB62as

CB62aw

CB62bs

CB62cw

CB67as

CB67aw

CB67bs

CB67bw

CB68w

CB70bs

CB70bw

CB73s

CB73w

CB75aw

CB75aw
CB75bs

CB75bw

CB75cw

CB76s

CB76w

CB77s

CB77w

CB78w

CB79s

CB79w

CB82s

CB82w

CB93s

CB93w

CB93as

CB93aw

CB93cs

CB93cw

CB93ds

CB93dw

CB93fs

CB93fw

CB93gw 


\section{GASTROPODA}

NEOTAENIOGLOSSA

Truncattidae

Truncatella aff. guerinii Villa \&

Villa

Bithyniidae

Gabbia sp. A

Gabbia sp. B

Marginellidae

Marginellidae sp.

OPISTHOBRANCHIA

Scaphandridae

Acteocina sp.

Diaphanidae

?Diaphanidae sp.

BASOMMATOPHORA

Planorbidae

?Glytophysa sp.

Gyraulus sp.

Isidorella newcombi (Adams \&

Angas)

Isidorella sp. B

?Leichardtia sp.

Lymnaeidae

Austropeplea lessoni (Deshayes)

ANNELIDA

POLYCHAETA

PHYLLODOCIDA

Nereidae

Nereidae sp.

Polynoidae

Polynoidae sp.

CAPITELLIDA

Capitellidae

Capitellidae sp.

ORBINIIDA

Orbinilidae

Orbiniidae sp

OLIGOCHAETA

TUBIFICIDA

Enchytraeidae

Enchytraeidae sp.

Tubificidae

Tubificidae sp.

Naididae

Allonais pectinata (Stepenson)

Dero furcata (Muller)

Dero nivea Aiyer

Dero sp.

Nais sp. CB1

Nais sp.

Pristinella jenkinae (Stephenson)

Pristina longiseta Ehrenberg

Pristina sp.

OPISTHOPORA

Opisthopora sp.

. HIRUDINAE

Hirudinae sp. H1

ARTHROPODA

ARACHNIDA

HYDRACARINA

Hydracarina sp.

Hydrachnidae

Hydrachna approximata Halik

Hydrachna sp. 
CB62cw

CB67as

CB67aw

CB67bs

CB67bw

CB68w

CB70bs

CB70bw

CB70b

CB73s

CB73W

CB75as

CB75aw

CB75bs

CB75bw

CB75cw

CB76s

CB76w

CB77s

CB77w

CB78w

CB79s

CB79w

CB82s

CB82w

CB93s

CB93s

CB

CB93

CB93aw

CB93cs

CB93cw

CB93ds

CB93dw

CB93fs

CB93fw

CB93gw

Total 
Eylaidae

Eylais sp.

Hydrodromidae

Hydrodroma sp.

Limnesiidae

Limnesia aff. australica Lundblad

Hygrobatidae

Coaustraliobates longipalpis

(Lundblad)

Corticacarus sp.

Unionicolidae

Recifella sp.

Unionicola aff. lundbladi K.O. Viets

Pionidae

Piona australica K.O. Viets

Piona cumberlandensis (Rainbow)

Aturidae

Albia aff. rectifrons $\mathrm{K}$.Viets

Arrenuridae

Arrenurus balladoniensis Halik

Arrenurus sp. A

Arrenurus sp. B

CRUSTACEA

ANOSTRACA

Branchipodidae

Parartemia informis Linder

Parartemia sp. A

Thamnocephalidae

Branchinella affinis wonganensis

Linder

Branchinella denticulata Linder

Branchinella sp. nov. (aff. lyrifera)

Branchinella occidentalis (Dakin)

Branchinella wellardi Milner

Branchinella probiscida Henry

Brachinella sp. A

NOTOSTRACA

Triopsidae

Triops australiensis australiensis

Spencer \& Hall

CLADOCERA

Sidiidae

Diaphanosoma aff. australiensis

Korovchinsky

Diaphanosoma excisum Sars

Diaphanosoma unguiculatum Gurney

Diaphanosoma sp.

Latonopsis australis Sars

Latonopsis brehmi Petkovski

Sarsilatona aff. papuana (Daday)

Chydoridae

Alonine gen. nov.

Alona cambouei Guerne \& Richard Alona diaphana King

Alona aff. inreticulata Shen et al.

Alona aff. rectangula Sars

Alona rectangula novaezealandiae

Sars

Alona rectangula pulchra Hellich

Alona setuloides Smirnov \& Timms

Alona sp. nov. (aff. A. diaphana

vermiculata)

Alona sp. nov. A

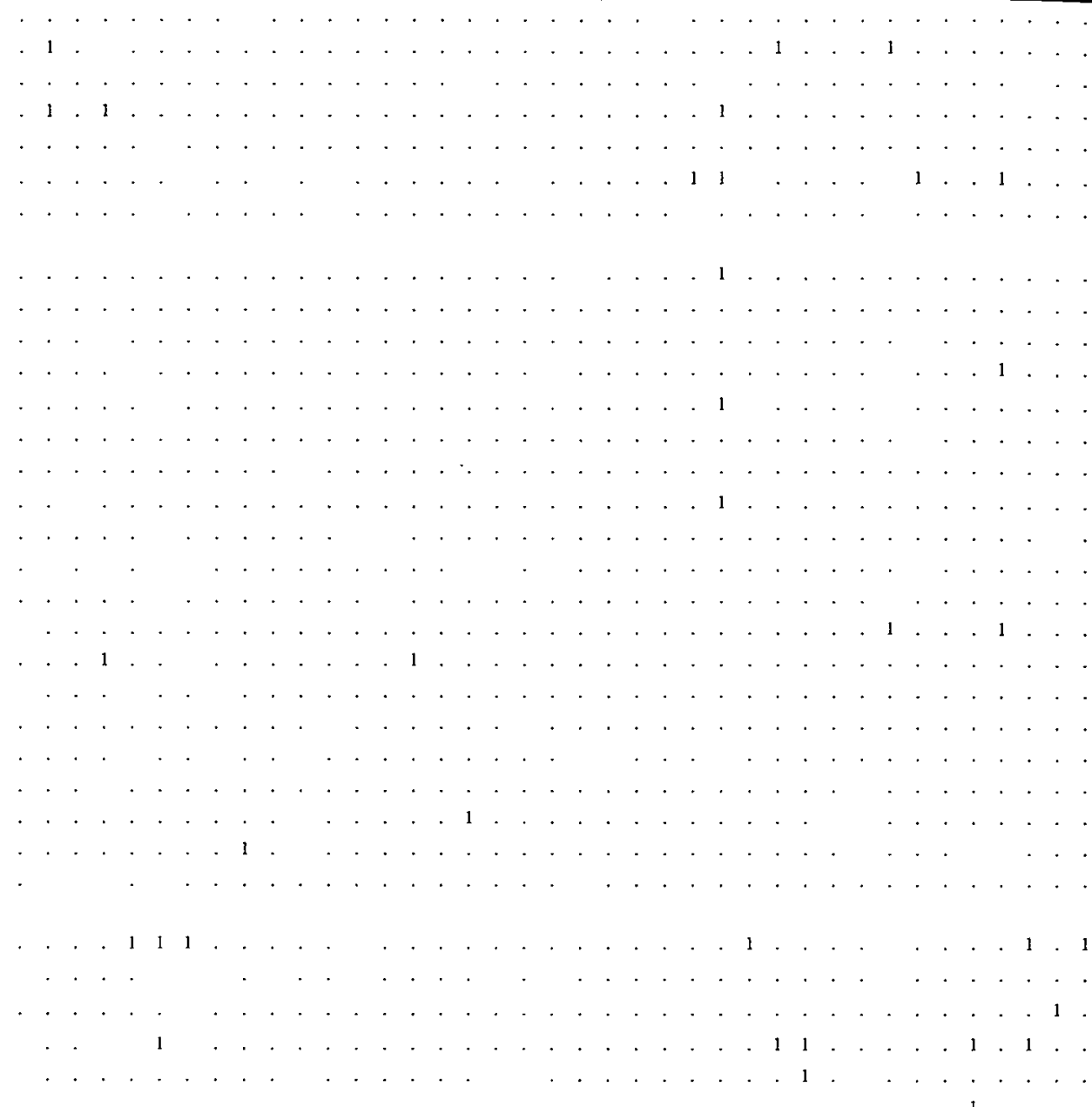


CB68w

CB70bs

CB70bw

CB73s

CB73w

CB75as
CB75aw

CB75bs

CB75bw

CB75cw

CB76s

CB76w

CB77s

CB77w

CB78w

CB79w

CB82s

CB82w

CB93s

CB93w

CB93as

CB93aw

CB93cs

CB93cw

CB93ds

CB93ds

CB93dw

CB93fs

CB93fw

CB93gw
Total 
Alona sp. nov. B

Alona sp. nov. C

Alona sp. nov. D

Alona sp. nov. E

Alona/Biapertura sp. A

Biapertura affinis s.l. (Leydig)

Biapertura aff. longinqua Smirnov

Biapertura aff, macrocopa (Sars)

Biapertura rigidicaudis Smimov

Biapertura aff. rigidicaudis Smirnov

Biapertura sp. nov.

Biapertura sp. B

Biapertura sp. C

Celsinotum hypsilophum Frey

Chydorus eurynotus Sars

Dunhevedia crassa King

Ephemeroporus barroissi Richard

Leydigia aff. acanthocercoides

(Fischer)

Monospilus'diporus Smirnov \&

Timms

Monospilus ' aff. diporus Smirnov \&

Timms

Monospilus' elongatus Smirnov \&

Timms

Planicirclus alticarinatus Frey

Rak sp. nov.

Macrothricidae

Macrothrix breviseta Smirnov

Macrothrix aff. hirsuticornis

Norman \& Brady

Macrothrix aff. spinosa King

Macrothrix sp. nov.

Macrothrix sp. A

Neothrix armata Gurney

Neothrix paucisetosa Smirnov

Neothrix sp. nov. (aff. superarmata)

Neothrix sp.

Moinidae

Moina aff. australiensis Sars

Moina aff. flexuosa Sars

Moina micrura Kurz

Moina mongolica Daday

Moina aff. weismanni Ishikawa

Moina sp. D

Bosminidae

Bosmina meridionalis $\mathrm{S}$ ars

Daphniidae

Ceriodaphnia cornuta Sars

Ceriodaphnia aff. dubia Richard

Ceriodaphnia aff. laticaudata

Mueller

Daphnia angulata Hebert

Daphnia carinata King

Daphnia cephalata King

Daphnia projecta complex Hebert

Daphnia sp. nov. (aff. barbata)

Daphnia sp. nov. (aff. gibba)

Daphnia sp.

Daphniopsis pusilla Serventy

Scapholeberis kingi Sars

Simocephalus aff. heilongjiangensis

Shi \& Shi

Simocephalus vetulus elisabethae

(King)

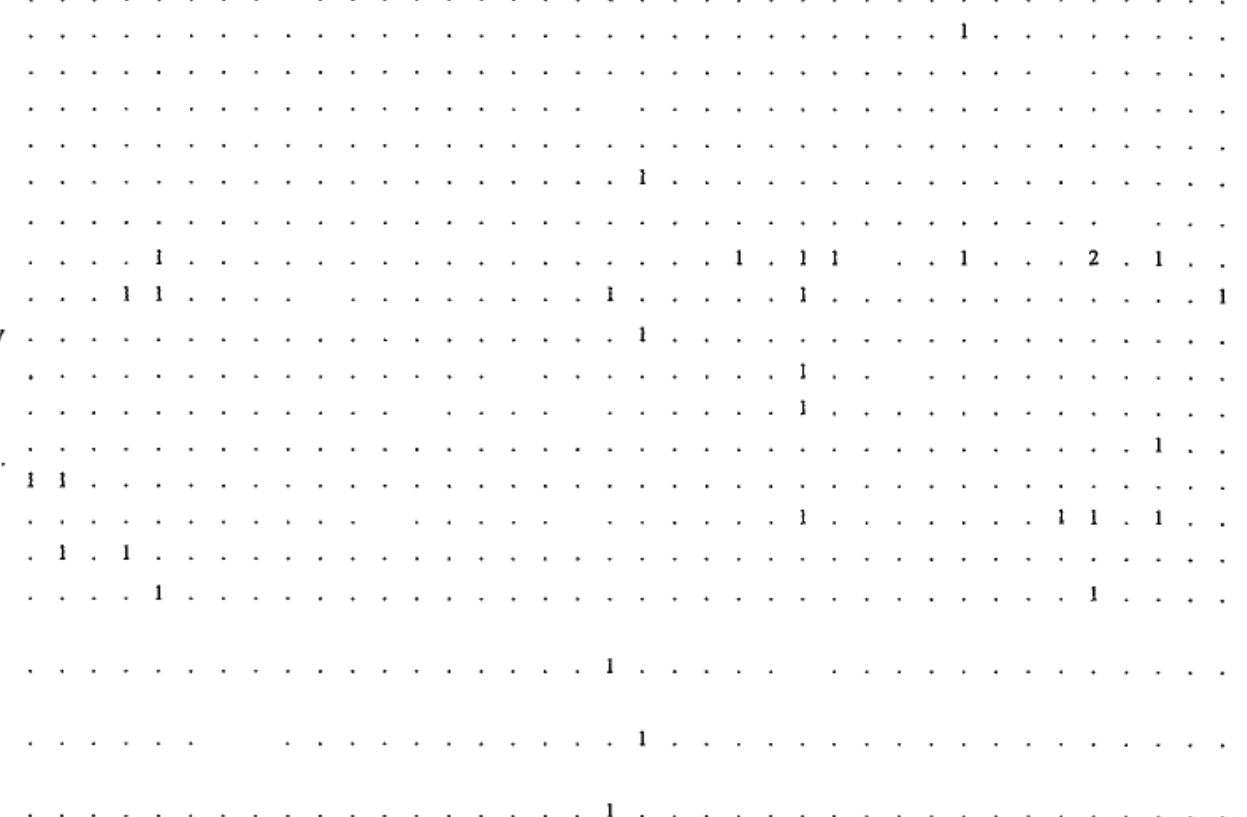


CB56s

CB56w

CB56aw

CB58cw

CB58cw

CB58ew

CB62s

CB62w

CB62as

CB62bs

CB62cw

CB67as

CB67aw

CB67bs

CB67bw

CB67bw
CB68w

CB70bs

CB70bw

CB73s

CB73w

CB75as

CB75bs

CB75bw

CB75cw

CB76s

CB76w

CB77s

CB77w

CB78w

CB79s

CB79w

CB82s
CB82w

CB93s

CB93w

CB93as

CB93aw

CB93cs

CB93cw

CB93ds

CB93dw

CB93fs

CB93 $\mathrm{fw}$

- CB93gw

Total N 
Simocephalus victoriensis Smimov \&

Timms

Simocephalus sp.

Ilyocryptidae

Ilyocryptus sp. nov.

OSTRACODA

Trachyleberididae

Actinocythereis scutigera (Brady)

Cytherideidae

Cyprideis australiensis Hartmann

Paradoxostomatidae

Paradoxostoma sp.

Pectocytheridae

Mckenzieartia portjacksonenesis

(McKenzie)

Darwinulidae

Darwinula sp.

Candonidae

Phlyctenophora aff. zealandia

(Brady) sensu Hartmann

Limnocytheridae

Limnocythere dorsicula De Deckker

Limnocythere porphyretica De

Deckker

Limnocythere aff. porphyretica De

Deckker

Paralimnocythere sp. nov. 275

Paralimnocytherid gen. nov.

Cypridopsidae

Cypridopsis funebris Brady

Sarscypridopsis aculeata (Costa)

Ilyocyprididae

Ilyocypris australiensis Sars

Ilyocypris perigundi De Deckker

Cyprididae

Alboa worooa De Deckker

Ampullacypris sp. nov. 469

?Ampullacypris sp. nov. 498

Australocypris insularis (Chapman)

Bennelongia sp. nov. 414\#

Bennelongia australis (Brady)

.

Bennelongia barangaroo De Deckker

Bennelongia sp.

Candonocypris novaezelandiae

(Baird)

Cypericercus salinus De Deckker

Cypericercus sp. nov. 415

Cypericercus sp. nov. 422

Cypericercus ?sp. nov. 444

Cypretta baylyi McKenzie

Cypretta sp. 488

Cyprinotus kimberleyensis

McKenzie

Cyprinotus edwardi McKenzie

Diacypris dietzi (Herbst)

Hemicypris megalops Sars sensu

McKenzie

?Herpetocypris sp.

Heterocypris tatei (Brady)

Heterocypris aff. vatia De Deckker

Heterocypris sp. nov. 489

Heterocypris sp.

Ilyodromus amplicolis De Deckker 
CB58bw

CB58cw

CBSodw

CB58ew

CB62s

CB62w
CB62as

CB62aw

CB62bs

CB62cw

CB67as

CB67aw

CB67bs

CB67bw

CB68w

CB70bs

CB70bw

CB73s

CB73w

CB75as

CB75aw

CB75bs

CB75bw

CB75cw

CB76s

CB76w

CB77s

CB77w

CB78w

CB79s

CB79w

CB25

CB82w

CB93s

CB93w

CB93as

CB93aw

CB93cs

CB93cw

CB93ds

CB93dw

CB93fs

CB93fw

CB93gw

Total 
Ilyodromus candonites De Deckker

Ilyodromus dikrus De Deckker

Ilyodromus aff. viridulus (Brady)

Ilyodromus sp. nov. 255

Mytilocypris mytiloides (Brady)

Mytilocypris sp. nov. 426

Trigonocypris aff. globosa De

Deckker

Newnhamia fenestra King

Reticypris pinguis De Deckker

Strandesia aff. phoenix De Deckker

Zonocypris sp. nov. 466

Zonocypretta kalimna De Deckker

CONCHOSTRACA

Lynceidae

Lynceus sp. A

Limnadiidae

Limnadopsis sp.

Limnadia sp. A

Cyzicidae

Cyzicus sp. A

Cyzicus sp. B

Cyzicus sp. C

Cyzicus sp. D

Cyzicus sp. E

Cyzicus sp. F

Cyzicus sp. $\mathrm{H}$

Cyzicus sp. I

Cyzicus sp.

CALANOIDA

Acartiidae

Acartia sp. 357

Centropagidae

Boeckella triarticulata (Thomson)

Calamoecia halsei Bayly

Calamoecia ampulla (Carnarvon

form) (Searle)

Calamoecia canberra Bayly

Calamoecia clitellata Bayly

Calamoecia sp. nov. (aff. lucasi Cue

form)

Calamoecia tasmanica subattenuata

(Fairbridge)

Calamoecia sp.

Diaptomidae

Eudiaptomus lumholtzi Sars

Cyclopoidae

Apocyclops dengizicus (Lepechkine) Australocyclops similis Morton

Ectocyclops rubrescens Brady

Halicyclops sp. 376

Mesocyclops spp.

Metacyclops arnaudi sensu Kiefer

Metacyclops arnaudi (Sars)

Metacyclops sp. CB2

Metacyclops sp. CB4

Microcyclops varicans (Sars)

Microcyclops sp. CB2

Neocyclops petovskii De Laurentiis

et al.

Thermocyclops decipiens (Kiefer)

HARPACTICOIDA

Canthocamptidae

Mesochra flava Lang 
CB58bw

CB58cw

CB58dw

CB5ew

CB62s

CB62w
CB62as

CB62aw

CB62bs

CB62cw

CB67as

CB67aw

CB67bs

CB67bw
CB68w

CB70bs

CB70bs
CB70bw

CB70b

CB73s

CB75

CB75as

CB75aw
CB75bs

CB75bw

CB75cw

CB76s

CB76w

CB77s

CB77w

CB79s

CB79w

CB82s

CB82s

CB82w

CB93s

CB93w

CB93as

CB93aw

CB93cs

CB93cw

CB93ds

CB93dw

CB93fs

CB93fw

CB93gw

Total 
Cletocamptus confluens (Schmeil)

Cletocamptus dietersi (Richard)

Nannomesochra arupinensis (Brian)

Laophontidae

Heterolaophonte oculata (Gurney)

Onychocamptus bengalensis (Sewell)

Quinquelaophonte wellsi (Hamond)

Ameiridae

Ameira sp. 308

Aff. Ameira sp.

Nitocra affinis Gumey

Diosaccidae

Amonardia sp. nov.

Amphiascoides subdebilis (Willey)

Amphiascopsis cinctus (Claus)

Bulbamphiascus imus (Brady)

Robertsonia mourei (Nogueira)

Robertsonia propinqua (Scott)

Robertsonia sp. A

Diossacidae sp.

Tisbidae

Tisbella timsae Gumey

Thalestridae

Eudactylopus sp.

Louriniidae

Lourinia armata (Claus)

ISOPODA

Sphaeromatidae

Sphaeromatidae sp

AMPHIPODA

Paracalliopiidae

Paracalliopiidae sp. A1

Paramelitidae

Paramelitidae sp. A4

Ceinidae

Ceinidae sp. A2

Ceinidae sp. A3

DECAPODA

Decapoda sp. M1

INSECTA

EPHEMEROPTERA

\section{Caenidae}

Tasmanocoenis sp. ARR J or M

Baetidae

Cloeon sp.

Baetidae genus 1 WA sp. 2

ZGYOPTERA

\section{Coenagriidae}

Austroagrion coeruleum (Tillyard)

Ischnura aurora (Brauer)

Ischnura heterosticta (Burmeister)

Xanthagrion erythroneurum Selys

Megapodagrionidae

Argiolestes pusillus Tillyard

Lestidae

Austrolestes annulosus (Selys)

Austrolestes aridus (Tillyard)

Austrolestes io (Selys)

ANISOPTERA

Gomphidae

Austrogomphus gordoni Watson

Aeshnidae

Aeschna brevistyla Rambur

Hemianax papuensis (Burmeister)

\section{$1.11 \ldots . . . . .1$}

. . . .

$\cdot$

1

. . . . . . 111. 
CB62bs

CB62cw
CB67as

CB67aw

CB67aw

CB67bs

CB67bw

CB68w
CB70bs

CB70bw

CB73s

CB73w
CB73w

CB75as

CB75aw

CB75bs

CB75bw

CB75cw

CB75cw

CB76s

CB76w

CB77

CB77w

CB79s

CB79w

CB82s

CB82w

CB93s

CB93w

CB93as

CB93aw

CB93cs

CB93cw

CB93ds

CB93dw

CB93fs

CB93fw

CB93gw 


\section{Corduliidae}

Hemicordulia tau Selys

Procordulia affinis (Selys)

Libellulidae

Austrothemis nigriscens (Martin)

Diplacodes bipunctata (Brauer)

Diplacodes haematodes (Burmeister)

Orthetrum caledonicum (Brauer)

Pantala flavescens (Fabricius)

Trapezostigmata stenoloba Watson

Libellulidae sp.

HEMIPTERA

Saldidae

Pentacora sp.

Saldula sp. A

Saldula sp. B

Gerridae

Limognogonus fossarum gilguy

Anderson \& Weir

Limnogonus sp.

Veliidae

Microvelia oceanica Distant

Microvelia peramoena Hale

Microvelia sp.

Mesoveliidae

Mesovelia vittigera Horvath

Mesovelia sp.

\section{Corixidae}

Agraptocorixa eurynome (Kirkaldy) Agraptocorixa hirtifrons (Hale)

Agraptocorixa parvipunctata (Hale)

Agraptocorixa sp.

Micronecta annae s.l. (Kirkaldy)

Micronecta gracilis Hale

Micronecta robusta Hale

Micronecta ? halei Wroblewski

Micronecta sp. A

Micronecta sp.

Sigara mullaka Lansbury

Belostomatidae

Diplonychus eques (Dufour)

Lethocerus distinctifemur Menke

Notonectidae

Anisops calcaratus Hale

Anisops gratus Hale

Anisops hackeri Brooks

Anisops nabilla Lansbury

Anisops nasuta Fieber

Anisops stali Kirkaldy

Anisops thienemanni Lundblad

Anisops sp. A

Anisops sp.

Pleidae

Plea sp. nov.

DIPTERA

Tipulidae

Tipulidae sp.

Simuliidae

Simulium ornatipes Skuse

Simuliidae sp.

Culicidae

Aedes camptorhynchus (Thomson)

Aedes sp. ENM 71

Anopheles annulipes s.l. Walker

sensu Liehne

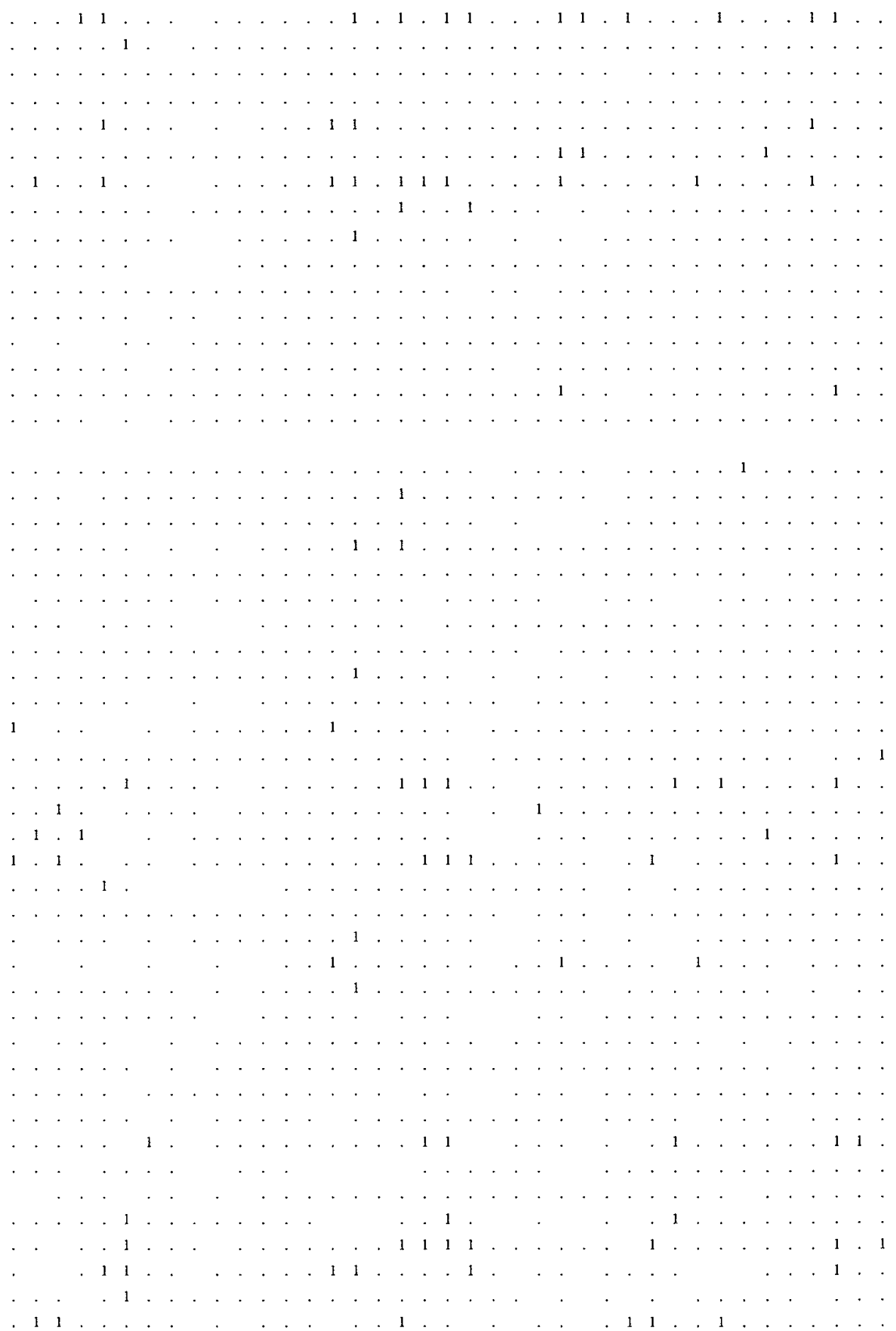


CB58cw

CB58dw

CB58ew 
Anopheles sp.

Culex annulirostris Skuse

Culex australicus Dobrotworsky \&

Drummond

Culex sp.

Chaoboridae

Chaoboridae sp.

Pyschodidae

Psychodidae sp.

Chironomidae

Cricotopus sp. $\mathrm{CBO} 9$

? Limnophyes pullulus (Skuse)

Nanocladius sp. CBO1

Parakieffiella sp. CBO5

Parametriocnemus? Ornaticornis

Kieffer sensu Cranston

?Parametriocnemus sp. $\mathrm{CBO} 4$

Rheocricotopus sp. CBO6

Orthocladiinae ?gen. ?sp. $\mathrm{CBO} 2$

Orthocladiinae ?gen. ?sp. $\mathrm{CBO} 8$

Ablabesmyia spp.^

Coelopynia pruinosa Freeman

Larsia? albiceps (Johannsen)

Paramerina sp. CBT5

Paramerina sp. CBT7

Procladius spp. CBT1!

Chironomus aff. alternans Walker

Chironomus tepperi Skuse

Cladopelma curtivalva Kieffer

Cladotanytarsus sp. $\mathrm{CBC} 27$

Cladotanytarsus sp. $\mathrm{CBC} 2$

Cryptochironomus griseidorsum

Kieffer

Dicrotendipes sp. $\mathrm{CBC} 13$

Dicrotendipes jobetus Epler

? Harnischia sp. CBC21

Kiefferulus intertinctus Skuse

Paraborniella sp. CBC14

Parachironomus sp. CBC22

Paracladopelma sp. CBC15

Paratendipes sp. $\mathrm{CBC} 24$

Polypedilum watsoni Freeman

Polypedilum leei Freeman

Polypedilum nubifer (Skuse)

Rheotanytarsus? juliae Glover sensu

Cranston

? Sttctochironomus sp. CBC26

Tanytarsus barbitarsus Freeman

Tanytarsus sp. $\mathrm{CBC} 16$

Tanytarsus sp. CBC3

Chironomini ?gen. ?sp. CBC9

Ceratopogonidae

Forcipomyinae sp.

Culicoidinae sp.

Palpomyinae sp.

Ceratopogonidae sp. A

Ceratopogonidae sp. B

Ceratopogonidae sp. C

Ceratopogonidae sp. D

Ceratopogonidae sp. E

Ceratopogonidae sp.

Stratiomydidae

Stratiomyidae sp.

Tabanidae

Tabanidae sp. A 
CB56w

CB56aw

CB58bw

CB58cw

CB58dw

CB58ew

CB62s

CB62w

CB62aw

CB62bs

CB62cw
CB67as

CB67as
CB67aw

CB67aw
CB67bs

CB67bw

CB68w

CB70bs

CB70bw

CB73s

CB73w

CB75as

CB75aw

CB75bs

CB75bw

CB75cw

CB76s

CB76w
CB77s

CB77s
CB77w

CB78w

CB79s

CB79w

CB82s

CB82w

CB93s

CB93w

CB93as

CB93aw

CB93cs

CB93cs

CB93cw

CB93ds
CB93dw

CB93dw

CB93fs

CB93fw

CB93gw

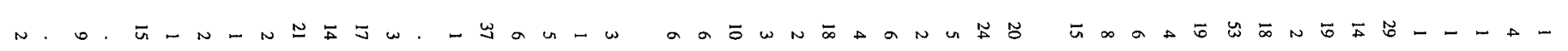

Total 
Tabanidae sp. B

Dolichopodidae

Dolichopodidae sp.

Empididae

Empididae sp.

Sciomyzidae

Sciomyzidae sp.

Ephydridae

Ephydridae sp. A

Ephydridae sp. B

Ephydridae sp. C

Ephydridae sp. D

Ephydridae sp. E

Muscidae

Muscidae sp.

LEPIDOPTERA

Pyralidae

Pyralidae spp.

TRICHOPTERA

Hydroptilidae

Acritoptila globosa Wells

Hellyethira sp.

Ecnomidae

Ecnomus sp.

Leptoceridae

Notalina fulva Kimmins

Oecetis sp. AV6

Oecetis sp. AV28

Triplectides australis Navas

COLEOPTERA

Coleoptera sp. C

Haliplidae

Haliplus fuscatus Clark

Haliplus testudo Clark

Gyrinidae

Dineutus australis (Fabricius)

Dytiscidae

Allodessus bistrigatus (Clark)

Allodessus sp.

Antiporus femoralis (Boheman)

Copelatus irregularis Macleay

Cybister tripunctatus (Olivier)

Eretes australis (Erichson)

Homeodytes scutellaris (Germar)

Hydroglyphus daemali (Sharp)

Hydroglyphus leai (Guignot)

Hydrovatus opacus (Sharp)

Hyphydrus elegans (Montrouzier)

Laccophilus sharpi Regimbart

Macroporus/Megaporus sp.

Necterosoma penicillatus (Clark)

Necterosoma regulare Sharp

Necterosoma sp.

Paroster sp. nov.

Platynectes decempunctatus

(Fabricius)

-Platynectes sp.

Rhantus suturalis W.S. MacLeay

Sternopriscus multimaculatus (Clark)

Tiporus tambreyi Watts

Tiporus sp. nov.

Uvaris pictipes (Lea)

Dytiscidae sp.

Hydraenidae

Hydraena sp.

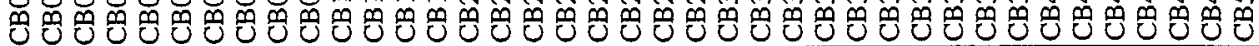

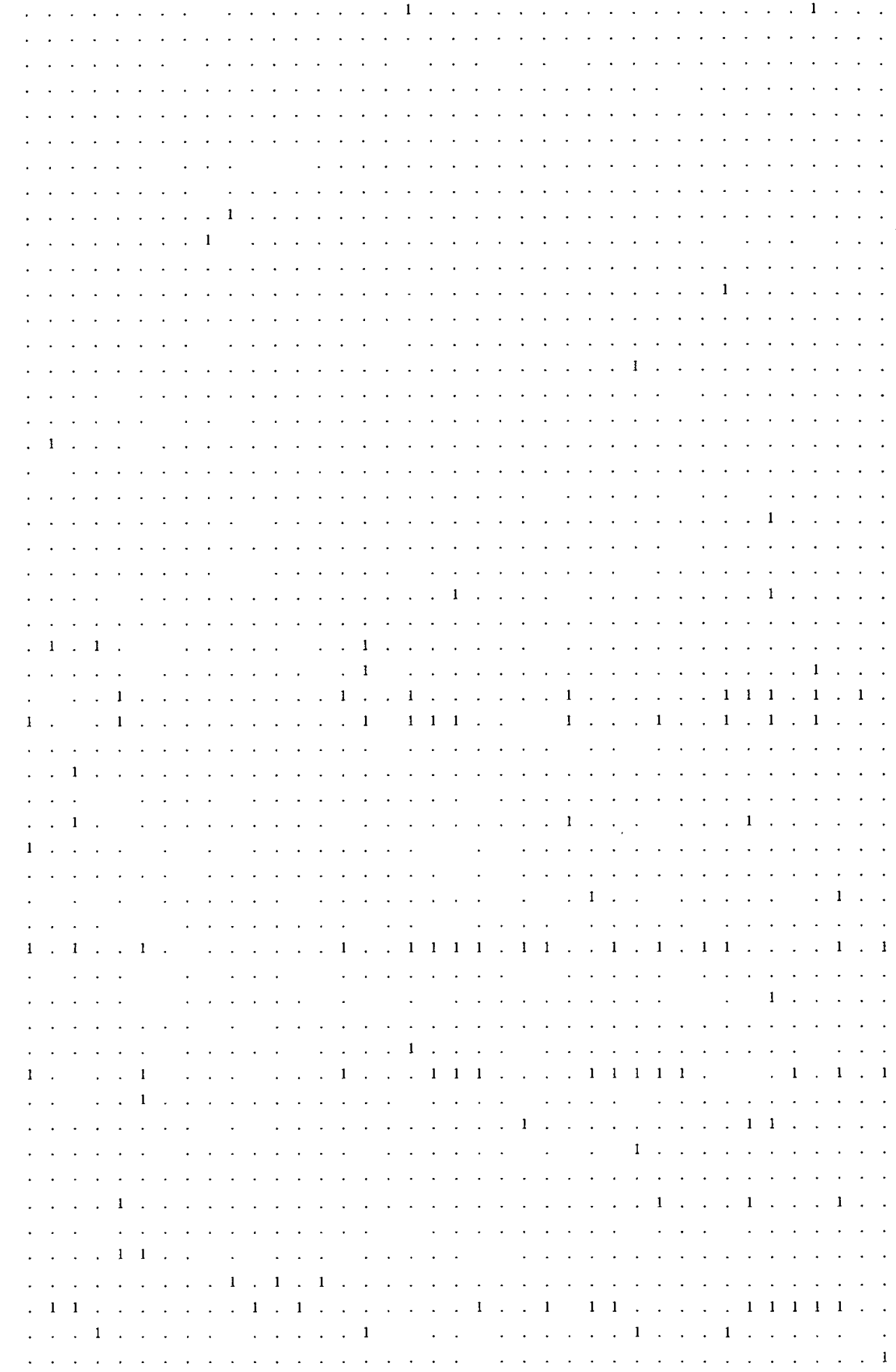


CB58ew

CB62s

CB62w

CB62as

CB62aw

CB62bs

CB62cw

CB67as

CB67aw

CB67bs
CB67bw

CB68w

CB70bs

CB70bw

CB73s

CB73w
CB75as

CB75aw

CB75bs

CB75bw

CB75cw

CB76s

CB76w

CB77s

CB77w

CB78w

CB79s

CB79w

CB82s

CB82w

CB93s

CB93w
CB93as

CB93aw

CB93cs

CB93cw

CB93ds

CB93dw

CB93fs

CB93fw

CB93gw

Tota 
Ochthebius sp.

Hydraenidae sp.

Hydrochidae

Hydrochus sp.

Hydrophilidae

Berosus approximas Fairmaire

Berosus dallasae Watts

Berosus munitipennis Blackburn

Berosus nutans (W. MacLeay)

Berosus sp.

Enochrus deserticola (Blackburn)

Enochrus elongatus (W. MacLeay)

Enochrus sp. C

Helochares percyi Watts

Hydrophilus brevispina Fairmaire

Laccobius zietzi Blackburn

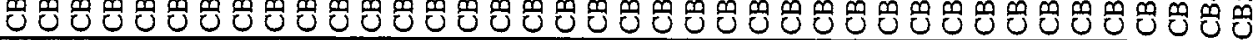

Limnoxenus zealandicus (Broun)

Paracymus pygmaeus (W. MacLeay)

Paracymus spenceri (Blackburn)

Sternolophus immarginatus

d'Orchymont

Hydrophilidae sp.

Curculionidae

Curculionidae sp. A

Curculionidae sp. D

Curculionidae sp. F

Curculionidae sp.

Chrysomelidae sp.

Anthicidae

Anthicidae sp.

Helodidae

Heterocerus delibipes (Blackburn)

Helodidae sp.

Limnichidae

Limnichidae sp.

Brentidae

Brentidae sp.

No of species

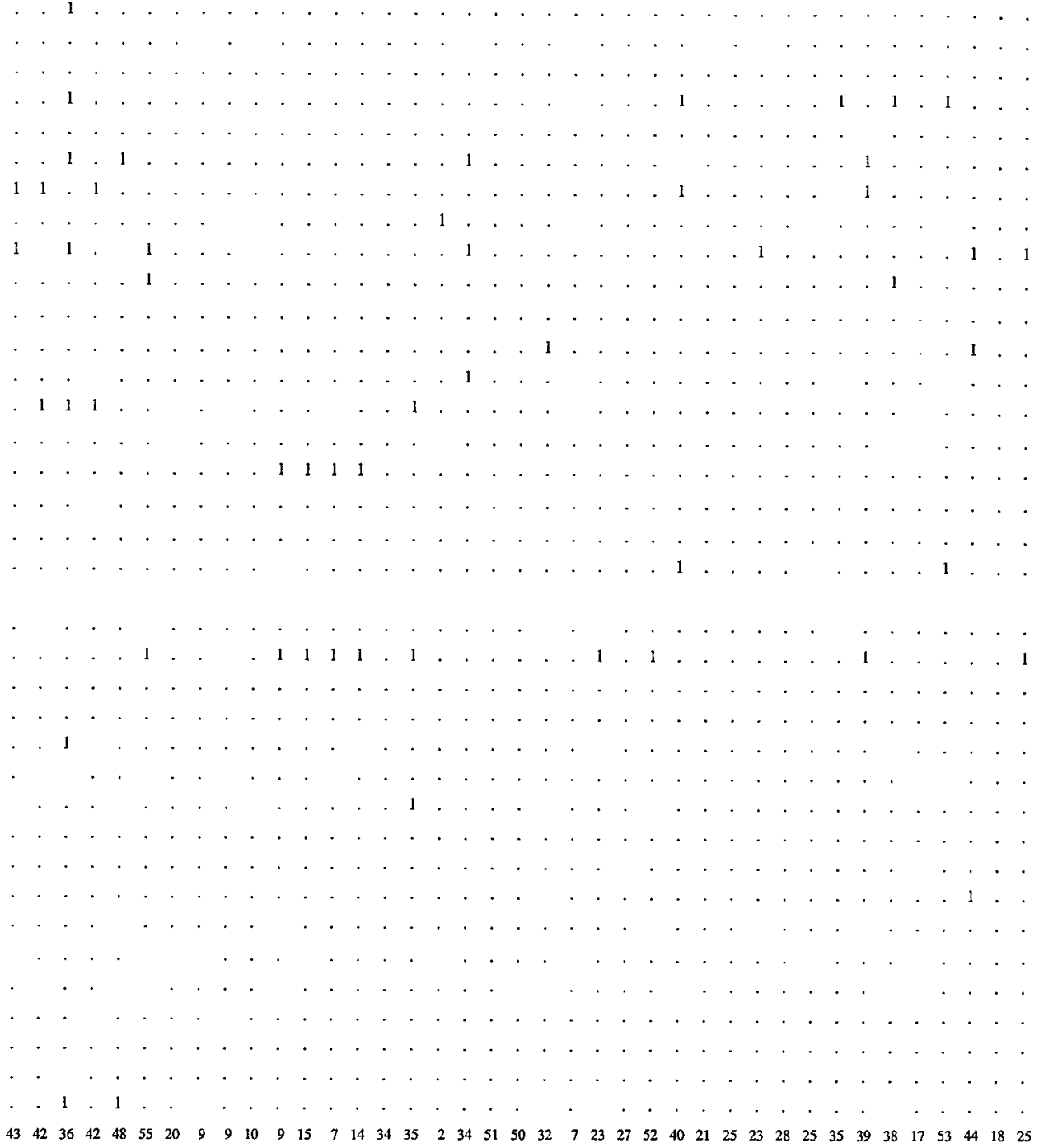

** Dapnia projecta and $D$. sp. nov. (aff. pojecta) were not separated

\# Bennelongia sp. nov. 414 consisted of a winter and a less common summer form

$\wedge$ Mesocyclops brooksi (predominantly), Mesocyclops australiensis (Sars) and Mesocyclops sp. nov. were not separated

^ Ablabesmyia spp. consisted of A. notabilis Skuse and, sometimes, A. hilli Freeman

! Procladius spp. consisted of $P$. paludicola Skuse and, less frequently, a smaller species of Procladius 


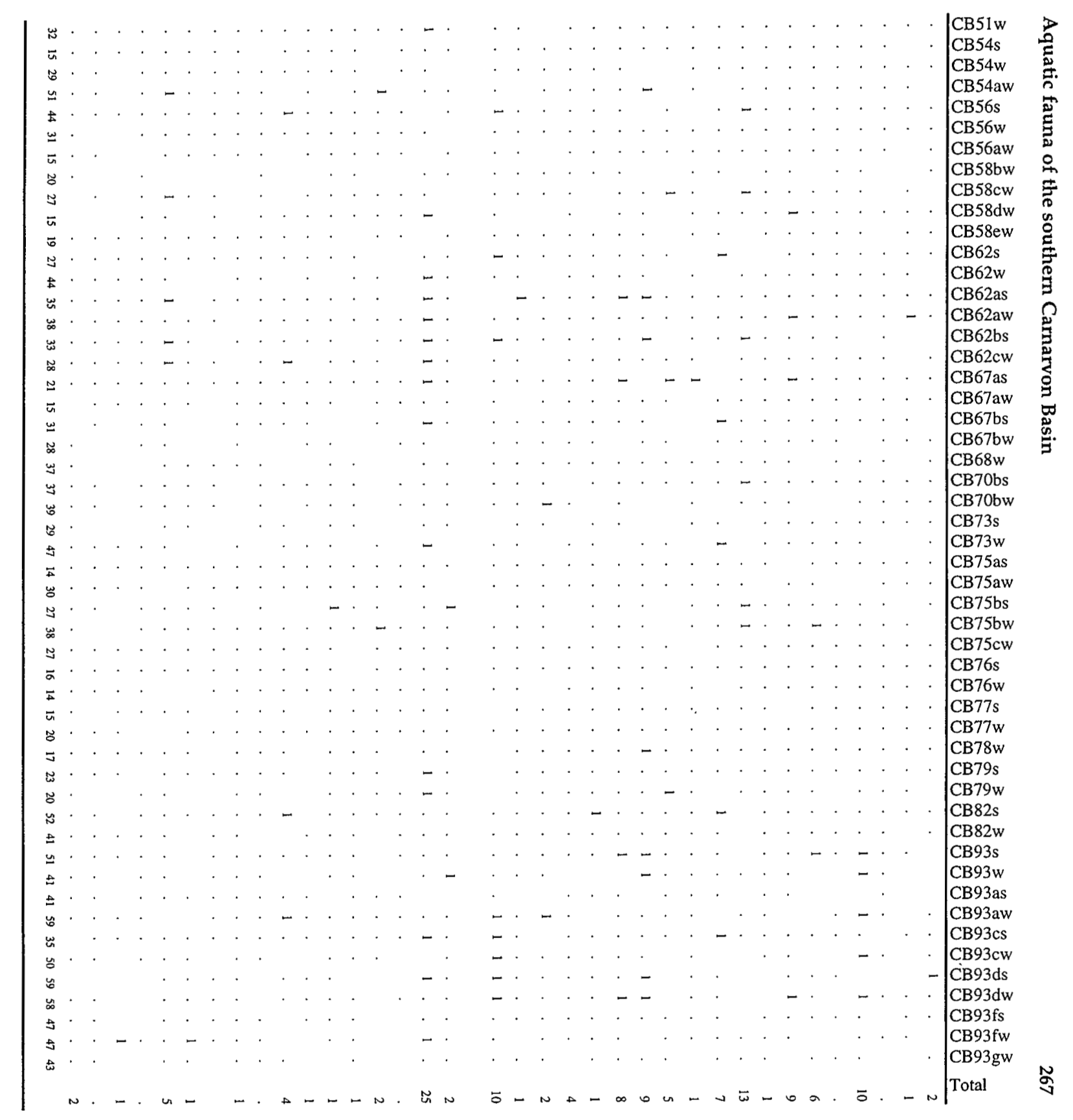

